\title{
Geothermal Energy Prospects for the Next 50 Years
}

\author{
ER-611-SR \\ Special Report, February 1978 \\ Preliminary Report \\ to the \\ Conservation Commission \\ WORLD ENERGY CONFERENCE
}

Electric Power Research Institute

3412 Hillview Avenue

Palo Alto California 94304

EPRI Program Manager

Vasel W. Roberts

Fossil Fuel and Advanced Systems Division 


\section{DISCLAIMER}

This report was prepared as an account of work sponsored by an agency of the United States Government. Neither the United States Government nor any agency Thereof, nor any of their employees, makes any warranty, express or implied, or assumes any legal liability or responsibility for the accuracy, completeness, or usefulness of any information, apparatus, product, or process disclosed, or represents that its use would not infringe privately owned rights. Reference herein to any specific commercial product, process, or service by trade name, trademark, manufacturer, or otherwise does not necessarily constitute or imply its endorsement, recommendation, or favoring by the United States Government or any agency thereof. The views and opinions of authors expressed herein do not necessarily state or reflect those of the United States Government or any agency thereof. 


\section{DISCLAIMER}

Portions of this document may be illegible in electronic image products. Images are produced from the best available original document. 
This report was prepared by the Electric Power Research Institute (EPRI). Neither EPRI, members of EPRI, nor any person acting on behalf of either: (a) makes any warranty or representation, express or implied, with respect to the accuracy, completeness, or usefulness of the information contained in this report, or that the use of any information, apparatus, method, or process disclosed in this report may not infringe privately owned rights; or (b) assumes any liabilities with respect to the use of, or for damages resulting from the use of, any information, apparatus, method, or process disclosed in this report. 


\section{ABSTRACT}

The material in this report was compiled for use in a report on unconventional energy resources prepared by the Conservation Commission of the World Energy Conference (WEC). Because of the necessity for brevity in the WEC report, much of the material was condensed. This report is being published for the benefit of those who may wish more detailed information.

Three facets of geothermal energy--resource base, electric power potential, and potential nonelectric uses--are considered, using information derived from three sources: (1) analytic computations based on gross geologic and geophysical features of the earth's crust, (2) the literature, and (3) a worldwide questionnaire. None of these sources either individually or in combination fully satisfy the need for information about the geothermal potential, but it is hoped that a more comprehensive assessment can be evolved as more data become available. 


\section{ACKNOWLEDGMENTS}

The Electric Power Research Institute wishes to acknowledge the information that was graciously provided by many nations in response to our questionnaire and to express our appreciation to those countries and individuals who participated.

The Institute also wishes to acknowledge the contributions provided by Paul Kruger and A. Louis London, Stanford University; Tsvi Meidav and Subir Sanyal, Geonomics, Inc.; and Gordon Reistad, Oregon State University. 


\section{CONTENTS}

\begin{tabular}{|c|c|c|}
\hline Section & & $\underline{\text { Page }}$ \\
\hline 1 & INTRODUCTION & $1-1$ \\
\hline \multirow[t]{4}{*}{2} & GEOTHERMAL RESOURCES & $2-1$ \\
\hline & Geothermal Energy Resource Types & $2-1$ \\
\hline & Geographic Distribution of Geothermal Resources & $2-3$ \\
\hline & Geothermal Resource Base & $2-5$ \\
\hline \multirow[t]{5}{*}{3} & ELECTRICAL ENERGY CONVERSION & $3-1$ \\
\hline & Electric Power Potential & $3-2$ \\
\hline & Estimated World Potential for Geothermal Electricity & $3-10$ \\
\hline & Projected Utilization & $3-15$ \\
\hline & Economics of Geothermal Power & $3-15$ \\
\hline \multirow[t]{6}{*}{4} & NONELECTRIC USES & $4-1$ \\
\hline & Present Uses & $4-1$ \\
\hline & Potential Uses & $4-13$ \\
\hline & Problems in Nonelectric Uses & $4-14$ \\
\hline & Economics & $4-19$ \\
\hline & Outlook for the Future & $4-20$ \\
\hline \multirow[t]{9}{*}{5} & RECENT INTERNATIONAL DEVELOPMENTS & $5-1$ \\
\hline & North America & $5-1$ \\
\hline & Central America & $5-4$ \\
\hline & South America & $5-6$ \\
\hline & Western Europe & $5-7$ \\
\hline & Eastern Europe & $5-11$ \\
\hline & Asia & $5-13$ \\
\hline & East Africa & $5-15$ \\
\hline & Oceania & $5-16$ \\
\hline 6 & ENVIRONMENTAL CONSIDERATIONS & $6-1$ \\
\hline 7 & BIBLIOGRAPHY & $7-1$ \\
\hline
\end{tabular}


$\bullet$

$\theta$ 


\section{ILLUSTRATIONS}

\section{Figure}

Page

1 Geothermal Regions of the World

2 Geothermal Reservoir Thermodynamics

3 Available Energy Fraction, $F_{a}$

4 Available Fraction As a Function of Initial and Final Reservoir Temperatures

5 Available Energy Fraction As a Function of Reservoir Sink Temperatures

6 Approximate Geothermal Fluid Temperatures for Nonelectric Applications

7 Locations of Geothermal Drilling in the United States and Northern Mexico

8 Geothermal Regions of Italy

9 Major Geothermal Areas of Japan 
1 Worldwide Geothermal Energy Use xii

2 Worldwide Geothermal Resource Base xiii

3 Calculated Worldwide Geothermal Resource Base 2-6

4 Geothermal Resource Base Provided by Countries in
Response to Questionnaires

5 Hydrothermal Electricity Potential 3-11

Electricity Generating Capacity from Geothermal
Resources

7 Present Nonelectric Applications of Geothermal Energy 4-3

8 Energy Requirements in Relation to Product Value for
a Wide Variety of Processes

9 Potential Industrial Uses of Geothermal Energy 4-17

10 Cost for Space Heating With Various Fuels in
Reykjavik, Iceland

Projected Nonelectric Application of Geothermal
Energy (calculated)

12 Projected Nonelectric Applications of Geothermal Energy in the Years 1985, 2000, and 2020 (results from questionnaires) 


\section{SUMMARY}

The penetration of any natural resource into the marketplace is a function of dynamic economic relationships that are sometimes difficult to determine in advance. The concept of reserves is intimately linked to these relationships, where reserve is that portion of the resource base known to exist and to be producible and marketable in competition with other resources. In the case of geothermal energy, neither the reserves nor the resource base is well known at this time. For the purpose of this report the prospects for worldwide geothermal energy utilization were investigated from two approaches. The first was based on projections made by professionals and organizations in various countries of the world, as reported in the literature and as reported in response to the EPRI questionnaire that was sent to member nations of the World Energy Conference and to many nonmember nations. The second approach was to estimate the potential for utilization based on geothermal, geologic, and geophysical parameters and engineering estimates of recovery and conversion efficiencies. The resulting data on potential geothermal energy utilization throughout the world are summarized in tables 1 and 2 .

The geothermal resource base underlying the continental land masses of the world to a depth of $3 \mathrm{~km}$ and at temperatures higher than $15^{\circ} \mathrm{C}$ was calculated to be $1.2 \times 10^{13} \mathrm{GWh}(\mathrm{th})$. The sum of the estimates reported by individual countries was $5.8 \times 10^{11} \mathrm{GWh}(\mathrm{th})$. The difference lies in the gross assumptions of the general method used in the first approach, the general incompleteness of detailed assessments of geothermal potential, and conservative estimates of specific resources in individual nations. Only about $2 \%$ of the resource base is high enough in temperature to be considered for electric power generation, and only about 1 part in 10,000 can be converted to electric energy with present technology. Although the overall recovery and conversion efficiencies are very small, the electric energy potential with current technology is substantial, roughiy $1.2 \times 10^{3} \mathrm{GW}$ cen(e) (gigawatt-centuries, electric). The present worldwide, installed electric-power generating capacity is $1.325 \mathrm{GW}(\mathrm{e})$. 
Table 1

WORLDWIDE GEOTHERMAL ENERGY USE

Source

Literature and
questionnaire
Calculation

1977

1.3

$\stackrel{x}{\exists}$

Electric Capacity (GW)

1985

2000

2020

Not available

1000

Thermal Capacity (GW)

1977

1985

2000

2020

Literature and

questionnaire

7.0

33

76

210

Calculation

25,000

80,000

120,000 
Table 2

\section{WORLDWIDE GEOTHERMAL RESOURCE BASE}

\begin{tabular}{|c|c|c|c|c|c|}
\hline & Class & $\begin{array}{c}\text { Temperature } \\
\left({ }^{\circ} \mathrm{C}\right)\end{array}$ & $\begin{array}{c}\text { Resource Base }{ }^{\mathrm{a}} \\
\text { (GWh [th]) }\end{array}$ & $\begin{array}{c}\text { Thermal } \\
\text { Potential } \\
\text { (GWh [th]) }\end{array}$ & $\begin{array}{c}\text { Electric } \\
\text { Potential } \\
\text { (GWh }[e])\end{array}$ \\
\hline 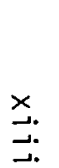 & $\begin{array}{l}1 \\
2 \\
3 \\
4\end{array}$ & $\begin{array}{l}<100 \\
100-150 \\
150-250 \\
>250\end{array}$ & $\begin{array}{r}1.05 \times 10^{13} \\
1.07 \times 10^{12} \\
2.7 \times 10^{11} \\
1.4 \times 10^{10}\end{array}$ & $\begin{array}{l}7.3 \times 10^{11} \\
7.5 \times 10^{10} \\
1.9 \times 10^{10} \\
9.7 \times 10^{8}\end{array}$ & $\begin{array}{c}0 \\
0 \\
4.8 \times 10^{9} \\
2.5 \times 10^{8}\end{array}$ \\
\hline & Totals & & $1.2 \times 10^{13}$ & $8.2 \times 10^{11}$ & $5.1 \times 10^{9}$ \\
\hline
\end{tabular}

${ }^{a}$ Resource base is the energy stored at temperatures above $15^{\circ} \mathrm{C}$ at depths to $3 \mathrm{~km}$. The sum of individual country estimates is $5.8 \times 10^{11} \mathrm{GWh}$ (th).

$b_{\text {It }}$ is assumed that only about $20 \%$ of these quantities can be produced with current technology. 
The potential for nonelectric uses is much greater than the potential for electric power generation in terms of total heat; but the growth of nonelectric applications may be slower than that of electric applications because of the necessity for compatible industries and for populations to be near the resource. However, geothermal energy is a truly international energy resource because it is present in all countries on earth. Thus, it should be carefully considered in the evaluation of alternative energy sources throughout the world. 


\section{Section 1}

INTRODUCTION

Geothermal energy is the natural heat of the earth and is a truly international source of energy, available as an indigenous source of energy in all countries on earth. At present, geothermal energy is being sought primarily for the production of electric power, but its utilization in other forms, such as space and industrial heating, may be of great value in the economy of many nations seeking development of alternative energy sources and conservation of fossil and nuclear fuels.

Geothermal energy has been used for centuries. Early uses included space heating and therapeutic baths (balneology). Current applications include agriculture, municipal and industrial heating, and the generation of electric energy.

Attempts to harness geothermal energy to produce electric power date back to the beginning of this century. The first experimental electric power generator was operated at Larderel10, Italy, in 1904, using natural geothermal steam that seeped through rock fractures to the surface. The first power plant was completed in 1913 in Italy, the pioneer in developing geothermal energy for power generation. In a number of other countries, including Japan, the United States, and Indonesia, attempts to develop geothermal energy for power production were made in the early 1920s. Geothermal energy developments have since occurred in a number of countries, reaching a total world electric capacity of about $1.3 \mathrm{GW}$ in 1976 . However, the incentive for developing geothermal energy was small when fossil fuel was inexpensive and presumed in abundant supply. Furthermore, energy planners have traditionally been reluctant to depend on an energy resource when its quantity could not be precisely predicted or its cost was not known well in advance. After the energy crisis of 1973, when fossil fuel costs rose markediy compared with the period immediately preceding the crisis, a reexamination of all existing energy resources brought about a renewed awareness and interest in geothermal energy for both electric and nonelectric uses. 
This very large energy resource, available in one form or another in every country on earth, could play an increasingly important role in the overall energy supply. Some countries fortunate enough to be in the major geothermal belts of the world may be able to provide a significant portion of their energy requirements from geothermal resources. However, even countries in areas of normal temperature gradients may find that certain geologic, climatic, and economic circumstances may combine to create a favorable economic setting for utilizing hot subsurface water.

The purpose of this report is to review the prospects for geothermal energy over the next fifty years and to summarize its practical uses and future potential. The source material for the report includes information published in the open literature; responses to a questionnaire sent to member countries of the World Energy Conference and many nonmember nations; and a generalized analytic estimate of national resources, using uniform criteria. A comprehensive assessment of worldwide geothermal potential was prepared. The potential includes such factors as total stored energy above a specified temperature and depth (the resource base), actual utilization (to the extent reported), ongoing development, and prospects for the future.

Our knowledge about geothermal energy is still very limited. The information used in the compilation of this report was incomplete in many instances; an effort has therefore been made to indicate the sources as being either the survey questionnaire, the literature, or analytic derivation, including the underlying assumptions. It is hoped that this initial assessment will be of use to the nations of the world in their specific investigations of how geothermal energy can play a role in meeting world energy requirements. 
Section 2

GEOTHERMAL RESOURCES

Temperatures of the earth's crust increase with depth at varying rates, depending on location. The normal temperature gradient is about $25^{\circ} \mathrm{C} / \mathrm{km}$ depth. Thus, in a region where the ambient surface temperature (mean annual temperature) is $15^{\circ} \mathrm{C}$, it is expected that a random hole drilled to a depth of 1 kilometer will encounter a temperature of $40^{\circ} \mathrm{C}$ (the ambient temperature plus the temperature increase due to the normal temperature gradient in the region). However, in some regions of the world the temperature gradient is much greater than normal, increasing in places to a gradient as high as $1^{\circ} \mathrm{C} / \mathrm{m}$. In those areas associated with recent volcanism, relatively high temperatures may be encountered at shallow depth.

\section{GEOTHERMAL ENERGY RESOURCE TYPES}

Geothermal resources are divided into three basic types: 1iquid-dominated and vapor-dominated hydrothermal systems; hot dry rock systems; and geopressured systems. These types are characterized by their thermodynamic and hydrologic properties, as discussed below.

\section{Liquid-Dominated Systems}

Liquid-dominated geothermal resources are those controlled by the presence of circulating liquids (water or brine) that can transport the thermal energy of the rock from deep regions to near-surface regions by natural circulation. The temperature of known liquid-dominated geothermal systems varies from ambient or slightly above to as high as $360^{\circ} \mathrm{C}$. Most investigators agree that liquiddominated resource types are far more abundant than the vapor-dominated ones. Certainly far more liquid-dominated systems have been discovered than vapordominated systems.

Usually the temperature in the best liquid-dominated geothermal regions increases rapidly with depth until the temperature reaches the boiling point of water. Further increases in temperature with depth will be slight until a depth is reached where liquid domination ceases. Temperatures seldom exceed the boiling point of water at prevailing hydrostatic pressures. 
Vapor-Dominated Systems

Vapor-dominated systems, sometimes referred to as dry steam fields, are relatively

rare. However, the most important and successful geothermal power developments in the world today are associated wih the development of vapor-dominated systems (Lardere110, Italy; The Geysers, California; and Matsukawa, Japan). In such systems the continuous phase within the pore space in the near-surface region is that of steam, while in the deeper regions water is presumed to be present. Temperatures are typically in the range of $220-150^{\circ} \mathrm{C}$. Production of steam from this type of reservoir is relatively simple, and quite of ten a slight superheating of the steam occurs during production.

Hot Dry Rock Systems

Since temperatures increase with depth independent of hydrothermal convection, it is reasonable to assume that much more heat is stored in the rock matrix than in the circulating water. Since porosity generally decreases with depth, it may be further assumed that vast volumes of hot dry rock exist at greater depths within the earth's crust. Research efforts are under way to develop methods of introducing cold surface waters into such hot dry rock systems with natural or artificially induced fractures and extracting heated water through a pattern of holes drilled in the vicinity of the injection holes. Calculations suggest that the heat reserve in known geothermal systems is much larger than the heat contained in the fluids only. It is conceivable that many of the hydrothermal systems known today could become depleted of geofluids long before the heat reserve itself has been exhausted. Thus, it is possible that today's liquid-dominated geothermal systems may be further exploited as hot dry rock systems at some time in the future.

\section{Geopressured Systems}

Geopressured reservoirs are generally located in deep sedimentary strata in geologic regions where sediment compaction has taken place over geologic periods of time and where an effective shale cap has formed. Under conditions of shale compression, in which water is squeezed out of the shale matrix into adjacent sand bodies, an internal pressure greater than the ordinary hydrostatic pressure at that depth is imparted to the water. In extreme cases of geopressure, water pressures approach those of the overall weight of the overlying rocks (close to lithostatic pressure). This overpressured water system, known as a geopressured geothermal resource, is of ten characterized by higher-than-normal temperature gradients because of the increased specific heat capacity of the overpressured 
rock-water system. Temperatures as high as $237^{\circ} \mathrm{C}$ have been encountered in some geopressured zones in the Gulf Coast of the United States, with wellhead pressures in excess of $7.6 \times 10^{7} \mathrm{~Pa}(11,000 \mathrm{psi})$. In addition, geopressured fluids typically contain anomalously high concentrations of dissolved methane gas. Practically all large synclinal basins of the world contain some geopressured zones. In the United States alone, geopressured geothermal resources cover an area of more than $200,000 \mathrm{~km}^{2}$ in the states of Texas and Louisiana.

\section{GEOGRAPHIC DISTRIBUTION OF GEOTHERMAL RESOURCES}

Geothermal energy resources are concentrated to a large extent along certain we11defined belts, shown in Figure 1. These belts of higher geothermal potential are associated with earthquake activity and recent volcanism. These belts of high volcanic activity, seismicity, and hot spring activity are associated with geologic plate boundaries and cover approximately $10 \%$ of the earth's surface. The most outstanding geothermal belt of the world is the Circum-Pacific Belt (the socalled Belt of Fire). One branch of the belt extends through Central America to the western portion of South America and then to Antarctica. Another branch of the belt runs through the East Pacific region through New Zealand, New Guinea, and Indonesia and then branches out north, running through the Philippines, Japan, and Eastern Siberia; it then turns eastward through the Aleutians back to northern Canada. Another outstanding geothermal belt runs through East Africa, Ethiopia, Kenya, Tanzania, and gradually weakens southward. The western branch of the Circum-Pacific Belt extends through northern India, Iran, Turkey, and Greece. A continuation of that belt runs through Italy and probably through North Africa. The Mid-Atlantic Ridge Belt usually runs underwater. However, where islands have formed following volcanic eruptions associated with the separation of the major earth plates, considerable geothermal activity is to be found, as in Iceland or in the Azores chain. Geopressured resources are also abundant in many major sedimentary regions of the world, including the Gulf Coast of the United States, the North Sea, western India, and the Persian Gulf. 


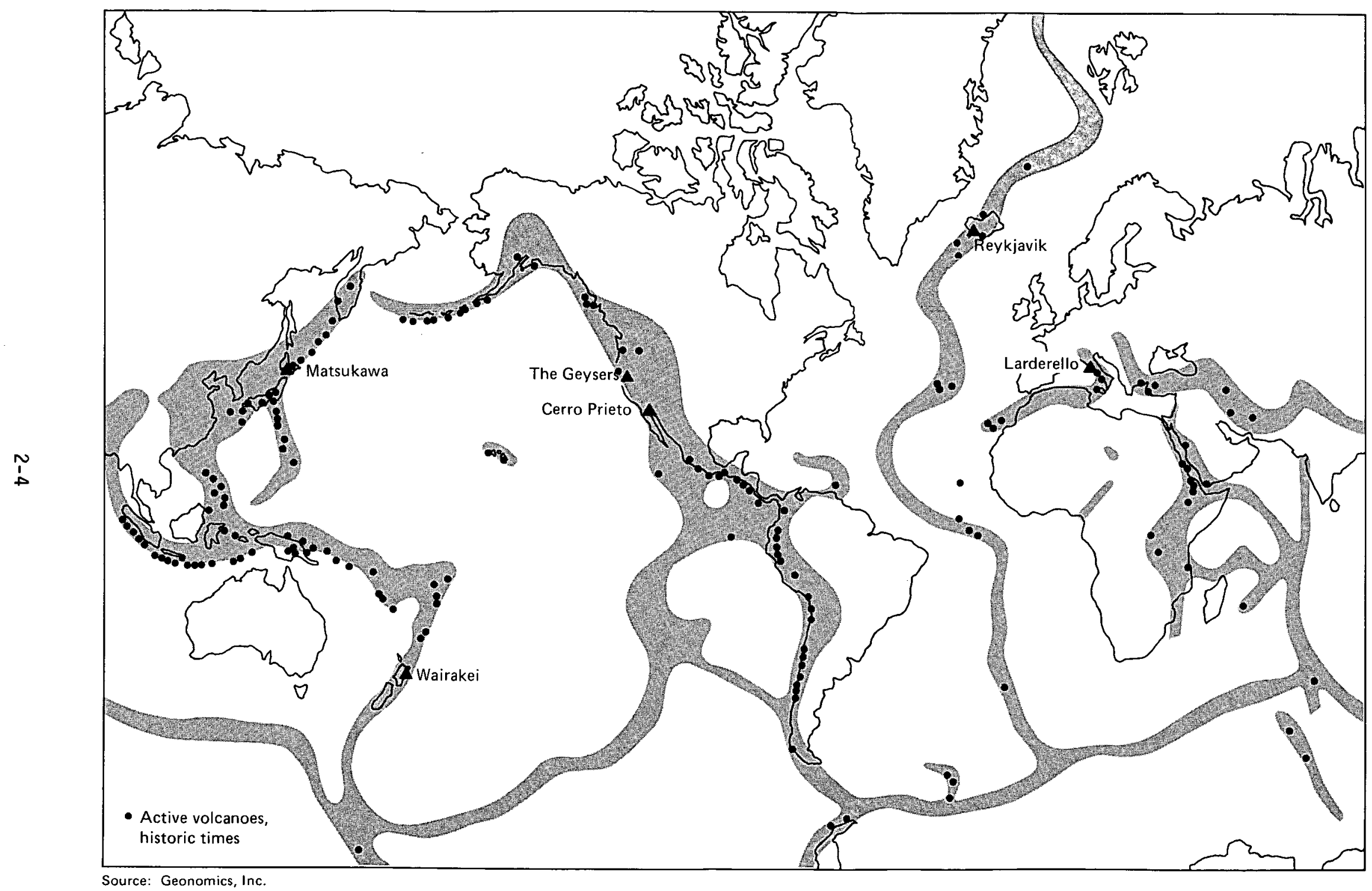

Figure 1 Geothermal regions of the world 


\section{Analytic Estimates}

Active geothermal exploration is proceeding in practically all countries that are crossed by the major geothermal belts. In many. countries where fossil fuel resources are not known to exist or are in short supply, exploration of hot water resources for direct heat purposes is currently under way. Estimates of the geothermal resource base for member nations of the World Energy Conference and many nonmember nations were derived by a simple analysis involving a number of assumptions with respect to heat content and volumes of thermal resources. The results are given in Table 3 .

Notation $E$ in Table 3 represents the power of 10 . For example, 2.4 E6 is equivalent to $2.4 \times 10^{6}$. It is noted that the resource base in the $<100^{\circ} \mathrm{C}$ class is by far the largest quantity. Although this class is too low in temperature for electric power generation, it may be useful for space heating and other direct heat uses, provided the economics of drilling and producing this portion of the resource is favorable in some particular regions of the world. The resource in the $100-150^{\circ} \mathrm{C}$ class is not likely to be economical for electric power generation in many nations. However, this part of the resource can be used for direct heat uses. The total worldwide resource base (in the continental masses to $3 \mathrm{~km}$ depth) for these two temperature classes is $3.8 \times 10^{25}$ and $3.8 \times 10^{24} \mathrm{~J}$, respectively. The resources in the $150-250^{\circ} \mathrm{C}$ and $>250^{\circ} \mathrm{C}$ classes are currently competitive with fossil fuels for electric power generation; the higher the temperature, the better are their thermodynamic and economic efficiencies. The resource bases in these two $c l a s s e s$ are $9.6 \times 10^{23}$ and $5.0 \times 10^{22} \mathrm{~J}$, respectively. Assuming a commonly accepted average net electric power conversion efficiency of $3 \%$ of the gross heat, the total electric energy stored under these two classes is estimated as $9.6 \times 10^{3}$ GW cen (gigawatt-centuries).

Assumptions. The following assumptions were used in calculating the resource base:

1. Al1 "normal" areas of the world have a vertical temperature gradient of $25^{\circ} \mathrm{C} / \mathrm{km}$ depth. 


\section{Table 3}

CALCULATED WORLDWIDE GEOTHERMAL RESOURCE BASE (joules)

\begin{tabular}{|c|c|c|c|c|c|c|c|}
\hline \multirow[b]{2}{*}{ Country } & \multirow[b]{2}{*}{ Area $\left(\mathrm{km}^{2}\right)$} & \multicolumn{6}{|c|}{ Resource Base in Temperature Classes $\left({ }^{\circ} \mathrm{C}\right)$} \\
\hline & & $x$ & $\begin{array}{c}<100 \\
\text { (Class 1) }\end{array}$ & $\begin{array}{l}100-150 \\
\text { (Class 2) }\end{array}$ & $\begin{array}{l}150-250 \\
\text { (Class 3) }\end{array}$ & $\begin{array}{c}>250 \\
\text { (Class 4) }\end{array}$ & Total \\
\hline Algeria* & $2.4 \mathrm{E} 6$ & 0.007 & 6.7 E23 & 3.6 E21 & 9.6 E20 & $5.9 \mathrm{E} 19$ & 6.7 E23 \\
\hline Angola* & $1.3 \mathrm{E} 6$ & 0 & 3.5 E23 & 0 & 0 & 0 & 3.5 E23 \\
\hline Argentina* & $2.8 \mathrm{E} 6$ & 0.03 & 8.0 E23 & 1.8 E22 & 5.0 E21 & 2.9 E20 & 8.4 E23 \\
\hline Australia & 7.7 E6 & 0 & 2.2 E24 & 0 & 0 & 0 & $2.2 \mathrm{E} 24$ \\
\hline Austria & $8.4 \mathrm{E} 4$ & 0 & 2.4 E22 & 0 & 0 & 0 & 2.4 E22 \\
\hline Bangladesh & $1.4 \mathrm{E} 5$ & 0 & $4.0 \mathrm{E} 22$ & 0 & 0 & 0 & $4.0 \mathrm{E} 22$ \\
\hline Barbados* & $4.3 \mathrm{E} 2$ & 1.00 & 9.2 E 19 & $9.6 \mathrm{E} 19$ & $2.5 \mathrm{E} 19$ & 1.5 E18 & $2.1 \mathrm{E} 20$ \\
\hline Belgium & $3.1 \mathrm{E} 4$ & 0 & 8.8 E21 & 0 & 0 & 0 & $8.8 \mathrm{E} 21$ \\
\hline Bolivia* & $1.1 \mathrm{E} 6$ & 0.30 & 2.9 E23 & 7.1 E22 & $1.9 \mathrm{E} 22$ & $1.2 \mathrm{E} 21$ & $3.8 \mathrm{E} 23$ \\
\hline Brazil* & 8.5 E6 & 0.05 & 2.4 E24 & 9.2 E22 & $2.5 \mathrm{E} 22$ & 1.5 E21 & $2.5 \mathrm{E} 24$ \\
\hline Bulgaria & $1.1 \mathrm{E} 5$ & 0 & 3.1 E22 & $2.4 \mathrm{E} 20$ & $6.3 \mathrm{E} 19$ & $4.0 \mathrm{E} 18$ & 3.2 E22 \\
\hline Burundi* & $2.8 \mathrm{E} 4$ & 1.00 & $5.9 \mathrm{E} 21$ & $6.3 \mathrm{E} 21$ & $1.6 \mathrm{E} 21$ & $1.0 \mathrm{E} 20$ & $1.4 \mathrm{E} 22$ \\
\hline Cameroon* & $4.8 \mathrm{E} 5$ & 0.10 & 1.3 E23 & 1.0 E22 & $2.8 \mathrm{E} 21$ & 1.7 E20 & $1.5 \mathrm{E} 23$ \\
\hline Canada* & $1.0 \mathrm{E} 6$ & 0.20 & 2.7 E24 & $4.6 \mathrm{E} 23$ & $1.2 \mathrm{E} 23$ & 7.1 E21 & $3.3 \mathrm{E} 24$ \\
\hline Chad $^{*}$ & $1.3 \mathrm{E} 6$ & 0.10 & $3.5 \mathrm{E} 23$ & $2.8 \mathrm{E} 22$ & $7.5 \mathrm{E} 21$ & $4.6 \mathrm{E} 20$ & $3.8 \mathrm{E} 23$ \\
\hline Chile* & $7.6 \mathrm{E} 5$ & 1.00 & $1.6 \mathrm{E} 23$ & $1.7 \mathrm{E} 23$ & $4.6 \mathrm{E} 22$ & 2.7 E21 & $3.8 \mathrm{E} 23$ \\
\hline China* & $9.6 \mathrm{E} 6$ & 0.25 & 2.6 E24 & $5.4 \mathrm{E} 23$ & $1.4 \mathrm{E} 23$ & 8.4 E21 & 3.2 E24 \\
\hline
\end{tabular}

${ }^{*}$ Country is in conjectured geothermal belt, not yet proven by exploration. 
Table 3 (continued)

\begin{tabular}{|c|c|c|c|c|c|c|c|}
\hline \multirow{2}{*}{ Country } & \multirow{2}{*}{ Area $\left(\mathrm{km}^{2}\right)$} & \multicolumn{6}{|c|}{ Resource Base in Temperature Classes $\left({ }^{\circ} \mathrm{C}\right)$} \\
\hline & & $x$ & $\begin{array}{l}<100 \\
\text { (Class 1) }\end{array}$ & $\begin{array}{l}100-150 \\
\text { (Class 2) }\end{array}$ & $\begin{array}{l}150-250 \\
\text { (Class 3) }\end{array}$ & $\begin{array}{l}>250 \\
\text { (Class 4) }\end{array}$ & Total \\
\hline Colombia* & $1.1 \mathrm{E} 6$ & 0.30 & 3.0 E23 & 7.5 E22 & 2.0 E22 & 1.2 E21 & 3.9 E23 \\
\hline Costa Rica & $5.1 \mathrm{E} 4$ & 1.00 & $1.1 \mathrm{E} 22$ & $1.1 \mathrm{E} 22$ & 3.0 E21 & $1.8 \mathrm{E} 20$ & $2.5 \mathrm{E} 22$ \\
\hline Cuba & $1.1 \mathrm{E} 5$ & 0 & 3.2 E22 & 0 & 0 & 0 & $3.2 \mathrm{E} 22$ \\
\hline Cyprus & $9.3 \mathrm{E} 3$ & 0 & $2.6 \mathrm{E} 21$ & 0 & 0 & 0 & 2.6 E21 \\
\hline Czechoslovakia` & $1.3 \mathrm{E} 5$ & 0.10 & 3.5 E22 & 2.8 E21 & 7.5 E20 & 4.6 E 19 & $3.8 \mathrm{E} 22$ \\
\hline Dahomey & $1.2 \mathrm{E} 5$ & 0 & 3.3 E22 & 0 & 0 & 0 & $3.3 E 22$ \\
\hline Denmark & $4.3 \mathrm{E} 4$ & 0 & $1.2 \mathrm{E} 22$ & 0 & 0 & 0 & $1.2 \mathrm{E} 22$ \\
\hline Dominican Rep.* & $4.8 E 4$ & 0.25 & $1.3 \mathrm{E} 22$ & 2.7 E21 & $7.1 \mathrm{E} 20$ & $4.2 \mathrm{E} 19$ & $1.6 \mathrm{E} 22$ \\
\hline Ecuador & $4.6 \mathrm{E} 5$ & 1.00 & $1.0 \mathrm{E} 23$ & 1.0 E23 & 2.6 E22 & 1.6 E21 & $2.3 \mathrm{E} 23$ \\
\hline Egypt & $9.5 \mathrm{E} 5$ & 0 & $2.7 \mathrm{E} 23$ & 0 & 0 & 0 & 2.7 E23 \\
\hline El Salvador & $2.1 \mathrm{E} 4$ & 1.00 & 4.6 E21 & 4.6 E21 & $1.2 \mathrm{E} 21$ & $7.5 \mathrm{E} 19$ & $1.0 E 22$ \\
\hline England & $1.3 \mathrm{E} 5$ & 0 & 3.7 E22 & 0 & 0 & 0 & 3.7 E22 \\
\hline Ethiopia & $1.2 \mathrm{E} 6$ & 0.60 & $3.0 \mathrm{E} 23$ & 1.6 E23 & 4.2 E22 & 2.6 E21 & $5.0 \mathrm{E} 23$ \\
\hline Fiji** & $1.8 \mathrm{E} 4$ & 0.20 & 5.0 E21 & 8.0 E20 & $2.1 \mathrm{E} 20$ & 1.3 E 19 & 5.9 E21 \\
\hline Finland & $3.6 \mathrm{E} 5$ & 0 & $1.0 \mathrm{E} 23$ & 0 & 0 & 0 & $1.0 \mathrm{E} 23$ \\
\hline France & $5.5 \mathrm{E} 5$ & 0 & $1.5 \mathrm{E} 23$ & 0 & 0 & 0 & $1.5 \mathrm{E} 23$ \\
\hline Germany, East & $1.1 \mathrm{E} 5$ & 0 & 3.1 E22 & 0 & 0 & 0 & $3.1 \mathrm{E} 22$ \\
\hline Germany, West & $2.5 \mathrm{E} 5$ & 0 & 7.1 E22 & 0 & 0 & 0 & 6.7 E22 \\
\hline
\end{tabular}

*Country is in conjectured geothermal belt, not yet proven by exploration. 
Table 3 (continued)

\begin{tabular}{|c|c|c|c|c|c|c|c|}
\hline \multirow[b]{2}{*}{ Country } & \multirow[b]{2}{*}{ Area $\left(\mathrm{km}^{2}\right)$} & \multicolumn{6}{|c|}{ Resource Base in Temperature Classes $\left({ }^{\circ} \mathrm{C}\right)$} \\
\hline & & $x$ & $\begin{array}{l}<100 \\
\text { (Class 1) }\end{array}$ & $\begin{array}{l}100-150 \\
\text { (Class 2) }\end{array}$ & $\begin{array}{l}150-250 \\
\text { (Class } 3 \text { ) }\end{array}$ & $\begin{array}{c}>250 \\
\text { (Class 4) }\end{array}$ & Total \\
\hline Ghana & $2.4 \mathrm{E5}$ & 0 & 6.7 E22 & 0 & 0 & 0 & 6.7 E22 \\
\hline Greece & $1.3 \mathrm{E} 5$ & 0.30 & $3.5 \mathrm{E} 22$ & 8.8 E21 & $2.3 \mathrm{E} 21$ & 1.4 E20 & $4.6 \mathrm{E} 22$ \\
\hline Greenland & 2.2 E6 & 0 & $6.3 \mathrm{E} 23$ & 0 & 0 & 0 & 6.3 E23 \\
\hline Guadeloupe & $1.8 \mathrm{E} 3$ & 1.00 & 3.8 E20 & 3.9 E20 & 1.0 E20 & $6.3 \mathrm{E} 18$ & $8.8 \mathrm{E} 20$ \\
\hline Guatemala & $1.1 \mathrm{E} 5$ & 1.00 & $1.4 \mathrm{E} 22$ & 2.4 E22 & $6.3 \mathrm{E} 21$ & $3.9 \mathrm{E} 20$ & $4.6 \mathrm{E} 22$ \\
\hline Haiti* & $2.8 \mathrm{E} 4$ & 0.025 & $8.0 \mathrm{E} 21$ & $1.5 \mathrm{E} 20$ & $4.0 \mathrm{E} 19$ & $2.5 \mathrm{E} 18$ & $8.0 \mathrm{E} 21$ \\
\hline Honduras* & $1.1 \mathrm{E} 5$ & 0.50 & $2.5 \mathrm{E} 22$ & $1.2 \mathrm{E} 22$ & 3.3 E21 & $2.0 \mathrm{E} 20$ & $4.2 \mathrm{E} 22$ \\
\hline Hungary & $9.3 \mathrm{E} 4$ & 0 & $2.6 \mathrm{E} 22$ & 0 & 0 & 0 & $2.6 \mathrm{E} 22$ \\
\hline Iceland & $1.0 \mathrm{E} 5$ & 1.00 & $2.2 \mathrm{E} 22$ & $2.3 E 22$ & 5.9 E21 & 3.7 E20 & 5.0 E22 \\
\hline India* & $3.3 \mathrm{E} 6$ & 0.02 & 9.2 E23 & $1.4 \mathrm{E} 22$ & 3.8 E21 & $2.3 \mathrm{E} 20$ & $9.2 \mathrm{E} 23$ \\
\hline Indonesia & $1.9 \mathrm{E} 6$ & 1.00 & 4.1 E23 & 4.2 E22 & 1.1 E23 & 6.7 E21 & 9.6 E23 \\
\hline $\operatorname{Iran} *$ & $1.7 \mathrm{E} 6$ & 0.20 & 4.6 E23 & 7.1 E22 & 1.9 E22 & $1.2 \mathrm{E} 21$ & $5.4 \mathrm{E} 23$ \\
\hline Iraq & $4.3 \mathrm{E} 5$ & 0 & $1.2 \mathrm{E} 23$ & 0 & 0 & 0 & $1.2 \mathrm{E} 23$ \\
\hline Ireland & $7.0 \mathrm{E} 4$ & 0 & 2.0 E22 & 0 & 0 & 0 & $2.0 \mathrm{E} 22$ \\
\hline |srael* & $2.1 \mathrm{E} 4$ & 0.025 & 5.9 E21 & 1.2 E20 & $3.1 \mathrm{E} 19$ & $1.9 \mathrm{E} 18$ & $5.9 \mathrm{E} 21$ \\
\hline Italy & 3.0 E5 & 0.50 & 7.5 E22 & 3.3E22 & 8.8 E21 & $5.4 \mathrm{E} 20$ & $1.2 \mathrm{E} 23$ \\
\hline Ivory Coast & $3.2 \mathrm{E} 5$ & 0 & $9.2 \mathrm{E} 22$ & 0 & 0 & 0 & $9.2 \mathrm{E} 22$ \\
\hline Jamaica & $1.1 \mathrm{E} 4$ & 0 & 3.2 E21 & 0 & 0 & 0 & $3.2 \mathrm{E} 21$ \\
\hline
\end{tabular}

* Country is in conjectured geothermal belt, not yet proven by exploration. 
Table 3 (continued)

\begin{tabular}{|c|c|c|c|c|c|c|c|}
\hline \multirow[b]{2}{*}{ Country } & \multirow[b]{2}{*}{ Area $\left(\mathrm{km}^{2}\right)$} & \multicolumn{6}{|c|}{ Resource Base in Temperature Classes $\left({ }^{\circ} \mathrm{C}\right)$} \\
\hline & & $x$ & $\begin{array}{c}<100 \\
\text { (Class 1) }\end{array}$ & $\begin{array}{l}100-150 \\
\text { (Class 2) }\end{array}$ & $\begin{array}{l}150-250 \\
\text { (Class 3) }\end{array}$ & $\begin{array}{c}>250 \\
\text { (Class 4) }\end{array}$ & Total \\
\hline Japan & $3.7 \mathrm{E} 5$ & 1.00 & 8.0 E22 & 8.0 E22 & $2.1 \mathrm{E} 22$ & 1.3 E21 & $1.8 \mathrm{E} 23$ \\
\hline Jordan* & $9.8 \mathrm{E} 4$ & 0.025 & 2.8 E22 & 5.4 E20 & 1.5 E20 & 8.8 E 18 & $2.8 \mathrm{E} 22$ \\
\hline Kenya & $5.8 \mathrm{E} 5$ & 0.60 & $1.4 \mathrm{E} 23$ & $7.5 \mathrm{E} 22$ & $2.0 \mathrm{E} 22$ & 1.3 E21 & 2.4 E23 \\
\hline Korea* (N \& S) & $2.2 \mathrm{E5}$ & 0.50 & $5.4 \mathrm{E} 22$ & $2.4 \mathrm{E} 22$ & 6.3 E21 & 3.9 E20 & 8.8 E22 \\
\hline Kuwait & $2.0 \mathrm{E} 4$ & 0 & 5.9 E21 & 0 & 0 & 0 & 5.9 E21 \\
\hline Liberia & $1.1 \mathrm{E} 5$ & 0 & 3.1 E22 & 0 & 0 & 0 & $3.1 \mathrm{E} 22$ \\
\hline Libya & $1.8 \mathrm{E} 6$ & 0 & 5.0 E21 & 0 & 0 & 0 & $5.0 \mathrm{E} 21$ \\
\hline Luxembourg & $2.6 \mathrm{E} 3$ & 0 & 7.5 E20 & 0 & 0 & 0 & 7.5 E20 \\
\hline Malawi* & $9.5 \mathrm{E} 4$ & 0.01 & 2.7 E22 & 2.1 E20 & $5.4 \mathrm{E} 19$ & 3.4 E 18 & 2.7 E22 \\
\hline Malagasy Rep.* & $5.9 \mathrm{E} 5$ & 0.005 & 1.6 E23 & 6.3 E20 & 1.7 E20 & $1.0 \mathrm{E} 19$ & $1.6 \mathrm{E} 23$ \\
\hline Malaysia & $3.3 \mathrm{E} 5$ & 0.02 & 9.2 E22 & 1.4 E21 & $3.8 \mathrm{E} 20$ & 2.3 E19 & 9.2 E22 \\
\hline Mali & $1.2 \mathrm{E} 6$ & 0 & 3.4 E23 & 0 & 0 & 0 & 3.4 E23 \\
\hline Martinique & $1.1 \mathrm{E} 3$ & 1.00 & 2.4 E20 & 2.4 E20 & $6.3 \mathrm{E} 19$ & 3.9 E18 & 5.4 E20 \\
\hline Mexico & $2.0 \mathrm{E} 6$ & 0.60 & $4.6 \mathrm{E} 23$ & 2.6 E23 & 6.7 E22 & 4.2 E21 & 8.0 E23 \\
\hline Morocco & $4.4 \mathrm{E} 5$ & 0.04 & 1.3 E23 & 3.9 E21 & $1.0 \mathrm{E} 21$ & 4.2 E21 & 8.0 E23 \\
\hline Nepal & $1.4 \mathrm{E} 5$ & 0.10 & 3.9 E22 & 3.1 E21 & 8.4 E20 & 5.0 E 19 & 4.2 E22 \\
\hline Netherlands & $3.6 \mathrm{E} 4$ & 0 & $1.0 \mathrm{E} 22$ & 0 & 0 & 0 & 1.0 E22 \\
\hline New Guinea & $2.4 \mathrm{E} 5$ & 0.60 & $5.9 \mathrm{E} 22$ & 3.1 E22 & 8.4 E21 & 5.0 E20 & 9.6 E22 \\
\hline
\end{tabular}

${ }^{*}$ Country is in conjectured geothermal belt, not yet proven by exploration. 
Table 3 (continued)

\begin{tabular}{|c|c|c|c|c|c|c|c|}
\hline \multirow[b]{2}{*}{ Country } & \multirow[b]{2}{*}{ Area $\left(\mathrm{km}^{2}\right)$} & \multicolumn{6}{|c|}{ Resource Base in Temperature Classes $\left({ }^{\circ} \mathrm{C}\right)$} \\
\hline & & $x$ & $\begin{array}{c}<100 \\
\text { (Class 1) }\end{array}$ & $\begin{array}{l}100-150 \\
\text { (Class 2) }\end{array}$ & $\begin{array}{l}150-250 \\
\text { (Class 3) }\end{array}$ & $\begin{array}{l}>250 \\
\text { (Class 4) }\end{array}$ & Total \\
\hline New Hebrides & $1.5 \mathrm{E} 4$ & 1.00 & 3.2 E21 & 3.3 E21 & 8.8 E20 & 5.4 E19 & $7.5 \mathrm{E} 21$ \\
\hline New Zealand & $2.7 \mathrm{E} 5$ & 0.50 & 6.7 E22 & 2.9 E22 & $8.0 \mathrm{E} 21$ & 4.6 E20 & $1.0 \mathrm{E} 23$ \\
\hline Nicaragua & $1.5 \mathrm{E} 5$ & 1.00 & 3.2 E22 & 3.3 E22 & $8.8 \mathrm{E} 21$ & 5.4 E20 & $7.5 \mathrm{E} 22$ \\
\hline Nigeria & $9.2 \mathrm{E} 5$ & 0 & 2.6 E23 & 0 & 0 & 0 & $2.6 \mathrm{E} 23$ \\
\hline Norway & $3.2 \mathrm{E} 5$ & 0 & 9.2 E22 & 0 & 0 & 0 & $9.2 \mathrm{E} 22$ \\
\hline Pakistan & $8.4 \mathrm{E} 6$ & 0.01 & 2.3 E24 & 1.8 E22 & $5.0 \mathrm{E} 21$ & 3.0 E20 & $2.3 \mathrm{E} 24$ \\
\hline Panama* & $7.6 \mathrm{E} 4$ & 1.00 & $1.6 \mathrm{E} 22$ & 1.7 E22 & $4.6 \mathrm{E} 21$ & 2.7 E20 & $3.8 \mathrm{E} 22$ \\
\hline Paraguay* & $4.1 \mathrm{E} 5$ & 0.10 & 1.1 E23 & 8.8 E21 & 2.4 E21 & 1.5 E20 & $1.3 \mathrm{E} 23$ \\
\hline Peru* & $1.3 \mathrm{E} 6$ & 1.00 & 2.8 E 23 & 2.8 E23 & 7.5 E22 & 4.6 E21 & $6.3 \mathrm{E} 23$ \\
\hline Philippines & $3.0 \mathrm{E} 5$ & 1.00 & 6.3 E22 & 6.7 E22 & $1.8 \mathrm{E} 22$ & $1.1 \mathrm{E} 21$ & $1.5 \mathrm{E} 23$ \\
\hline Poland & $3.1 \mathrm{E} 5$ & 0 & 8.8 E22 & 0 & 0 & 0 & $8.8 \mathrm{E} 22$ \\
\hline Portugal & $9.2 \mathrm{E} 4$ & 0.05 & 2.6 E22 & 1.0 E21 & 2.7 E20 & $1.6 \mathrm{E} 19$ & $2.7 \mathrm{E} 22$ \\
\hline Rumania & $2.4 \mathrm{E} 5$ & 0.01 & 6.7 E22 & 5.0 E20 & 1.4 E20 & 8.4 E 18 & $6.7 \mathrm{E} 22$ \\
\hline Saudi Arabia* & $2.3 \mathrm{E} 6$ & 0.02 & 6.3 E23 & 1.0 E22 & 2.6 E21 & 1.6 E20 & $6.3 \mathrm{E} 23$ \\
\hline Senegal & $2.0 \mathrm{E} 5$ & 0 & 5.4 E22 & 0 & 0 & 0 & $5.4 \mathrm{E} 22$ \\
\hline Sierra Leone & $7.2 \mathrm{E} 4$ & 0 & 2.1 E22 & 0 & 0 & 0 & $2.1 \mathrm{E} 22$ \\
\hline South Africa & $1.2 \mathrm{E} 6$ & 0 & 3.4 E23 & 0 & 0 & 0 & 3.4 E23 \\
\hline Spain & $5.1 \mathrm{E} 5$ & 0.05 & 1.4 E23 & 5.4 E21 & 1.5 E21 & 9.2 E 19 & $1.5 \mathrm{E} 23$ \\
\hline
\end{tabular}

${ }^{*}$ Country is in conjectured geothermal belt, not yet proven by exploration. 
Table 3 (continued)

$\begin{array}{lcc} & & \\ \text { Country } & \text { Area }\left(\mathrm{km}^{2}\right) & X \\ & & \\ \text { Sri Lanka } & 6.6 \mathrm{E} 4 & 0 \\ \text { Sudan } & 2.5 \mathrm{E} 6 & 0 \\ \text { Sweden } & 4.5 \mathrm{E5} & 0 \\ \text { Switzerland } & 4.1 \mathrm{E} 4 & 0 \\ \text { Taiwan } & 3.6 \mathrm{E} 4 & 1.00 \\ \text { Tanzania } & 9.4 \mathrm{E5} & 0.03 \\ \text { Thailand } & 5.1 \mathrm{E5} & 0 \\ \text { Trinidad \& Tobago } & 5.1 \mathrm{ES} & 1.00 \\ \text { Tunisia } & 1.6 \mathrm{E5} & 0.01 \\ \text { Turkey } & 7.8 \mathrm{E5} & 0.50 \\ \text { United States } & 9.4 \mathrm{E} 6 & 0.25 \\ \text { Uruguay } & 1.9 \mathrm{E5} & 0.01 \\ \text { USSR } & 2.2 \mathrm{E} 7 & 0.05 \\ \text { Venezuela } & 9.1 \mathrm{E5} & 0.20 \\ \text { Vietnam (N \& S) } & 3.3 \mathrm{E5} & 0.50 \\ \text { Yugoslavia } & 2.6 \mathrm{E5} & 0 \\ \text { Zaire } & 2.3 \mathrm{E} 6 & 0.01 \\ \text { Zambia } & 7.5 \mathrm{E5} & 0.10\end{array}$

Resource Base in Temperature Classes $\left({ }^{\circ} \mathrm{C}\right)$

$$
\begin{array}{ccccc}
<100 & 100-150 & 150-250 & >250 & \\
\text { (Class 1) } & \text { (Class 2) } & \text { (Class 3) } & \text { (Class 4) } & \text { Total }
\end{array}
$$

$\begin{array}{lcccc}1.8 \mathrm{E} 22 & 0 & 0 & 0 & 1.8 \mathrm{E} 22 \\ 7.1 \mathrm{E} 23 & 0 & 0 & 0 & 7.1 \mathrm{E} 23 \\ 1.3 \mathrm{E} 23 & 0 & 0 & 0 & 1.3 \mathrm{E} 23 \\ 1.2 \mathrm{E} 22 & 0 & 0 & 0 & 1.2 \mathrm{E} 22 \\ 7.5 \mathrm{E} 21 & 8.0 \mathrm{E} 21 & 2.1 \mathrm{E} 21 & 1.3 \mathrm{E} 20 & 1.8 \mathrm{E} 22 \\ 2.6 \mathrm{E} 23 & 6.3 \mathrm{E} 21 & 1.6 \mathrm{E} 21 & 1.0 \mathrm{E} 20 & 2.6 \mathrm{E} 23 \\ 1.5 \mathrm{E} 23 & 0 & 0 & 0 & 1.5 \mathrm{E} 23 \\ 1.1 \mathrm{E} 21 & 1.1 \mathrm{E} 21 & 3.0 \mathrm{E} 20 & 1.8 \mathrm{E} 19 & 2.6 \mathrm{E} 21 \\ 4.6 \mathrm{E} 22 & 3.6 \mathrm{E} 20 & 9.6 \mathrm{E} 19 & 5.9 \mathrm{E} 18 & 4.6 \mathrm{E} 22 \\ 1.9 \mathrm{E} 23 & 8.4 \mathrm{E} 22 & 2.3 \mathrm{E} 22 & 1.4 \mathrm{E} 21 & 3.1 \mathrm{E} 23 \\ 4.1 \mathrm{E} 24 & 5.0 \mathrm{E} 23 & 1.3 \mathrm{E} 23 & 8.4 \mathrm{E} 21 & 4.6 \mathrm{E} 24 \\ 5.0 \mathrm{E} 22 & 4.1 \mathrm{E} 20 & 1.1 \mathrm{E} 20 & 6.7 \mathrm{E} 18 & 5.0 \mathrm{E} 22 \\ 6.3 \mathrm{E} 24 & 2.4 \mathrm{E} 23 & 6.3 \mathrm{E} 22 & 4.0 \mathrm{E} 21 & 6.7 \mathrm{E} 24 \\ 2.5 \mathrm{E} 23 & 0 & 1.0 \mathrm{E} 22 & 6.7 \mathrm{E} 20 & 3.0 \mathrm{E} 23 \\ 8.4 \mathrm{E} 22 & 3.7 \mathrm{E} 22 & 9.6 \mathrm{E} 21 & 5.9 \mathrm{E} 20 & 1.3 \mathrm{E} 23 \\ 7.1 \mathrm{E} 22 & 0 & 0 & 0 & 7.1 \mathrm{E} 22 \\ 6.7 \mathrm{E} 23 & 5.0 \mathrm{E} 21 & 1.3 \mathrm{E} 21 & 8.4 \mathrm{E} 19 & 6.7 \mathrm{E} 23 \\ 2.1 \mathrm{E} 23 & 1.7 \mathrm{E} 22 & 6.7 \mathrm{E} 21 & 2.7 \mathrm{E} 20 & 2.3 \mathrm{E} 23\end{array}$


2. There are certain geothermal belts in the world where the vertical temperature gradient is higher than normal. Either part or all of any country may lie in a geothermal belt. Let $A$ denote the total area of a country, of which a fraction $x$ lies in a geothermal belt. $X$ may range from 0 to 1 .

3. Of the geothermal area $(X A)$ in a country, $90 \%(0.9 \times A)$ is assumed to have a temperature gradient of $40^{\circ} \mathrm{C} / \mathrm{km}$ depth and $10 \%(0.1 \mathrm{XA})$ is assumed to have a temperature gradient of $80^{\circ} \mathrm{C} / \mathrm{km}$.

4. The average ambient atmospheric temperature of all countries is assumed to be $15^{\circ} \mathrm{C}$.

5. For the purpose of this report, the geothermal resource base of a country is defined as the total heat contained in subsurface rocks and fluids to a depth of $3 \mathrm{~km}$ and at temperatures above $15^{\circ} \mathrm{C}$.

6. Four temperature resource classes are considered:

Class 1: $<100^{\circ} \mathrm{C}$

Class 2: $100-150^{\circ} \mathrm{C}$

Class 3: $150-250^{\circ} \mathrm{C}$

Class 4: $>250^{\circ} \mathrm{C}$

7. Although the heat capacity of rock depends on lithology, porosity, and water content, an average volumetric specific heat $\left(C_{v}\right)$ of $2.5 \mathrm{~J} / \mathrm{cm}^{3}{ }^{\circ} \mathrm{C}$ is an acceptable value for most areas.

8. The resource base, $Q$, associated with a particular temperature class is given by

$$
Q=(A)(H)\left(C_{v}\right)(T-15)
$$

where $A$ denotes the area underlain by the resource, $H$ the thickness (depth range) of the resource, $C_{v}$ the volumetric specific heat of the subsurface material, and $T$ the average temperature of the resource. Taking $A$ in $\mathrm{cm}^{2}, H$ in $\mathrm{cm}, \mathrm{C}_{v}=2.5 \mathrm{~J} / \mathrm{cm}^{3}{ }^{\circ} \mathrm{C}$, and $\mathrm{T}$ in ${ }^{\circ} \mathrm{C}$,

$$
Q=(2.5)(A)(H)(T-15) \mathrm{J}
$$


9. In any temperature class, $20 \%$ of the total resource base is stored in the water and steam and the remainder is stored in the rock matrix. The rationale is as follows: Assuming the porosity range of subsurface material to be from 5 to $20 \%$, the amount of water in $1 \mathrm{~cm}^{3}$ of porous rock varies from 0.05 to $0.2 \mathrm{~cm}^{3}$. Assuming an approximate volumetric specific heat capacity of from 0.21 to $0.84 \mathrm{~J} /{ }^{\circ} \mathrm{C}$, compared with $2.5 \mathrm{~J} /{ }^{\circ} \mathrm{C}$ for the $1-\mathrm{cm}^{3}$ rock-fluid system (assumption 7 ), the fraction of the resource base stored in water is from $0.21 / 2.5$ to $0.84 / 2.5$, or from 8.3 to $33.3 \%$, with the average assumed to be $20 \%$. The remaining $80 \%$ of the resource base is assumed to be stored in the rock.

\section{Calculation Procedure.}

1. Data on the surface area of each country were obtained from The Times Atlas of the World (1974) and converted to square centimeters.

2. The value $X$ for each country was determined by estimating areal fractions in Figure 1 by expert, but subjective, judgment.

3. Resource base in normal areas:

Area of normal gradient $=(A-X A) \mathrm{cm}^{2}$

Temperature gradient $=25^{\circ} \mathrm{C} / \mathrm{km}$

Temperature $(T)$ at any depth $(h)$ is given by $T=15+25 h$

(e.g., at $3 \mathrm{~km}, \mathrm{~T}=90^{\circ} \mathrm{C}$ ).

Thus, the entire resource in a normal area belongs to $\mathrm{Class} 1$ (i.e., $<100^{\circ} \mathrm{C}$ ). The average temperature to a $3-\mathrm{km}$ depth in the normal areas equals $(15+90) / 2$, or $52.5^{\circ} \mathrm{C}$. Using $Q^{\circ}$ to denote normal areas and $Q_{1}, Q_{2}, Q_{3}$, and $Q_{4}$ to denote the four resource temperature classes, the resource base of the normal areas can be calculated as follows:

$$
Q_{1}^{\circ}=(2.5)(A-X A)(3)(52.5-15)\left(10^{5}\right) \mathrm{J}
$$

or,

$$
\begin{aligned}
& Q_{1}^{\circ}=\left(2.81 \times 10^{7}\right)(A-X A) J \\
& Q_{2}^{\circ}=0
\end{aligned}
$$




$$
\begin{aligned}
& Q_{3}^{\circ}=0 \\
& Q_{4}^{\circ}=0
\end{aligned}
$$

The total resource base in normal areas $=Q_{1}^{\circ}+Q_{2}^{\circ}+Q_{3}^{\circ}+Q_{4}^{\circ}$. Of this resource base, $20 \%$ is classified as hot water or steam and $80 \%$ is in the dry rock category.

4. Resource base in geothermal areas $(90 \%)$ :

Area under consideration $=0.9 \times \mathrm{A} \mathrm{cm}^{2}$

Temperature gradient $=40^{\circ} \mathrm{C} / \mathrm{km}$

Temperature $(T)$ at any depth $(h)$ is given by $T=15+40 \mathrm{~h}$;

or $h=(T-15) / 40$.

The depth to the bottom of the Class 1 resource is $(100-15) / 40$, or $2.125 \mathrm{~km}$. The average temperature between the surface and this depth is $(15+100) / 2$, or $57.5^{\circ} \mathrm{C}$. Denoting these areas by $Q^{1}$ and using $Q_{1}, Q_{2}, Q_{3}$, and $Q_{4}$ to denote resource classes, and using Eq. 2-2,

$$
Q_{1}^{1}=(2.5)(0.9 X A)(2.125)(57.5-15)\left(10^{5}\right) \mathrm{J}
$$

or,

$$
Q_{1}^{1}=\left(2.03 \times 10^{7}\right)(X A) \mathrm{J}
$$

The depth to bottom of the Class 2 resource is $(150-15) / 40$ or $3.38 \mathrm{~km}$. Therefore, only part of the Class 2 resource falls within the $3-\mathrm{km}$ depth range. The temperature at $3-\mathrm{km}$ depth is $15+40(3)$, or $135^{\circ} \mathrm{C}$. The average temperature of the resource between depths 2.125 and $3 \mathrm{~km}$ is $(100+135) / 2$, or $117.5^{\circ} \mathrm{C}$, and the corresponding thickness $\mathrm{h}=(3-2.125)$, or $0.875 \mathrm{~km}$. Therefore, using Eq. 2-2,

$$
Q_{2}^{1}=(2.5)(0.9 \times A)(0.876)(117.5-15)\left(10^{5}\right) \mathrm{J}
$$

or,

$$
Q_{2}^{\frac{1}{2}}=\left(2.02 \times 10^{7}\right)(X A) \mathrm{J}
$$




$$
\begin{aligned}
& Q \frac{1}{3}=0 \\
& Q_{4}^{1}=0
\end{aligned}
$$

The total resource base in $90 \%$ of the geothermal area in a country $=0 \frac{1}{1}+$ $Q_{2}^{1}+Q_{3}^{\frac{1}{3}}+Q_{4}^{1}$. Of this resource $20 \%$ belongs to the hot water or steam classification and $80 \%$ is in the dry rock classification.

5. Resource base in geothermal areas (10\%):

Area under consideration $=0.1 \times \mathrm{Cm}^{2}$

Temperature gradient $=80^{\circ} \mathrm{C} / \mathrm{km}$

Temperature $(T)$ at any depth $(\mathrm{h})$, in $\mathrm{km}$, is given by $T=15+80 \mathrm{~h}$; or $h=(T-15) / 80$.

The depth to bottom of the class 1 resource is $(100-15) / 80$, or $1.063 \mathrm{~km}$. The average temperature between the surface and this depth is $(15+100) / 2$, or $57.5^{\circ} \mathrm{C}$. Denoting these areas by $Q^{2}$ and using $Q_{1}, Q_{2}, Q_{3}$, and $Q_{4}$ to denote resource classes:

$$
\begin{aligned}
& Q_{1}^{2}=(2.5)(0.1 \times A)(1.063)(57.5-15)\left(10^{5}\right) \mathrm{J} \\
& Q_{1}^{2}=\left(1.13 \times 10^{6}\right)(X A) \mathrm{J}
\end{aligned}
$$

The depth to bottom of the Class 2 resource is $(150-15) / 80$, or $1.688 \mathrm{~km}$. The average temperature between $1.063 \mathrm{~km}$ and this depth is $(100+150) / 2$, or $125^{\circ} \mathrm{C}$, and the corresponding thickness $h=1.688-1.063=0.625 \mathrm{~km}$. Using Eq. 2-2,

$$
Q_{2}^{2}=(2.5)(0.1 \times A)(0.625)(125-15)\left(10^{5}\right) \mathrm{J}
$$

or,

$$
Q_{2}^{2}=\left(1.72 \times 10^{6}\right)(X A) \mathrm{J}
$$

The depth to bottom of the class 3 resource is $(250-15) / 80$, or $2.938 \mathrm{~km}$. The average temperature between $1.688 \mathrm{~km}$ and $2.938 \mathrm{~km}$ is $(150+250) / 2$, or $200^{\circ} \mathrm{C}$, and the corresponding thickness $\mathrm{h}=2.938-1.688$, or $1.250 \mathrm{~km}$. Using Eq. 2-2, 


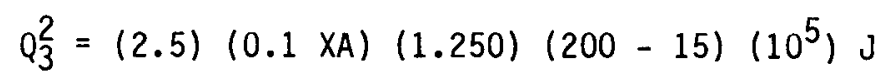

or,

$$
Q_{3}^{2}=\left(5.78 \times 10^{6}\right)(X A) \mathrm{J}
$$

At $3 \mathrm{~km}$, temperature is $15+80(3)$, or $255^{\circ} \mathrm{C}$. Therefore the average temperature between $2.938 \mathrm{~km}$ and $3 \mathrm{~km}$ is $(250+255) / 2$, or $252.5^{\circ} \mathrm{C}$, the corresponding thickness $h$ being $(3-2.938)$, or $0.062 \mathrm{~km}$. Using Eq. 2-2,

$$
Q_{4}^{2}=(2.5)(0.1 \times A)(0.062)(252.5-15)\left(10^{5}\right) \mathrm{J}
$$

or,

$$
Q_{4}^{2}=\left(3.56 \times 10^{5}\right)(X A) \mathrm{J}
$$

The total resource base in $10 \%$ of the geothermal area of a country $=Q_{1}^{2}+$ $Q_{2}^{2}+Q_{3}^{2}+Q_{4}^{2}$. Of this resource $20 \%$ belongs to the hot water and steam classification and $80 \%$ belongs to the dry rock classification.

6. The resource base of a country, in different classes, is given as follows:

$$
\begin{array}{ll}
\text { Class 1: } & Q 1=Q_{1}^{0}+Q_{1}^{1}+Q_{1}^{2} \mathrm{~J} \\
\text { Class 2: } & Q_{2}=Q_{2}^{0}+Q_{2}^{1}+Q_{2}^{2} \mathrm{~J} \\
\text { Class 3: } & Q_{3}=Q_{3}^{0}+Q_{3}^{1}+Q_{3}^{2} \mathrm{~J} \\
\text { Class 4: } & Q_{4}=Q_{4}^{0}+Q_{4}^{1}+Q_{4}^{2} \mathrm{~J}
\end{array}
$$

7. The total resource base of a country is given by

$$
Q=Q 1+Q 2+Q 3+Q 4 J
$$

The total hydrothermal (hot water and steam) resource of a country is $0.20 \mathrm{~J}$.

The total not dry rock resource of a country is $0.80 \mathrm{~J}$. 


\section{Responses to Questionnaire}

Only a few countries responded to the questionnaire with estimates of their resource base. The responses are shown in Table 4 . In many cases the reported resource base is much lower than that estimated in Table 3 by the volumetric heat content method. Such discrepancies are inherent and are expected in estimates of this nature.

Table 4

GEOTHERMAL RESOURCE BASE ESTIMATES PROVIDED BY COUNTRIES IN RESPONSE TO QUESTIONNAIRES

Country

Canada

England

El Salvador

Fiji

Germany, West

Hungary

India

Mexico

New Zealand

Nicaragua

Norway

Spain

Sweden

Taiwan

Total
Resource Base (J)

$1.7 \times 10^{24}$

$8.4 \times 10^{22}$

$1.9 \times 10^{19}$

$3.3 \times 10^{18}$

$1.4 \times 10^{23}$

$5.4 \times 10^{22}$

$8.0 \times 10^{19}$

$1.7 \times 10^{20}$

$1.3 \times 10^{20}$

$5.4 \times 10^{20}$

$1.3 \times 10^{23}$

$5.0 \times 10^{17}$

$1.3 \times 10^{18}$

$8.4 \times 10^{16}$

$2.1 \times 10^{24}$ 
Section 3

ELECTRIC ENERGY CONVERSION

Although the geothermal resource base computed in Section 2 is very large, only a small fraction is suitable for conversion to electric energy. The comparatively low temperature and the energy extraction difficulties result in an overall conversion efficiency that is small relative to that attainable with fossil fuels. The overall conversion efficiency is limited by the first and second laws of thermodynamics and by the inefficiencies associated with energy extraction and conversion to electric power.

To facilitate analytic estimates, the inefficiencies are grouped as follows:

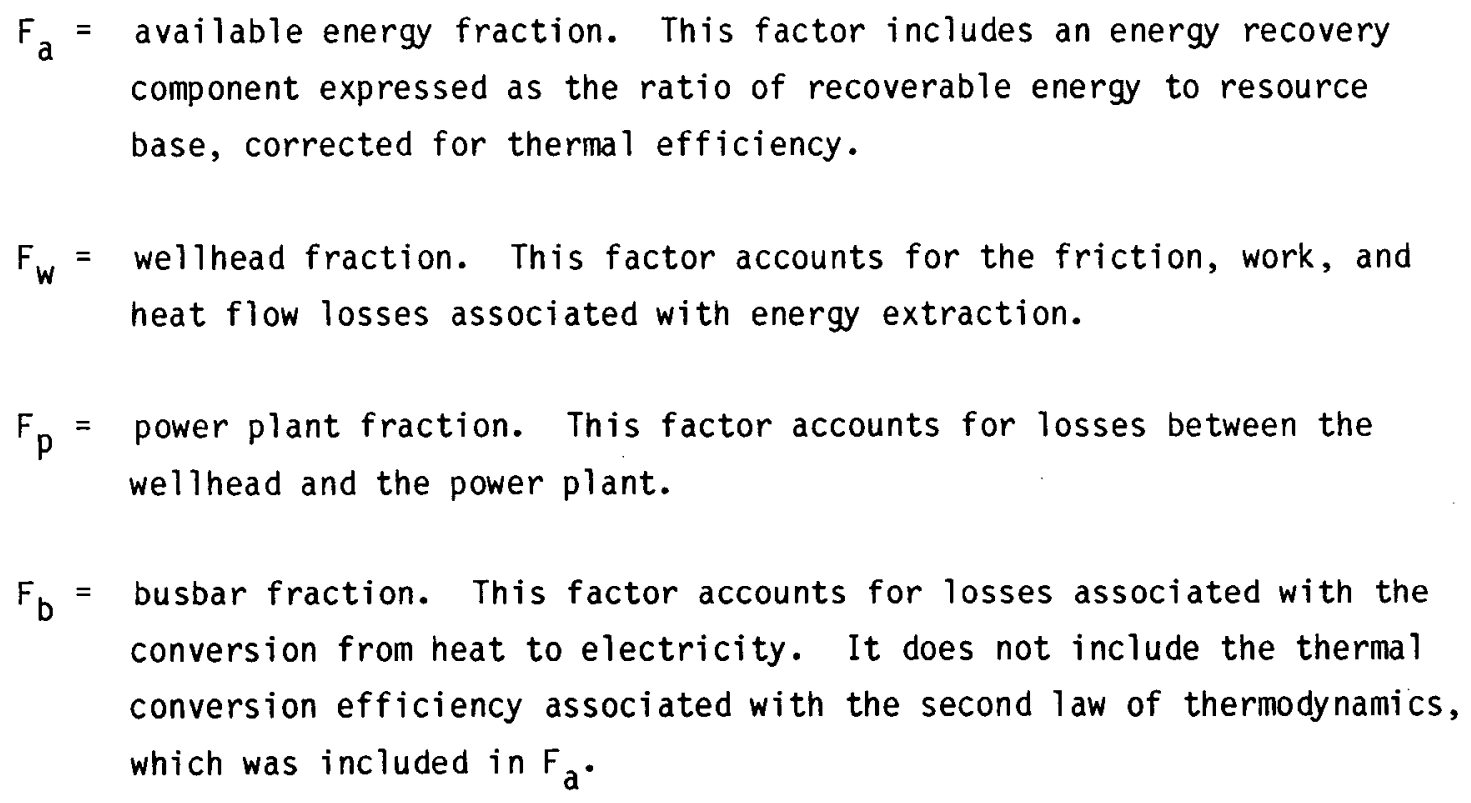

The electric energy delivered to the busbar, $E_{b}$, is calculated by the equation

$$
E_{b}=\left(F_{a}\right)\left(F_{w}\right)\left(F_{p}\right)\left(F_{b}\right) Q
$$

where $Q$ is the resource base. 
For a given geothermal field of volume $V$, the geothermal resource base can be estimated in terms of the average specific heat and the difference between the initial reservoir temperature and the reference datum temperature:

$$
\left(\frac{Q}{V}\right)=C_{v}\left(T_{1}-T_{0}\right)
$$

where $C_{v}=$ volumetric specific heat $\left(2.5 \mathrm{~J} / \mathrm{cm}^{3}{ }^{\circ} \mathrm{C}\right.$, from Section 2)

$\mathrm{T}_{1}=$ initial reservoir temperature

$\mathrm{T}_{0}=$ reference datum temperature $\left(15^{\circ} \mathrm{C}\right.$, from Section 2$)$

\section{ELECTRIC POWER POTENTIAL}

The thermodynamic model of the typical geothermal system, assuming no heat recharge, is illustrated by the absolute temperature-entropy diagram of Figure 2 . The nomenclature of Figure 2 is used in the derivation of equations in this section.

\section{Energy Recovery}

Assuming that $T_{2}$ is the temperature at which the geothermal reservoir production ceases to be economical, the ideal fraction of the energy per unit volume that can be produced is given by

$$
\frac{E_{1-2}}{v}=C_{v}\left(T_{1}-T_{2}\right)
$$

Thus the fraction of the heat that can ideally be recovered is

$$
\frac{E_{1-2}}{Q}=\frac{T_{1}-T_{2}}{T_{1}-T_{0}}
$$

\section{Thermal Efficiency}

The thermal efficiency represents the fraction of the thermal energy, $E_{1-2}$, that can be converted to mechanical or electric energy under the second law of thermodynamics. In Figure 2, the shaded area represents the differential of ideal work, $\delta W k_{i}$. The energy bounded by the same interval of the curve down to $0 K$ is $\delta E$. The Carnot efficiency is 


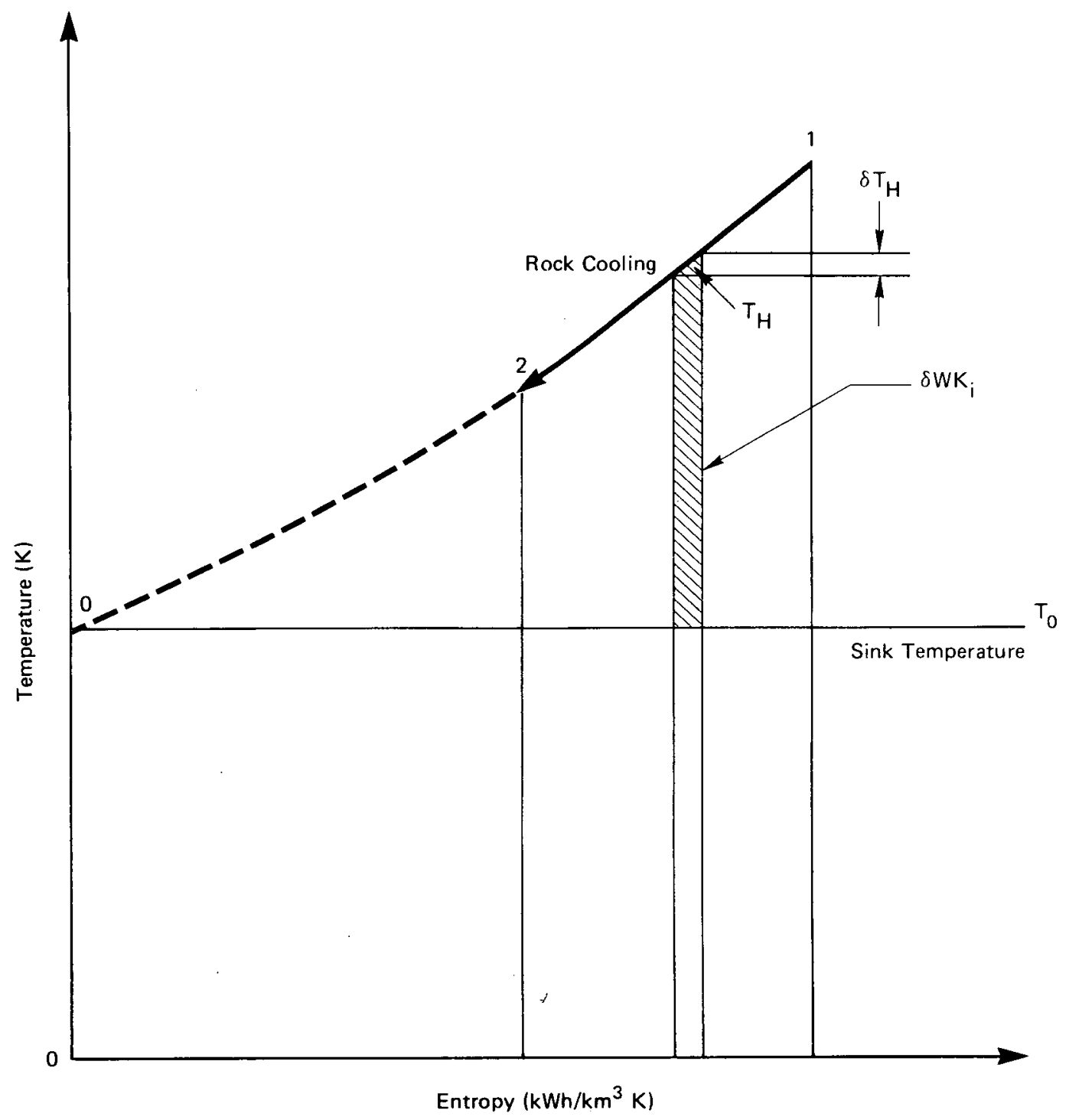

Figure 2 Geothermal reservoir thermodynamics 


$$
\eta_{\text {Carnot }}=\frac{\delta W k_{i}}{\delta E}=1-\frac{T_{0}}{T_{H}}
$$

where $\delta \mathrm{E}=\mathrm{C}_{V} \delta T_{H}$. Integration of $\delta \mathrm{Wk}_{i}$ in Eq. 3-4 between the limits $T_{1} \geq T_{H} \geq T_{2}$ results in

$$
\frac{W k_{i}}{E_{1-2}}=1-\frac{T_{0}}{T_{1-2,1 n}}
$$

where $T_{1-2,1 n}$ is defined by

$$
T_{1-2, \ln }=\frac{T_{1}-T_{2}}{\ln \left(T_{1} / T_{2}\right)}
$$

\section{Available Energy Fraction}

An expression for the fraction of the rock thermal energy that is available for conversion to electric energy, $F_{a}$, is obtained by combining $E q .3-3$ and 3-5.

$$
F_{a}=\frac{W k_{i}}{Q}=\left(\frac{T_{1}-T_{2}}{T_{1}-T_{0}}\right)\left(1-\frac{T_{0}}{T_{1-2,1 n}}\right)
$$

The available energy fraction may also be expressed as functions of the temperature ratios, $a=T_{1} / T_{2}$ and $b=T_{1} / T_{0}$ as

$$
F a=\left[\frac{b}{a}\left(\frac{a-1}{b-1}\right)-\frac{\ln a}{b-1}\right]
$$

Figures 3 and 4 represent Eq. $3-7$ and 3-8, respectively, for $F_{a}=f(a)$ for $b=$ $T_{1} / T_{0}=600 / 288$. $F_{a}$ is the product of the components $E_{1-2} / Q$ from Eq. $3-3$ and $W_{j} / E_{1-2}$ from $E q .3-5$. These components are also graphed in Figure 3 . Figure 4 shows $F_{a}$ as a function of the initial resource temperature, $T_{1}$, and the lower production limit temperature, $\mathrm{T}_{2}$. Both figures show the strong influence of a large $T_{1}$ on $F_{a}$ and a small $T_{2}$ on the available energy fraction. For example, for $\mathrm{T}_{1}=600 \mathrm{~K}$ and $\mathrm{T}_{2}=450 \mathrm{~K}\left(177^{\circ} \mathrm{C}\right)$, the available energy fraction is $\mathrm{F}_{\mathrm{a}}=0.215$. However, for $T_{1}=500 \mathrm{~K}, \mathrm{~F}_{\mathrm{a}}$ (from Figure 4) is reduced by a factor of 2.3 to only 0.093 . Furthermore, if the minimum usable resource temperature $T_{2}$ can be reduced from $177^{\circ} \mathrm{C}$ to $150^{\circ} \mathrm{C}$, Figure 4 shows for $\mathrm{T}_{1}=500 \mathrm{~K}$ that the fraction $\mathrm{F}_{\mathrm{a}}$ increases from 0.093 to 0.136 , improvement by a factor of 1.5 . 


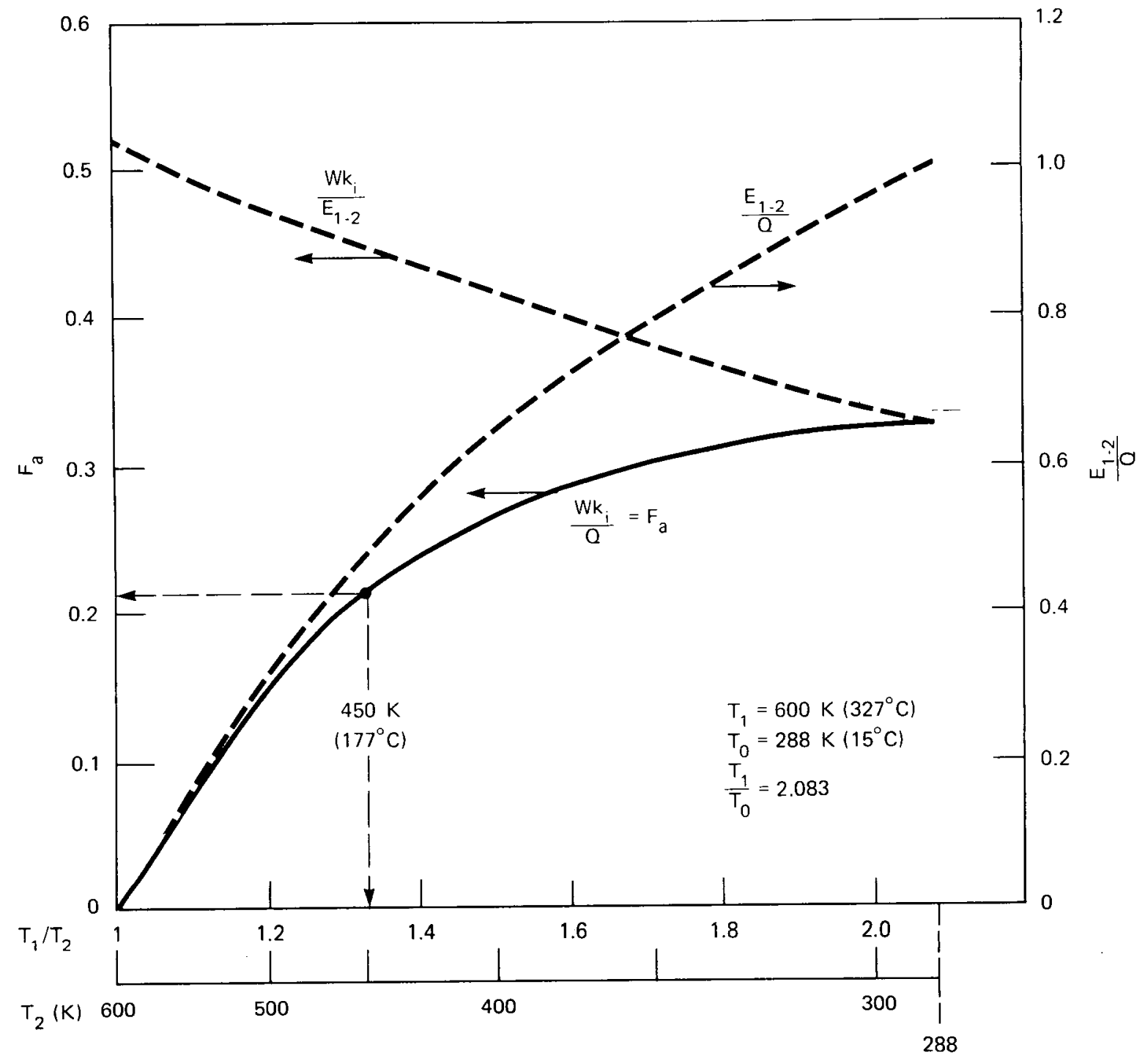

Figure 3 Available energy fraction, $F_{a}$ 


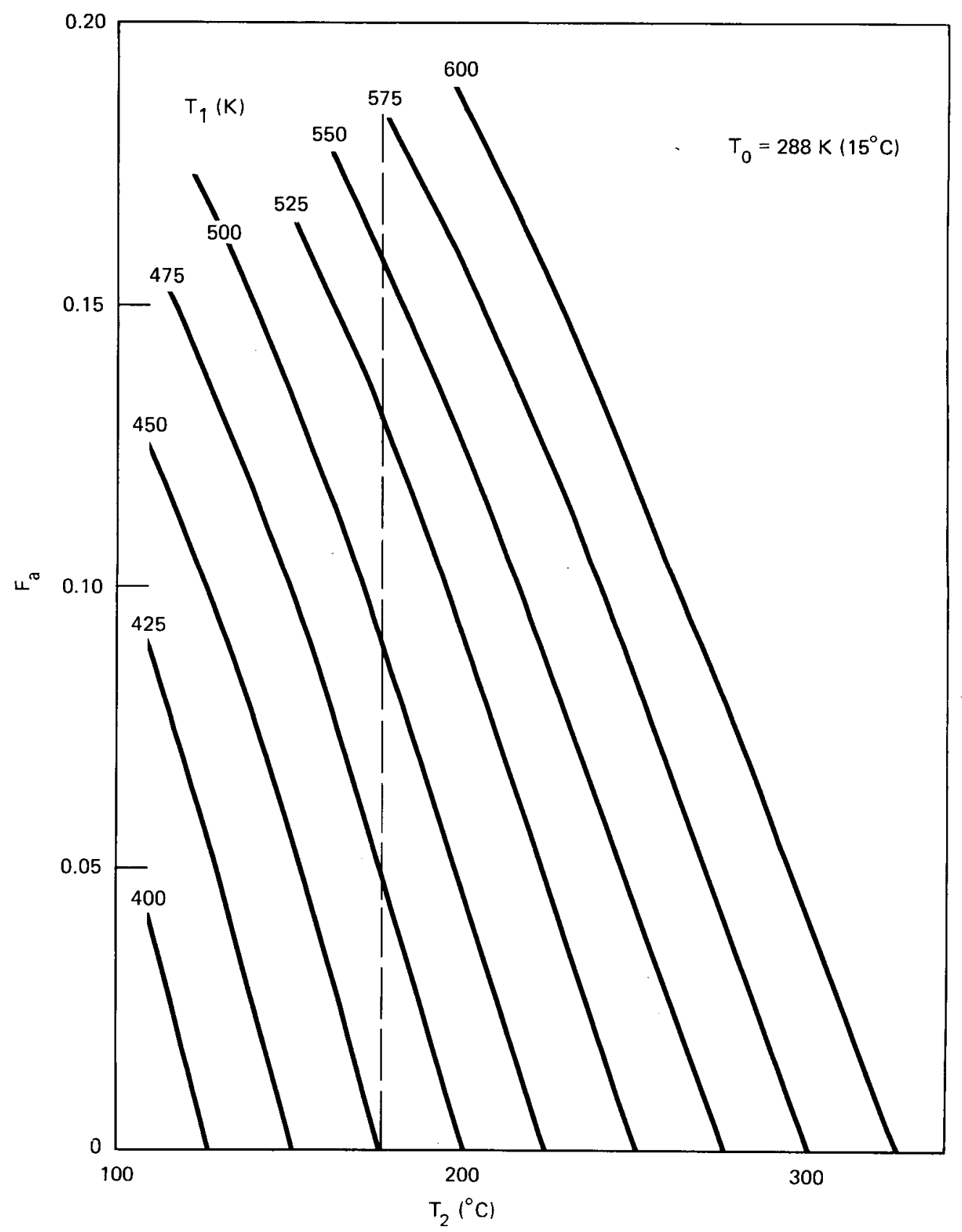

Figure 4 Available energy fraction as a function of initial and final reservoir temperatures 
One further factor affecting the "ideal" available energy fraction is the resource base reference temperature $T_{0}$ shown in Figure 2. If, because of local climatic conditions, the local sink or available coolant temperature, $T_{\infty}$, differs from $T_{0}$, Eq. 3-7 is modified to

$$
F_{a}=\left[\frac{T_{1}-T_{2}}{T_{1}-T_{0}}\right]\left[1-\frac{T_{0}\left(T_{\infty} / T_{0}\right)}{T_{1,2} \ln }\right]
$$

The sensitivity of $F_{a}$ to the ratio $T_{\infty} / T_{0}$ is noted in Figure 5 . A reference point was selected corresponding to an initial reservoir temperature $T_{1}=227^{\circ} \mathrm{C}(550 \mathrm{~K})$ and a lower production limit temperature $T_{2}=127^{\circ} \mathrm{C}$. For $T_{\infty}=T_{0}=15^{\circ} \mathrm{C},(288 \mathrm{~K})$, the available energy fraction $F_{a}$ for the reference case is 0.168 , as noted in Figure 4. The data in Figure 5 show the strong sensitivity of $F_{a}$ to both $T_{1}$ and $T_{2}$ compared with the reference case, but a relatively low sensitivity of $F_{a}$ to $T_{\infty}$.

\section{Wellhead Fraction}

The wellhead fraction, $F_{w}$, accounts for nonuniformity of rock temperature, $T_{2}$, in a large-scale reservoir resulting from long conduction paths in impermeable rock masses that inhibit heat transfer to circulating fluids. It also accounts for fluid friction heat losses in the well bore during production. The wellhead fraction is thus related to the efficiency of mining the available energy, $\left(F_{a}\right) Q$. It can vary with the well and reservoir production techniques employed. Enhanced extraction may be achieved by explosive or hydraulic fracturing or by injection of colder fluids to "sweep" the thermal energy to the well bore. Thus the wellhead fraction, $F_{w}$, in contrast to the available energy fraction, $F_{a}$, which is determined by thermodynamic principles, is very much dependent on judgment and experience. It is also dependent on the type of geothermal reservoir and its porosity, permeability, and rock-size distribution. Based on expected values for these characteristics, values for $F_{W}$ are given below.

\section{Reservoir Type}

Vapor-dominated

Liquid-dominated

Hot dry rock

Geopressured
Wellhead Fraction, $F_{W}$

Range Average
$0.2-0.4$
0.3
$0.2-0.6$
0.4
$0.01-0.15$
0.08
$0.2-0.8$
0.5 


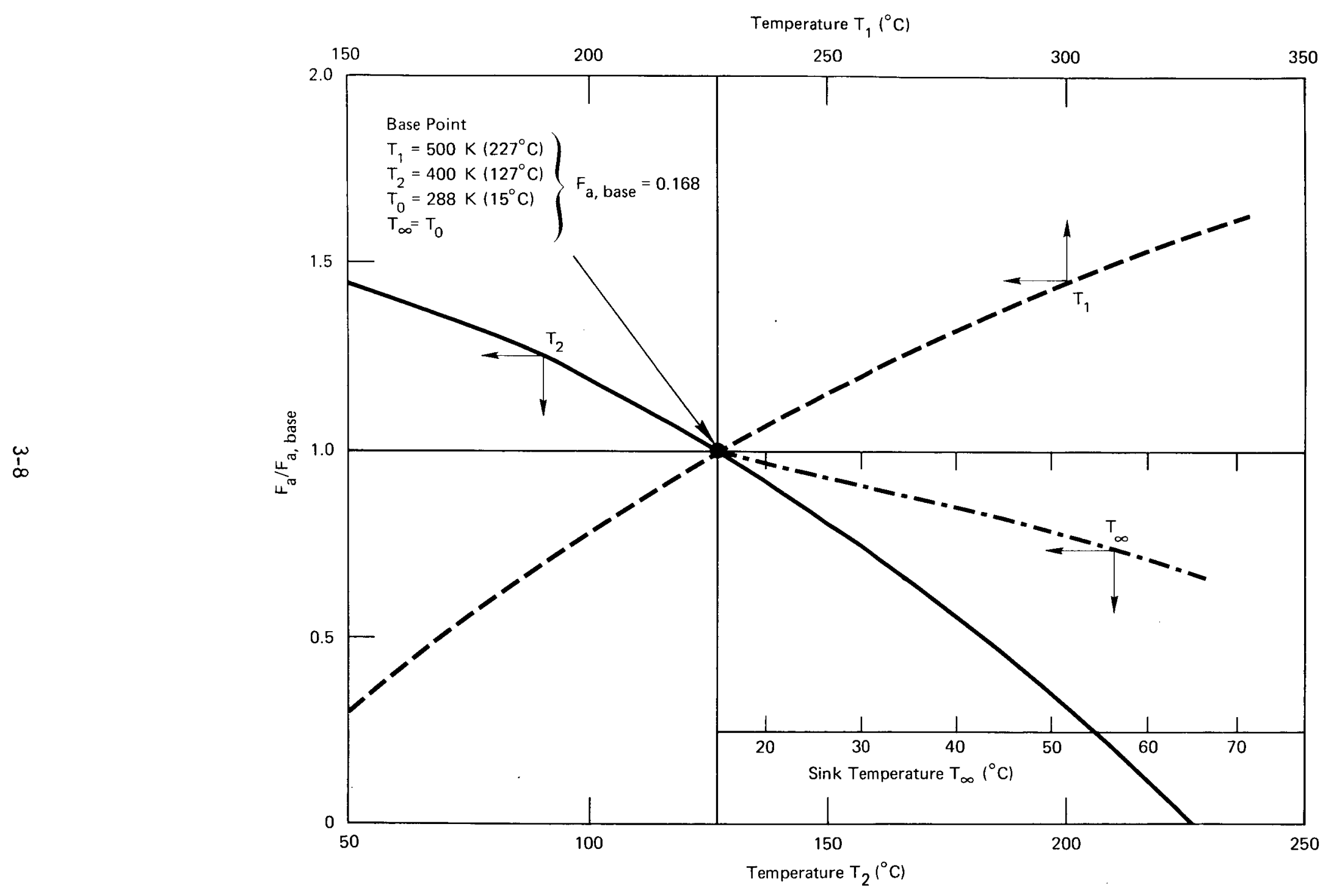

Figure 5 Available energy fraction as a function of reservoir sink temperatures 
Power Plant Fraction

The power plant input fraction, $F_{p}$, considers the piping from wells to power plant, the mode of generation, such as single or multiple flash, heat exchanger losses for binary cycle turbines, and other temperature or pressure losses. Based on experience with vapor-dominated systems at The Geysers (U.S.A.) and with liquid-dominated systems at Wairakei (New Zealand), the following values for the power plant fraction are used.

\begin{tabular}{lc} 
Reservoir Type & $\begin{array}{c}\text { Power Plant } \\
\text { Input Fraction, F }\end{array}$ \\
\hline Vapor-dominated & 0.95 \\
Liquid-dominated* & 0.6 \\
Hot dry rock* & 0.6 \\
Geopressured & 0.6
\end{tabular}

*For either flash steam or binary cycle operation

\section{Busbar Fraction}

The busbar fraction, $F_{b}$, reflects the efficiency of conversion of the net available energy delivered to a turbine (or other expander) to electric power at the busbar. At The Geysers and at Wairakei, the busbar fraction, $F_{b}$, is about 0.72 . This is probably typical of most hydrothermal systems. Additional pumping power requirements will lower the expected value of $F_{b}$, whereas the additional hydraulic energy component of geopressured resources may increase the conversion efficiency. The following values of $F_{b}$ are expected:

\begin{tabular}{lr} 
Reservoir Type & Busbar Fractid \\
\cline { 2 - 2 } & 0.72 \\
Vapor-dominated & 0.72 \\
Liquid-dominated & 0.65 \\
Hot dry rock & 0.75 \\
Geopressured &
\end{tabular}




\section{Overall Efficiency}

In summary, the overall efficiency for producing electric power from a given geothermal reservoir is given by:

$$
\eta_{0}=\frac{E_{b}}{Q}=\left(F_{a}\right)\left(F_{w}\right)\left(F_{p}\right)\left(F_{b}\right)
$$

Typical values are given below for hydrothermal (and geopressured) reservoirs with $\mathrm{T}_{1}=227^{\circ} \mathrm{C}$ and $\mathrm{T}_{2}=177^{\circ} \mathrm{C}$, and for hot dry rock reservoirs with $\mathrm{T}_{1}=302^{\circ} \mathrm{C}$ and $\mathrm{T}_{2}=177^{\circ} \mathrm{C}$.

\begin{tabular}{|c|c|c|c|c|c|}
\hline Reservoir Type & $\mathrm{F}_{\mathrm{b}}$ & $F_{p}$ & $F_{W}$ & $\mathrm{~F}_{\mathrm{a}}$ & $\eta_{0}$ \\
\hline Vapor-domi nated & 0.72 & 0.95 & 0.3 & 0.09 & 0.018 \\
\hline Liquid-dominated & 0.72 & 0.6 & 0.4 & 0.09 & 0.016 \\
\hline Hot dry rock & 0.65 & 0.6 & 0.08 & 0.185 & 0.0058 \\
\hline Geopressured & 0.75 & 0.6 & 0.5 & 0.009 & 0.020 \\
\hline
\end{tabular}

These results show that the overall efficiency for producing electric power from hydrothermal systems is limited to about $2 \%$ of the resource base, primarily because of the small magnitudes of the factors $F_{a}$ and $F_{w}$. Hot rock systems will have a smaller overall efficiency because of the smaller $F_{W}$. Although nature has placed a limit on the value of $F_{a}$, it is possible to increase the value of $F_{w}$ through stimulation. Geopressured resources should have higher conversion factors for comparable operating temperatures $T_{1}$ and $T_{2}$ because of the larger wellhead fraction.

\section{ESTIMATED WORLD POTENTIAL FOR GEOTHERMAL ELECTRICITY}

For the purpose of estimation, only that portion of the geothermal resource base above $150^{\circ} \mathrm{C}$ is considered suitable for electric power production, and it is assumed that the overall conversion efficiency as derived herein applies uniformly. Since current technology is not adequate for the development of petrothermal (hot dry rock) geothermal resources, the estimates herein apply to hydrothermal resources only. For these calculations it is assumed that about $20 \%$ of the resource base is contained in hydrothermal systems. Estimates for countries having the greatest geothermal electric power potential are presented in Table 5 . 
Table 5

HYDROTHERMAL ELECTRICITY POTENTIAL (calculated)

\begin{tabular}{|c|c|c|c|c|}
\hline \multirow[t]{2}{*}{ Country } & \multirow{2}{*}{$\begin{array}{c}\text { Electric } \\
\text { Energy Potential } \\
E_{b}(M W \text { cen })\end{array}$} & \multicolumn{3}{|c|}{$\begin{array}{c}\text { Electric Power Potential } \\
(1000 \mathrm{MW})\end{array}$} \\
\hline & & 1985 & 2000 & 2020 \\
\hline China & 160,000 & 23 & 70 & 140 \\
\hline United States & 150,000 & $\begin{array}{l}23 \\
(6)\end{array}$ & $\begin{array}{c}70 \\
(20)\end{array}$ & 140 \\
\hline Indonesia & 130,000 & $\begin{array}{c}20 \\
(0.03-0.1)\end{array}$ & $\begin{array}{c}60 \\
(0.5-6)\end{array}$ & 120 \\
\hline $\begin{array}{l}\text { Peru } \\
\text { Mexico }\end{array}$ & $\begin{array}{l}86,000 \\
77,000\end{array}$ & $\begin{array}{c}13 \\
12 \\
(0.4-1.4)\end{array}$ & $\begin{array}{c}38 \\
36 \\
(0.5-20)\end{array}$ & $\begin{array}{c}77 \\
72 \\
(4-20)\end{array}$ \\
\hline USSR & 72,000 & 11 & 33 & 65 \\
\hline Chile & 54,000 & 8 & 25 & 49 \\
\hline Ethiopia & 50,000 & 8 & 23 & 45 \\
\hline Ecuador & 30,000 & 5 & 14 & 27 \\
\hline Brazil & 29,000 & 4 & 13 & 26 \\
\hline Turkey & 26,000 & $\begin{array}{c}4 \\
(0.4)\end{array}$ & $\begin{array}{l}12 \\
(1)\end{array}$ & $\begin{array}{c}24 \\
(1.5)\end{array}$ \\
\hline Japan & 24,000 & $\begin{array}{r}4 \\
(2)\end{array}$ & $\begin{array}{c}11 \\
(50)\end{array}$ & 22 \\
\hline Kenya & 24,000 & $\begin{array}{c}4 \\
(0.03)\end{array}$ & $\begin{array}{c}11 \\
(0.06-0.09)\end{array}$ & $\begin{array}{c}22 \\
(0.09-0.15)\end{array}$ \\
\hline Colombia & 23,000 & 4 & 11 & 21 \\
\hline Bolivia & 22,000 & 4 & 10 & 20 \\
\hline Iran & 22,000 & 4 & 10 & 20 \\
\hline Philippines & 20,000 & $\begin{array}{c}3 \\
(0.3)\end{array}$ & 9 & 18 \\
\hline
\end{tabular}

Note: Numbers in parentheses denote estimates by individual countries as presented in Section 5. 
Table 5 (continued)

\begin{tabular}{|c|c|c|c|c|}
\hline \multirow[t]{2}{*}{ Country } & \multirow{2}{*}{$\begin{array}{c}\text { Electric } \\
\text { Energy Potential } \\
E_{b}(M W \text { cen })\end{array}$} & \multicolumn{3}{|c|}{$\begin{array}{c}\text { Electric Power Potential } \\
(1000 \mathrm{MW})\end{array}$} \\
\hline & & 1985 & 2000 & 2020 \\
\hline Venezuela & 12,000 & 2 & 6 & 11 \\
\hline Vietnam & 11,000 & 2 & 5 & 10 \\
\hline Nicaragua & 10,000 & $\begin{array}{l}1.5 \\
(0.2)\end{array}$ & $\begin{array}{c}5 \\
(0.35)\end{array}$ & $\begin{array}{c}9 \\
(0.8)\end{array}$ \\
\hline Italy & 9,900 & 1.5 & $\begin{array}{c}5 \\
(0.8)\end{array}$ & 9 \\
\hline New Guinea & 9,600 & 1.5 & 5 & 9 \\
\hline New Zealand & 9,100 & $\begin{array}{l}1.4 \\
(0.4)\end{array}$ & $\begin{array}{c}4 \\
(1.4)\end{array}$ & $\begin{array}{r}8 \\
(2)\end{array}$ \\
\hline Chad & 8,600 & 1.3 & 4 & 8 \\
\hline Zambia & 7,500 & 1.1 & 3.4 & 7 \\
\hline Guatemala & 7,200 & $(0.1)^{1.1}$ & 3.2 & 6.5 \\
\hline $\begin{array}{l}\text { Korea } \\
\text { Iceland }\end{array}$ & $\begin{array}{l}7,200 \\
6,800\end{array}$ & $\begin{array}{c}1.1 \\
1 \\
(0.15)\end{array}$ & $\begin{array}{c}3.2 \\
3 \\
(0.5)\end{array}$ & $\begin{array}{c}6.5 \\
6 \\
(0.8)\end{array}$ \\
\hline Total & $1.1 \times 10^{6}$ & 169.5 & 502.8 & 998 \\
\hline
\end{tabular}

Note: Numbers in parentheses denote estimates by individual countries as presented in Section 5. 


\section{Calculation Method}

The following equation was used to calculate hydrothermal electric power potential for hydrothermal systems:

$$
E_{b}=0.2 Q \eta_{0}
$$

for which the terms have already been defined. The coefficient 0.2 is the $20 \%$ hydrothermal fraction assumed above.

\section{Sample Calculation}

Calculation of the national geothermal power potential for Iceland illustrates the method used. The resource base used for conversion to electric power is obtained from Table 3 as

$$
\begin{aligned}
Q= & 5.9 \times 10^{21}(\operatorname{class} 3)+3.7 \times 10^{20}(\text { class } 4)= \\
& 6.3 \times 10^{21} \mathrm{~J}
\end{aligned}
$$

$\eta_{0}=0.017$ (overall efficiency, taken as the average of the estimates for liquidand vapor-dominated systems).

The electric potential is given by Eq. 3-11 as

$$
\begin{aligned}
E_{b}= & (0.2)\left(6.3 \times 10^{21}\right)(0.017)= \\
& 2.1 \times 10^{19} \mathrm{~J}=6800 \mathrm{MW} \operatorname{cen}(e)
\end{aligned}
$$

Further assumptions were made to estimate the growth pattern of installed electric power capacity for the years 1985, 2000, and 2020: (1) By the year 2020, about $90 \%$ of $E_{b}$ is assumed committed for use by the year 2100 ; (2) by the year 2000, one-half is assumed committed; and (3) by the year 1985, one-sixth is committed.

Thus, for the total $E_{b}=6800 \mathrm{MW}$ cen(e) in the Iceland example, the installedcapacity timetable becomes: 


$\begin{array}{cc}\text { Year } & \text { Installed Capacity (MW [e]) } \\ 1985 & 1000 \\ 2000 & 3000 \\ 2020 & 6000\end{array}$

The use rate would essentially exhaust the hydrothermal-based $E_{b}=6800 \mathrm{MW}$ cen(e) by the year 2100 , requiring plant replacement after 2020 to maintain power capability, assuming there is no heat recharge to the reservoir. However, it is expected that technology to exploit the remaining $80 \%$ of the energy in the formation rock (the hot dry rock resource base), as well as to drill to deeper depths, will have become available by then.

Similar calculations of the potential for electric power capacity were made for the 28 countries listed in Table 5. Collectively, these countries contain more than $95 \%$ of the worldwide total of $1.2 \times 10^{6} \mathrm{MW}(\mathrm{e})$. The worldwide potential for installed power capacity for the year 2020 is $1.2 \times 10^{6} \mathrm{MW}(e)$. If only about $25 \%$ of this potential is used, perhaps limited by such constraints as local markets, competing energy sources, and site-specific difficulties, the capacity of $250,000 \mathrm{MW}$ (e) would be very impressive, equivalent to a supply of $9 \times 10^{6}$ barrels of oil per day at a conversion efficiency of $42 \%$. These estimates were derived for a conservative abandonment temperature, $T_{2}=177^{\circ} \mathrm{C}$. The dependence of available energy on $T_{2}$ was noted in Figure 5 . If conversion technology permits a lower $\mathrm{T}_{2}$ (e.g., $150^{\circ} \mathrm{C}$ ), the calculated capacity of $250,000 \mathrm{MW}$ (e) would be increased by a factor of 1.45 .

A further observation is of interest. Comparison of the estimated potential with the projections expressed in the questionnaires completed by the various responding countries shows a general expectation of utilizing only a small fraction of the estimated electric power potential. For the Iceland example, the comparison shows the following:

$\begin{array}{ccc}\text { Year } & \begin{array}{c}\text { Questionnaire } \\ \text { Estimate (MW [e]) }\end{array} & \begin{array}{c}\text { Calculated } \\ \text { Potential (MW [e]) }\end{array} \\ 1985 & 150 & 1000 \\ 2000 & 500 & 3000 \\ 2020 & 800 & 6000\end{array}$


The sevenfold difference may reflect a conservative attitude toward the constraints that may limit the anticipated domestic market for electric energy due to the availability of other energy resources, such as hydropower, or site-specific considerations, such as inaccessibility. Japan, which has about four times the energy potential of Iceland $\left(E_{b}=24,000 \mathrm{MW}\right.$ cen[e]), projects a much greater utilization factor.

\section{PROJECTED UTILIZATION}

The projections of electric power utilization as reported in responses to the questionnaire are shown in Table 6. Although the contrast between volumetric calculated and national estimates shown in Table 5 is evident, the growth shown in Table 6 is of the order of 25\% per annum through 1985 and from $11 \%$ to $20 \%$ per annum through 2000. These growth rates could be considered good for this alternative energy source.

ECONOMICS OF GEOTHERMAL POWER

Since many factors affect the cost of geothermal power, and experience is still very limited, it is not possible to generalize about these costs. The major cost factors are:

- Exploration

- Reservoir development

- Geothermal fluid purity and temperature quality

- Site-specific considerations

- Power plant

- Waste geothermal fluid disposal

- Environmental protection

- Operation and maintenance

- Taxes

- Royalties

- Lead time from reservoir discovery to power generation

Many of these cost factors differ in individual countries, and other external factors, such as alternative energy sources, will affect the competitive position of geothermal power. Nevertheless, some observations with regard to experience in the United States may be useful. 
Table 6

\section{ELECTRICITY GENERATING CAPACITY} FROM GEOTHERMAL RESOURCES

(based on questionnaires)

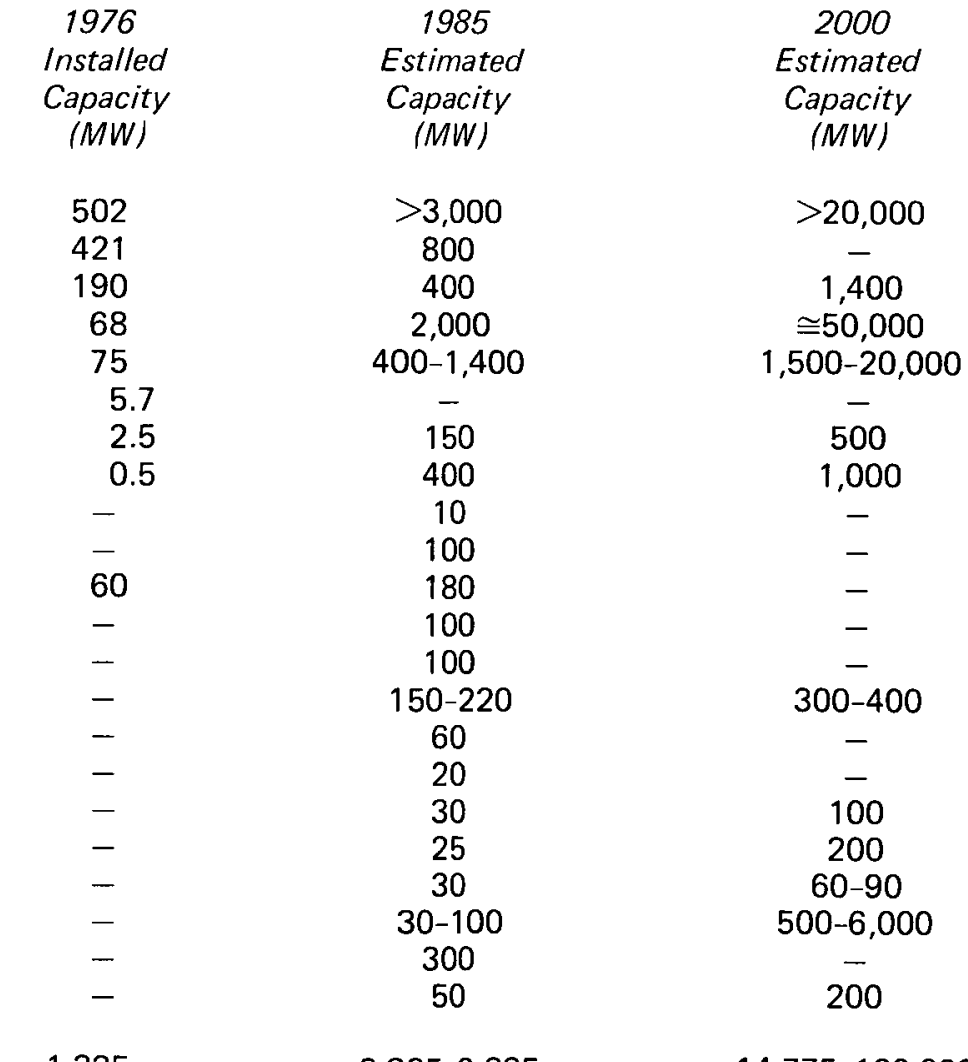

1,325

$14,775-100,000$

Country
United States
Italy
New Zealand
Japan
Mexico
USSR
Iceland
Turkey
Canada
Costa Rica
EI Salvador
Guatemala
Honduras
Nicaragua
Panama
Argentina
Portugal
Spain
Kenya
Indonesia
Philippines
Taiwan
Total

Total 


\section{Energy-Related Cost}

In the United States, geothermal well drilling costs in 1976 dollars ranged from about $\$ 150 / \mathrm{m}$ to $\$ 300 / \mathrm{m}$. The cost of geothermal heat delivered to the power plant at The Geysers (dry steam field) was about $\$ 0.60$ per million Btu. The cost of energy from other hydrothermal systems was projected to be in the range from $\$ 0.60$ to $\$ 0.75$ per million Btu. A better perspective of the relative value of geothermal energy can be gained by comparing it with oil-fired conventional plants. At $\$ 13.50 / \mathrm{bbl}$ for oil, the energy cost would be $\$ 2.50$ per million Btu. Because of the difference in conversion efficiency of the conventional oil-fired plant compared with the geothermal plant, the oil-equivalent energy cost at The Geysers was about $\$ 1.60$ per million Btu, a little more than one-half the price of oil. For the other hydrothermal systems the oil-equivalent energy cost would range from about $\$ 1.60$ to $\$ 2.50$ per million Btu.

\section{Power Plant Cost}

Hydrothermal power plant costs are expected to be about the same as those for oilfired plants; however, the plant cost for dry steam fields may be somewhat lower. Plant costs will vary depending on the conversion cycle and resource type (e.g., flashed steam, binary-cycle, geopressured) but will probably not exceed nuclear power plant costs unless the lower-temperature reservoirs are used.

\section{Operating Cost}

The annual power plant operating and maintenance cost is expected to be about $4.5 \%$ of the plant's capital costs. The operating and maintenance costs associated with reservoir operation are included in the estimated energy costs. 
Section 4

NONELECTRIC USES

\section{PRESENT USES}

Geothermal energy applications other than for electricity generation are broadly categorized as nonelectric. Several factors make nonelectric applications at geothermal resource sites desirable.

- Electricity generation may not be economically feasible at geothermal resources with temperatures below $150^{\circ} \mathrm{C}$.

- For higher-temperature resources where electricity generation is economic, thermal energy uses can reduce the cost of both the electricity and the nonelectric uses.

- Geothermal resources may contain economic quantities of minerals that may possibly be recovered.

- In special circumstances the geothermal resource can be either an important supply of water or an important supply of low-cost energy that can be used to purify water.

The most widespread interest and application of geothermal energy for nonelectric purposes has been as a supply of thermal energy. These thermal energy uses have been at temperatures near the lower end of the scale, which are not suited for economic electricity generation.

Mineral recovery and water purification, although not presently significant on a worldwide basis, could be of very great importance in local situations.

Nonelectric applications, either now or recently in operation, cover a wide spectrum. At one end is the age-old balneological use (therapeutic baths), while at the other end is the use of geothermal energy for cooling, as presently practiced in New Zealand. Applications range from the warming of water for washing livestock stalls to providing the thermal energy requirements of a modern 
pulp and paper mill. Table 7 lists the main nonelectric applications throughout the world.

The estimated total energy use rate represented by Table 7 is about $7000 \mathrm{MW}$ (th). This amount of power is not a large contribution to the total energy use rate of the world. But in some cases it is not an insignificant amount, since for a number of the countries with geothermal potential, it represents more than their total electric power requirements. It is evident that nonelectric applications have been receiving widespread attention, but not the concerted attention necessary for a substantial number of large-scale developments. The degree of utilization in any given country may be related to the availability of geothermal resources and the relative cost of obtaining energy from other sources.

The processes that are most developed with respect to their overall significance as nonelectric applications are space heating, industrial applications, and agricultural applications.

\section{Space Heating}

As illustrated in Table 7 , space heating with geothermal energy is becoming widespread throughout the cooler regions of the world, with sizable applications in a number of countries. The two main classifications of space heating systems are district and individual. Most of the significant applications are in the district heating category. Two noted exceptions, which are individual systems, are at Rotorua, New Zealand; and Klamath Falls, Oregon, U.S.A.

The largest known, and probably the most economical, district heating system is in Reykjavik, Iceland. It supplies a total population of about 90,000 with space and domestic water heating from resources at temperatures varying from $80^{\circ} \mathrm{C}$ to $120^{\circ} \mathrm{C}$. The geothermal water is pumped directly from well to pipeline, held in storage tanks to meet demand, circulated to the consumer at about $80^{\circ} \mathrm{C}$, and then wasted to the municipal sewer system or reinjected. The city is divided into a number of districts, each served by its own pumping station. Water meters are used to determine individual consumer use for billing purposes. The present capacity of the geothermal system is $350 \mathrm{MW}$, with peaking energy demand met from a 35-MW 0i1fired heating plant. The system is presently being expanded by about $25 \%$ to serve an additional 26,000 people. For consumers being supplied by this system, the average cost of heating is about $30 \%$ of what it would be if supplied from an oilfired heating plant. 
Table 7

PRESENT NONELECTRIC APPLICATIONS OF GEOTHERMAL ENERGY

\begin{tabular}{|c|c|c|c|c|c|}
\hline Country & $\begin{array}{c}\text { Locality } \\
\text { (where applicable) }\end{array}$ & $\begin{array}{l}\text { Description } \\
\text { of Application }\end{array}$ & $\begin{array}{c}\text { Associated } \\
\text { Power } \\
(\mathrm{J} / \mathrm{d})^{*}\end{array}$ & Comments & Source \\
\hline Argentina & & Total & Small & Space heating and drying & Questionnaire \\
\hline Chile & & Total & Small & Desalination pilot plant & Questionnaire \\
\hline \multirow[t]{3}{*}{ Czechoslovakia } & & Total & $8.0 \times 10^{12}$ & Space and water heating; mineral baths & Questionnaire \\
\hline & Bohemian Massif & & $2.0 \times 10^{12}$ & & \\
\hline & West Carpathinas & & $5.9 \times 10^{12}$ & & \\
\hline France & & Total & $2 \times 10^{10}$ to $2.1 \times 10^{12}$ & Space and water heating & Questionnaire \\
\hline Germany, West & & Total & $2.3 \times 10^{10}$ & Miscellaneous use in $20-50^{\circ} \mathrm{C}$ range & Questionnaire \\
\hline \multirow[t]{8}{*}{ Hungary } & & Total & $9 \times 10^{12}$ to $9.1 \times 10^{13}$ & & Questionnaire \\
\hline & & Agriculture & $4.6 \times 10^{13}$ & & Boldizsar (1974) \\
\hline & & District heating & $5.0 \times 10^{11}$ & & \\
\hline & & Industry & $2.1 \times 10^{11}$ & & \\
\hline & & $\begin{array}{l}\text { Mineral baths and } \\
\text { swimming pools }\end{array}$ & $3.8 \times 10^{13}$ & & \\
\hline & $\begin{array}{l}\text { Szentes and } \\
\text { various other } \\
\text { localities }\end{array}$ & Greenhouse heating & $1.4 \times 10^{13}$ & $\begin{array}{l}\text { Typical greenhouse vegetables plus paprika; typical } \\
\text { horticulture; } 800,000 \mathrm{~m}^{2} \text { of greenhouse }\end{array}$ & UNESCO (1970) \\
\hline & $\begin{array}{l}\text { Various } \\
\text { localities }\end{array}$ & $\begin{array}{l}\text { Heating and cleaning } \\
\text { animal shelters }\end{array}$ & $1.8 \times 10^{13}$ & $\begin{array}{l}\text { Heating and cleaning milk rooms, cattlestalls, pigsties, } \\
\text { chicken houses; } 25 \text { wells at } 7 \times 10^{11} \mathrm{~J} / \mathrm{d}\end{array}$ & UNESCO (1970) \\
\hline & Szeged & District heating & - & University clinics and 1280 flats, $226,000 \mathrm{~m}^{3}$ & $\begin{array}{l}\text { Einarsson (1973) } \\
\text { Boldizsar (1974) }\end{array}$ \\
\hline
\end{tabular}

Note: Many of the entries on specific applications are from Howard et al., 1975, but original source is cited here.

*The associated power is as reported by the countries in the survey or by the reference. It may be either the power associated with the well flow or the power actually used in the application. 


\section{Table 7 (continued)}

\begin{tabular}{|c|c|c|c|c|c|}
\hline Country & $\begin{array}{l}\text { Locality } \\
\text { (where applicable) }\end{array}$ & $\begin{array}{l}\text { Description } \\
\text { of Application }\end{array}$ & $\begin{array}{l}\text { Associated } \\
\text { Power } \\
(\mathrm{J} / \mathrm{d})^{\bullet}\end{array}$ & Comments & Source \\
\hline \multirow[t]{2}{*}{ Hungary } & Hódmezöväsarhely & $\begin{array}{l}\text { Individual space } \\
\text { heating }\end{array}$ & & Factory and hospital, $172,000 \mathrm{~m}^{3}$ & Einarsson (1973) \\
\hline & Mako & $\begin{array}{l}\text { Individual space } \\
\text { heating }\end{array}$ & & Hospital, $80,000 \mathrm{~m}^{3}$ & Einarsson (1973) \\
\hline \multirow[t]{7}{*}{ Iceland } & & Total & $3.1 \times 10^{13}$ & & \\
\hline & Reykjavik & District heating & $2.8 \times 10^{13}$ & $\begin{array}{l}\text { The system's geothermal resources come from the Reykir } \\
\text { area }\left(3600 \mathrm{~m}^{3} / \mathrm{h} \text { at } 80^{\circ} \mathrm{C}, 170 \mathrm{MW} \text { [th] }\right) \text { and the Reykjavik } \\
\text { area }\left(1700 \mathrm{~m}^{3} / \mathrm{h} \text { at } 119^{\circ} \mathrm{C}, 155 \mathrm{MW} \text { [th] }\right) \text {. Peaking is accom } \\
\text { plished from the system's own fossil-fired peaking power } \\
\text { plant. System started with } 70 \text {-house pilot program in } 1928 \text {. }\end{array}$ & Zoega (1974) \\
\hline & Olafsfjördur & District heating & - & $\begin{array}{l}\text { System serves the housing of } 1000 \text { inhabitants: built in } \\
1944 \text { using only } 48^{\circ} \mathrm{C} \text { water about } 3 \mathrm{~km} \text { away from the } \\
\text { city. In } 1961 \text { deep drilling yielded additional water at } 56^{\circ} \mathrm{C} .\end{array}$ & Einarsson (1973) \\
\hline & Selfoss & District heating & $1.3 \times 10^{12}$ & $\begin{array}{l}\text { System serves } 154,000 \mathrm{~m}^{3} \text { of housing and } 75,000 \mathrm{~m}^{3} \text { of } \\
\text { public, commercial, and industrial buildings (entire city of } \\
2200 \text { ). Boreholes are located } 1.5 \mathrm{~km} \text { away from the city. } \\
\text { System started in } 1948.80 \mathrm{~kg} / \mathrm{s} \text { at } 80^{\circ} \mathrm{C} \text {. }\end{array}$ & Einarsson (1973) \\
\hline & Hveragerdi & District heating & - & $\begin{array}{l}\text { System serves housing in entire city ( } 820) \text { and a therapeutic } \\
\text { spa for } 140 \text { patients; it also supplies heating for } 30,000 \mathrm{~m}^{2} \\
\text { of hothouses. The system was built in } 1953 \text { and utilizes a } \\
180^{\circ} \mathrm{C} \text { geothermal field. }\end{array}$ & Einarsson (1973) \\
\hline & Saudarkrokur & District heating & - & $\begin{array}{l}\text { This system serving the city of } 2000 \text { uses } 70^{\circ} \mathrm{C} \text { water } \\
\text { from nearby boreholes. }\end{array}$ & Einarsson (1973) \\
\hline & Various & Greenhouses & $1.4 \times 10^{12}$ & $\begin{array}{l}\text { Glass greenhouses heated by natural steam and/or hot } \\
\text { water, either directly or with heat exchangers. }\end{array}$ & UNESCO (1970) \\
\hline
\end{tabular}

Note: Many of the entries on specific applications are from Howard et al., 1975, but original source is cited here.

*The associated power is as reported by the countries in the survey or by the reference. It may be either the power associated with the well flow or the power actually used in the application. 


\section{Table 7 (continued)}

\begin{tabular}{|c|c|c|c|}
\hline Country & $\begin{array}{c}\text { Locality } \\
\text { (where applicable) }\end{array}$ & $\begin{array}{l}\text { Description } \\
\text { of Application }\end{array}$ & $\begin{array}{c}\text { Associated } \\
\text { Power } \\
(\mathrm{J} / \mathrm{d})^{*}\end{array}$ \\
\hline \multirow[t]{7}{*}{ Iceland } & Various & Greenhouses & - \\
\hline & Various localities & $\begin{array}{l}\text { Experimental salmon } \\
\text { breeding station }\end{array}$ & $8.8 \times 10^{10}$ \\
\hline & Reykjavik & $\begin{array}{l}\text { Drying fish in } \\
\text { shelf dryers }\end{array}$ & Small \\
\hline & & $\begin{array}{l}\text { Curing of light } \\
\text { aggregate cement } \\
\text { building slabs }\end{array}$ & Small \\
\hline & Reykholar & Drying seaweed & $1.8 \times 10^{12}$ \\
\hline & $\begin{array}{l}\text { Hveragerdi } \\
\text { (Hengill area) }\end{array}$ & $\begin{array}{l}\text { Steam drying of } \\
\text { wood }\end{array}$ & - \\
\hline & Namafjall & $\begin{array}{l}\text { Production of dried } \\
\text { diatomaceous earth } \\
\text { recovered by wet- } \\
\text { mining techniques }\end{array}$ & $3.0 \times 10^{12}$ \\
\hline \multirow[t]{4}{*}{ Italy } & & Total & $2.1 \times 10^{12}$ \\
\hline & Castelnuovo & Greenhouse & $5.0 \times 10^{10}$ \\
\hline & $\begin{array}{l}\text { Galzignano } \\
\text { (Padua) }\end{array}$ & Greenhouse & $3.5 \times 10^{11}$ \\
\hline & Larderello & $\begin{array}{l}\text { Geothermal steam } \\
\text { used for processing } \\
\text { imported ores } \\
\text { (boric acid) }\end{array}$ & $\begin{array}{l}1.3 \times 10^{12} \\
\text { to } \\
1.6 \times 10^{12}\end{array}$ \\
\hline
\end{tabular}

$1 / 3$ flowers, $2 / 3$ vegetables (tomatoes, cucumbers, lettuce); UNESCO (1970) cost, $\$ 0.91 /$ G $(1970)$

Kollafjord experimental fish farm, rearing young salmon Matthiasson (1970) to the smolt stage; $7 \mathrm{l} / \mathrm{s}$ at $70^{\circ} \mathrm{C}$.

Uses excess water from commercial heating system in Lindal (1961a)

Reykjavik during summer in local stock-fish processing center

\section{No details} countries

Lindal (1973)

$\sim 80 \mathrm{l} / \mathrm{s}$ at $100^{\circ} \mathrm{C}$; production of $3600 \mathrm{t} / \mathrm{yr}$ of dry seaweed

Matthiasson (1970)

No details furnished; reported to occur in other places

Lindal (1961a)

Dredging in the lake is done only in the summer, while the plant runs throughout the year; up to $50 \mathrm{t} / \mathrm{h}$ of steam at UNESCO $(1970$

Lindal (1973) $183^{\circ} \mathrm{C} / 10^{5} \mathrm{~Pa}$

Survey

$3000 \mathrm{~m}^{2}$

Barbier (1975)

$20,000 \mathrm{~m}^{2}$

$30 \mathrm{t} / \mathrm{h}$ of steam

Lindal $(1973)$

imported ores

(boric acid)

Note: Many of the entries on specific applications are from Howard et al., 1975. but original source is cited here.

${ }^{*}$ The associated power is as reported by the countries in the survey or by the reference. It may be either the power associated with the well flow or the power actually used in the application. 
Table 7 (continued)

\begin{tabular}{|c|c|c|c|c|c|}
\hline Country & $\begin{array}{c}\text { Locality } \\
\text { (where applicable) }\end{array}$ & $\begin{array}{l}\text { Description } \\
\text { of Application }\end{array}$ & $\begin{array}{c}\text { Associated } \\
\text { Power } \\
(\mathrm{J} / d)^{*}\end{array}$ & Comments & Source \\
\hline Italy & Larderello & $\begin{array}{l}\text { Includes recovery of } \\
\text { substances from the } \\
\text { volatile components } \\
\text { that accompany the } \\
\text { geothermal steam } \\
\text { (boric acid, ammonium } \\
\text { bicarbonate, ammonium } \\
\text { sulfate, and sulfur) }\end{array}$ & - & No longer in operation; large production before 1966 & $\begin{array}{l}\text { Muffler (1973) } \\
\text { Mazzoni (1948) } \\
\text { Garlado (1961) } \\
\text { Lenzi (1964) }\end{array}$ \\
\hline \multirow[t]{8}{*}{ Japan } & & Total & $2.5 \times 10^{14}$ & & Questionnaire \\
\hline & Towada & District heating & $1.8 \times 10^{11}$ & $\begin{array}{l}\text { System constructed in } 1963 \text { with } 11.5-\mathrm{km} \text { transmission } \\
\text { line from Sarukuro springs; } 14 \mathrm{~kg} / \mathrm{s} \text { at } 70^{\circ} \mathrm{C}\end{array}$ & UNESCO (1970) \\
\hline & Okawa & District heating & $2.8 \times 10^{11}$ & $\begin{array}{l}\text { System provides heating for } 3000 \text { houses from a } 12-\mathrm{km} \\
\text { transmission line. } 22 \mathrm{~kg} / \mathrm{s} \text { at } 70^{\circ} \mathrm{C} \text {. }\end{array}$ & UNESCO $(1970)$ \\
\hline & Ukiyama & District heating & $2.2 \times 10^{10}$ & $\begin{array}{l}\text { Water is heated to } 55^{\circ} \mathrm{C} \text { in fossil-fueled boiler. } 12 \mathrm{~kg} / \mathrm{s} \\
\text { at } 40^{\circ} \mathrm{C} \text {. }\end{array}$ & UNESCO (1970) \\
\hline & Aomori & District heating & $2.0 \times 10^{11}$ & $\begin{array}{l}\text { Provides heating for } 34 \text { hotels and } 140 \text { houses, with water } \\
\text { from the Asamushi hot spring area. } 22 \mathrm{~kg} / \mathrm{s} \text { at } 60^{\circ} \mathrm{C} \text {. }\end{array}$ & UNESCO (1970) \\
\hline & $\begin{array}{l}\text { Kannawa, Beppu, } \\
\text { Oita }\end{array}$ & $\begin{array}{l}\text { Confectionery } \\
\text { industry }\end{array}$ & - & $\begin{array}{l}\text { Daily rice-processing capacity } 180 \mathrm{~kg} ; 98^{\circ} \mathrm{C} \text { water, spring } \\
\text { source }\end{array}$ & \\
\hline & Ibusuki & $\begin{array}{l}\text { Brewing and } \\
\text { distilling }\end{array}$ & Small & No details given; one well used. & \\
\hline & $\begin{array}{l}\text { Various } \\
\text { localities }\end{array}$ & $\begin{array}{l}\text { Greenhouse } \\
\text { heating }\end{array}$ & $2.7 \times 10^{11}$ & $\begin{array}{l}\text { Horticulture (various species); vegetables (tomatoes, } \\
\text { cucumbers, papayas, melons, bananas, eggplants); } 3 \text { types } \\
\text { of greenhouse: glass, plastic, vinyl; } 15,528 \mathrm{~m}^{2} \text { of } \\
\text { greenhouse }\end{array}$ & UNESCO (1970) \\
\hline
\end{tabular}

Note: Many of the entries on specific applications are from Howard et al., 1975, but original source is cited here.

*The associated power is as reported by the countries in the survey or by the reference. It may be either the power associated with the well flow or the power actually used in the application. 
Table 7 (continued)

\begin{tabular}{|c|c|c|c|c|c|}
\hline Country & $\begin{array}{l}\text { Locality } \\
\text { (where applicable) }\end{array}$ & $\begin{array}{l}\text { Description } \\
\text { of Application }\end{array}$ & $\begin{array}{l}\text { Associated } \\
\text { Power } \\
(\mathrm{J} / d)^{*}\end{array}$ & Comments & Source \\
\hline Japan & $\begin{array}{l}\text { Minami-Izu } \\
\text { Shizuoka }\end{array}$ & $\begin{array}{l}\text { Heating poultry } \\
\text { houses, drying } \\
\text { droppings }\end{array}$ & $1.4 \times 10^{11}$ & $\begin{array}{l}\text { Yoshisawa poultry yard, heating below floor with pipes; } \\
\text { drying droppings from } 8000 \text { chickens; } 115^{\circ} \mathrm{C} \text { water at } \\
300 \mathrm{l} / \mathrm{min}\end{array}$ & \\
\hline & $\begin{array}{l}\text { Ueda, Beppu, } \\
\text { Oita }\end{array}$ & $\begin{array}{l}\text { Heating poultry } \\
\text { houses, drying } \\
\text { droppings }\end{array}$ & Small & Nakamura poultry yard, 1600 chickens & \\
\hline & $\begin{array}{l}\text { Minami-lzu } \\
\text { Shizuoka }\end{array}$ & $\begin{array}{l}\text { Alligator and } \\
\text { crocodile breeding }\end{array}$ & $8.4 \times 10^{11}$ & $\begin{array}{l}\text { Altigators and crocodiles, } 20 \text { species; geothermal water } \\
\text { mixed with cold to attain } 28-32^{\circ} \mathrm{C} \text {; water } 105^{\circ} \mathrm{C} \text { at } \\
2000 \mathrm{l} / \mathrm{min}\end{array}$ & \\
\hline & $\begin{array}{l}\text { Hokkaido and } \\
\text { Kogashima } \\
\text { prefectures }\end{array}$ & Eel breeding & Small & Uses water from hot springs & UNESCO (1970) \\
\hline \multirow[t]{3}{*}{$\stackrel{t}{i}$} & $\begin{array}{l}\text { Shikabe, } \\
\text { Hokkaido }\end{array}$ & $\begin{array}{l}\text { Experimental } \\
\text { breeding station }\end{array}$ & $8.8 \times 10^{11}$ & $\begin{array}{l}\text { Hokkaido hot-water hatching center, eels and carp; } 70 \mathrm{l} / \mathrm{s} \\
\text { at } 70^{\circ} \mathrm{C}\end{array}$ & \\
\hline & $\begin{array}{l}\text { Shikabe, } \\
\text { Hokkaido }\end{array}$ & $\begin{array}{l}\text { Production of salt } \\
\text { from sea water }\end{array}$ & - & No longer in operation, formerly about $150 \mathrm{t} / \mathrm{yr}$. salt & UNESCO $(1970)$ \\
\hline & & $\begin{array}{l}\text { Extraction of sulfur } \\
\text { from volcanic gases }\end{array}$ & - & Unsophisticated operation that has become uneconomical & UNESCO (1970) \\
\hline \multirow[t]{4}{*}{ New Zealand } & & Total & $1.7 \times 10^{13}$ & & Questionnaire \\
\hline & Kawerau & $\begin{array}{l}\text { Pulp and paper } \\
\text { processing and a } \\
\text { small amount of } \\
\text { electric power } \\
\text { generation }\end{array}$ & $\begin{array}{l}8.8 \times 10^{12} \\
\text { to } \\
1.1 \times 10^{13}\end{array}$ & $\begin{array}{l}\text { Geothermal energy delivered to mills by } 36,287 \mathrm{~kg} / \mathrm{h} \text { of } \\
1.4 \times 10^{6} \mathrm{~Pa} \text { steam and } 145,149 \mathrm{~kg} / \mathrm{h} \text { of } 6.9 \times 10^{5} \mathrm{~Pa} \\
\text { steam, obtained by flashing wet steam at the well bore; } \\
181,436 \mathrm{~kg} / \mathrm{h} \text { of steam }\end{array}$ & UNESCO (1970) \\
\hline & Rotorua & Veneer factory & - & No details given & UNESCO (1970) \\
\hline & Rotorua & Timber drying in kilns & - & No details given & UNESCO $(1970)$ \\
\hline
\end{tabular}

Note: Many of the entries on specific applications are from Howard et al., 1975, but original source is cited here.

*The associated power is as reported by the countries in the survey or by the reference. It may be either the power associated with the well flow or the power actually used in the application. 
Table 7 (continued)

\begin{tabular}{|c|c|c|c|c|c|}
\hline Country & $\begin{array}{l}\text { Locality } \\
\text { (where applicable) }\end{array}$ & $\begin{array}{l}\text { Description } \\
\text { of Application }\end{array}$ & $\begin{array}{c}\text { Associated } \\
\text { Power } \\
(\mathrm{J} / \mathrm{d})^{*}\end{array}$ & Comments & Source \\
\hline \multirow[t]{3}{*}{ New Zealand } & Rotorua & $\begin{array}{l}\text { Individual space } \\
\text { heating of homes plus } \\
\text { space cooling of a } \\
\text { business }\end{array}$ & - & $\begin{array}{l}\text { Over } 700 \text { geothermal bores serving many individual appli- } \\
\text { cations. City consists of seven areas, three of which have } \\
\text { approximately } 80 \text { bores at a useful average of } 5.1 \times 10^{10} \mathrm{~J} / \mathrm{d} \text {, } \\
70 \text { bores at a useful average of } 6.3 \times 10^{10} \mathrm{~J} / \mathrm{d} \text {, and } 50 \text { bores } \\
\text { at a useful average of } 2.0 \times 10^{11} \mathrm{~J} / \mathrm{d} \text {, respectively. }\end{array}$ & $\begin{array}{l}\text { UNESCO (1970) } \\
\text { UNESCO (1974) }\end{array}$ \\
\hline & $\begin{array}{l}\text { Various } \\
\text { localities }\end{array}$ & Greenhouse heating & - & $\begin{array}{l}\text { Mushrooms (soil is sterilized and heated by using geothermal } \\
\text { fluids directly); tree nursery (seedlings); tomatoes }\end{array}$ & UNESCO (1970) \\
\hline & Taupo & $\begin{array}{l}\text { Pig-farm heating, } \\
\text { sterilizing; drying } \\
\text { sheep crutchings; dry- } \\
\text { ing wool cuttings }\end{array}$ & Small & $\begin{array}{l}\text { Geothermal steam is used to cook and sterilize garbage } \\
\text { feed; warm piggery floors to } 85^{\circ} \mathrm{F} \text {; hose pens; sterilize } \\
\text { and concentrate waste manure; dry sheep crutchings; } \\
\text { boil sheet cuttings. }\end{array}$ & Keer et al. (1961) \\
\hline
\end{tabular}

Note: Many of the entries on specific applications are from Howard $\epsilon t$ al., 1975, but original source is cited here.

* The associated power is as reported by the countries in the survey or by the reference. It may be either the power associated with the well flow or the power actually used in the application. 
Table 7 (continued)

\begin{tabular}{|c|c|c|c|c|c|}
\hline Country & $\begin{array}{l}\text { Locality } \\
\text { (where applicable) }\end{array}$ & $\begin{array}{l}\text { Description } \\
\text { of Application }\end{array}$ & $\begin{array}{c}\text { Associated } \\
\text { Power } \\
(\mathrm{J} / \mathrm{d})^{*}\end{array}$ & Comments & Source \\
\hline Nicaragua & & Total & $2 \times 10^{12}$ to $16.7 \times 10^{12}$ & & Questionnaire \\
\hline Peru & & Total & Small & Desalination tests in progress & Questionnaire \\
\hline \multirow[t]{3}{*}{ Philippines } & & Total & $4.2 \times 10^{11}$ & & \\
\hline & Tiwi, Albay & $\begin{array}{l}\text { Production of salt } \\
\text { from seawater }\end{array}$ & $<2.2 \times 10^{11}$ & $\begin{array}{l}\text { Seawater brought } 3 \mathrm{~km} \text { to plant; three grades of salt } \\
\text { produced }\end{array}$ & $\begin{array}{l}\text { Howard et al. } \\
\text { (1975) }\end{array}$ \\
\hline & Tiwi, Albay & Grain drying & $<2.2 \times 10^{11}$ & $\begin{array}{l}\text { Palay drying time cut to } 10 \mathrm{~min} \text { from } 4-8 \mathrm{~h} \text {; model } \\
\text { being tested }\end{array}$ & $\begin{array}{l}\text { Howard et al. } \\
(1975)\end{array}$ \\
\hline Taiwan & & Total & $5.0 \times 10^{10}$ & & Survey \\
\hline \multirow[t]{2}{*}{ Turkey } & & Total & $1.7 \times 10^{10}$ & & \\
\hline & Kizildere & Greenhouse heating & $1.7 \times 10^{10}$ & $\begin{array}{l}\text { Hot water passes through radiator; air forced through } \\
\text { radiator heats greenhouse; } 3.7 \times 10^{12} \mathrm{~J} \text { per } 6 \text { months. }\end{array}$ & $\begin{array}{l}\text { Howard et al. } \\
(1975)\end{array}$ \\
\hline \multirow[t]{2}{*}{ United States } & & Total & $1.5 \times 10^{12}$ & & ERDA (1976) \\
\hline & Boise, Idaho & District heating & $8.0 \times 10^{11}$ & $\begin{array}{l}\text { This system, which continues to serve about } 200 \text { houses } \\
\text { and } 10-12 \text { businesses ( } 1970) \text {, is one of the oldest district } \\
\text { heating systems. It was built during the } 1890 \text { s. New system } \\
\text { being expanded for space heating. }\end{array}$ & Wells (1971) \\
\hline
\end{tabular}

Note: Many of the entries on specific applications are from Howard et al., 1975, but original source is cited here.

"The associated power is as reported by the countries in the survey or by the reference. It may be either the power associated with the well flow or the power actually used in the application. 
Table 7 (continued)

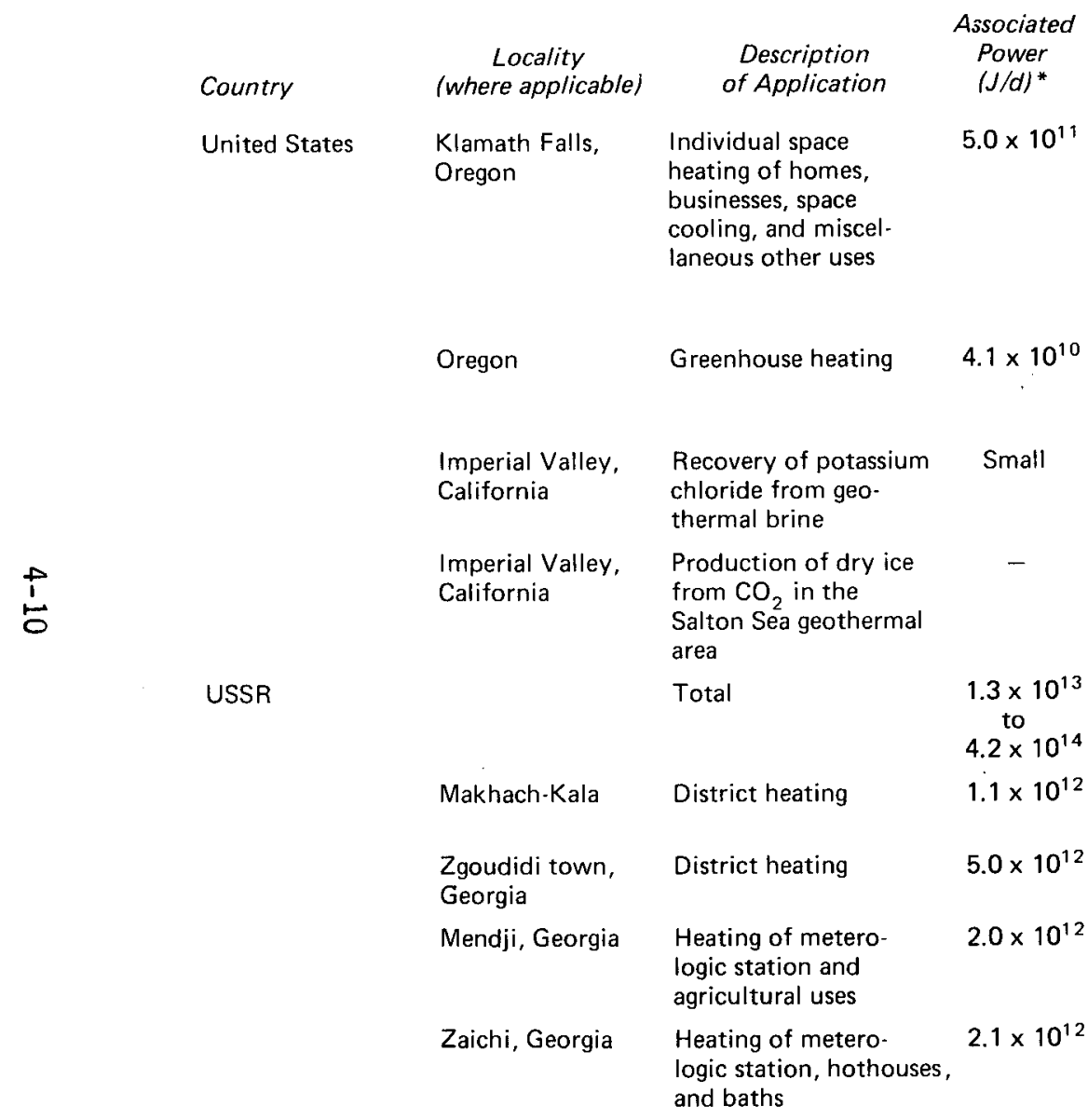

Comments

Source

Space heating of homes is generally accomplished with several homeowners sharing a well and using downhole heat exchange systems. Presently 468 residences are heated geothermally. Some commercial installations withdraw the geothermal fluid, use it in heat exchangers, and draw the geothermal fluid, use it in heat exchangers,
discharge the waste water into the sewer system or a discharge the

Steel-framed fiberglass greenhouse; $70^{\circ} \mathrm{F}$ year-round, automatic environmental control system; heat exchanger tomatoes; $2415 \mathrm{~m}^{2}$ of greenhouse.

Head (1970)

Muffler (1973)

Muffler (1973)

Several districts are suppiied, one of which has 15,000 inhabitants. $23 \mathrm{~kg} / \mathrm{s}$ at $63^{\circ} \mathrm{C}$ plus $70 \mathrm{~kg} / \mathrm{s}$, plus others

UNESCO (1970)

UNESCO (1970)

UNESCO (1970)

UNESCO (1970)

Note: Many of the entries on specific applications are from Howard et al., 1975, but original source is cited here.

*The associated power is as reported by the countries in the survey or by the reference. It may be either the power associated with the well flow or the power actually used in the application. 
Table 7 (continued)

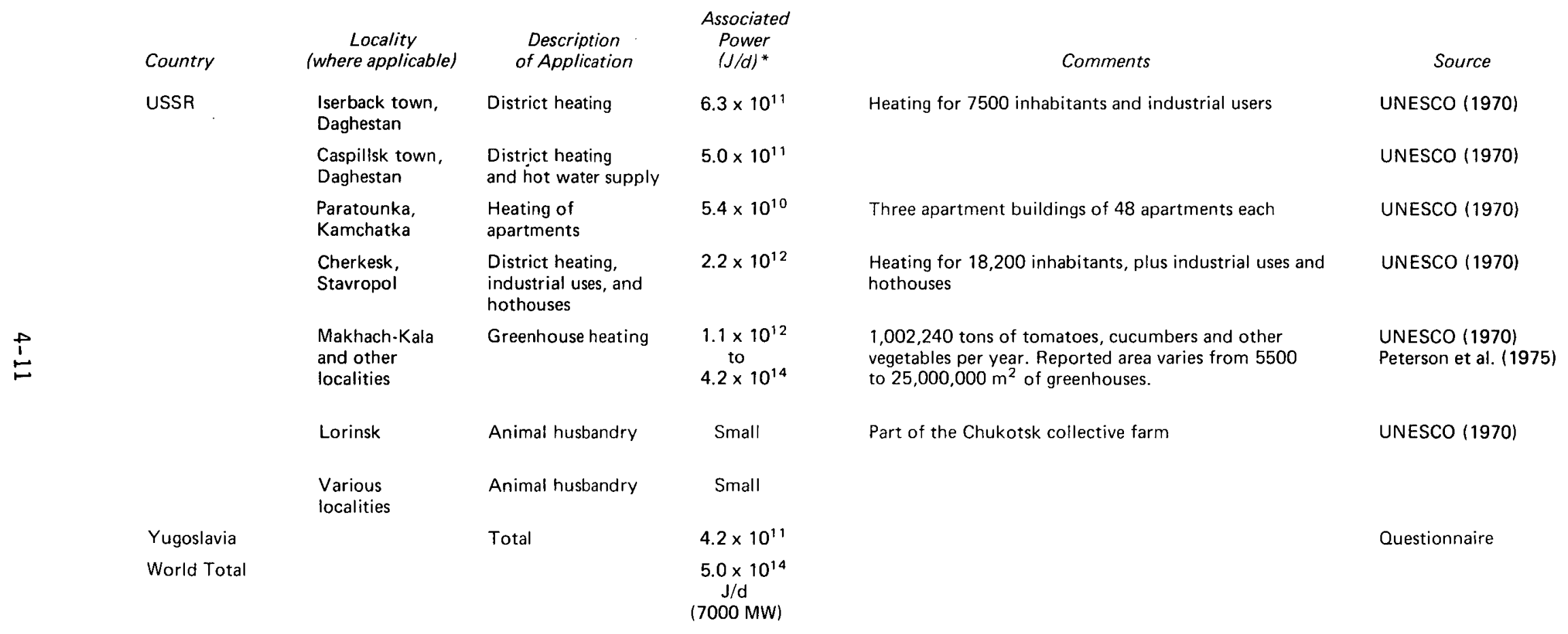

Note: Many of the entries on specific applications are from Howard et al., 1975, but original source is cited here.

*The associated power is as reported by the countries in the survey or by the reference. It may be either the power associated with the well flow or the power actually used in the application. 
A number of unique systems exist in one or more of the many geothermal space heating applications. For example, in Russia, France, and the United States, electrically powered heat pumps are used in conjunction with geothermal resources to provide either base or peak heating. In Rotorua, New Zealand, cooling with geothermal energy is accomplished using an absorption system.

\section{Industrial Applications}

The pulp, paper, and wood processing plant of Tasman Pulp and Paper Company, located in Kawerau, New Zealand, was the first major industrial development to utilize geothermal energy for heating purposes. The plant site was chosen because of the availability of geothermal energy. The geothermal energy was first used for timber drying in kilns and for wood preparation in 1957, then for the pulp and paper operation in 1962. Steam at pressures of $6.9 \times 10^{5}$ and $1.4 \times 10^{6} \mathrm{~Pa}$ is used for the various heating requirements of the plant. This system has been operating quite satisfactorily and has a power output of about 100-125 MW. A unique feature of the plant is the standby 10-MW noncondensing turbo-alternator, which is given priority for the geothermal steam in the event of a failure in the external electric power supply.

The production of diatomaceous earth at Namafjall, Iceland, is a significant development for geothermal energy in industrial applications. It is not only a large-scale application, it is also an example of the way in which geothermal energy can make a process economical, when it could not otherwise be justified.

Following the discovery of rich deposits of high-grade diatomite on the bottom of Lake Myvatn, technical and economic studies indicated that only by the use of potentially cheap geothermal energy from the nearby Namafjall high-temperature geothermal field could the recovery and drying of the diatomite be competitive with conventional diatomite production from comparatively dry land.

In late 1967 operation of the diatomaceous earth plant began with a production rate of $12,000 \mathrm{t} / \mathrm{yr}$. In 1970 the plant expanded and production increased to $24,000 \mathrm{t} / \mathrm{yr}$. The geothermal fluid, obtained from the wellhead at $250^{\circ} \mathrm{C}$ and a pressure of at least $3.9 \times 10^{6} \mathrm{~Pa}$, is flashed to provide saturated steam at $1 \times 10^{6}$ Pa pressure that is transmitted to the plant. In the plant, the energy is used for drying, slurry heating, space heating, and de-icing storage reservoirs during winter. The total consumption during the winter amounts to about $50 \mathrm{t} / \mathrm{h}$ of the $1 \times 10^{6} \mathrm{~Pa}$ steam. 
Another use that is indicative of the wide variety of applications for geothermal energy is the present use of relatively low-temperature waters to thaw large areas of ground to allow mining in certain regions of the USSR.

\section{Agricultural Applications}

The three primary agricultural applications of geothermal energy are greenhouses, animal husbandry, and aquaculture. By far the most extensive use of geothermal fluids is in greenhouses. This application is most common in regions where growing seasons are short and greenhouses are necessary to meet the local demand for vegetables. In Iceland most of the tomatoes, lettuce, cucumbers, and other fresh vegetables are grown with geothermal energy supplying the heating energy. Similarly, the USSR and Hungary have extensive greenhouse applications that use geothermal energy. The animal husbandry and aquaculture applications are much more restricted than are the greenhouses. Hungary has the only large application of geothermal energy for animal husbandry, and it is expected that this will not be a significant, widespread use for geothermal energy in the future. There are only a relatively few small aquaculture applications that use geothermal energy at this time.

\section{POTENTIAL USES}

Many other processes may be adapted to directly utilize geothermal energy. Because geothermal energy is thermal energy at a relatively low temperature (compared with that available from fossil fuels) and its direct use is limited to an area of several tens of kilometers surrounding the geothermal site, there are two main factors regarding the energy use in the particular process that must be considered when evaluating potential industrial uses. The first of these is the minimum temperature range of the geothermal fluid that can satisfy the potential use. The second is the energy-cost-intensiveness of the potential application (i.e., the energy cost to produce the product relative to the value of the product itself).

If the required temperature and the resource temperatures are compatible and the process is energy-cost-intensive, then there is a good chance that the use of geothermal energy in the process will be economical. The location of the raw materials with respect to the geothermal resource is also an important factor. If the process is not energy-cost-intensive, it probably will not be a good candidate for geothermal energy use, regardless of the temperature, unless the energy consumption in the particular industry is very high and there is an excellent 
match in the location of the process, the raw materials, and the geothermal resource.

Figure 6 illustrates the approximate minimum required temperatures of geothermal fluids for a variety of applications. The figure shows the temperature requirements of both the present applications and a number of potential applications. In general, as the geothermal fluid temperature increases, the application heat transfer equipment costs decrease and the operation becomes more economical. Exceptions to this occur when the increased temperature is accompanied by increased corrosion and scaling in the system and when the increased temperature causes more complicated design problems, such as pressurization of the entire system.

Table 8 lists the energy-intensiveness of a variety of industrial processes, and Table 9 lists processes that have had detailed studies of their potential for use of geothermal energy. Production of heavy water and fresh water appear to be very good potential uses of geothermal energy, the first depending on the need, and the latter on the coincidence of the need and the geothermal resources. A number of the other energy-intensive uses in Table 8 have been examined for their potential for geothermal energy use. For many, the potential for geothermal use appears good. However, for a number of processes the electricity requirements are also quite large and the steam requirements could be generated quite cheaply in a combined system with electricity generation. For these, geothermal energy may not be competitive unless the resource is also adequate for electricity generation.

PROBLEMS IN NONELECTRIC USES

Although nonelectric uses are potentially feasible for a wide variety of resource qualities, these uses are not without problems. Some of the problems are due to the use itself, while others are due to the type of resource available. One of the most readily recognized problems with direct applications, and the one that most significantly separates nonelectric from electric applications, is the fact that direct uses are necessarily restricted to relatively small areas centering on the resource. Electricity generated from geothermal resources, remote from load centers, can be tied into a grid system. But in direct applications, the thermal energy cannot be economically transported more than a few tens of kilometers, depending on the nature and size of the energy requirement. 


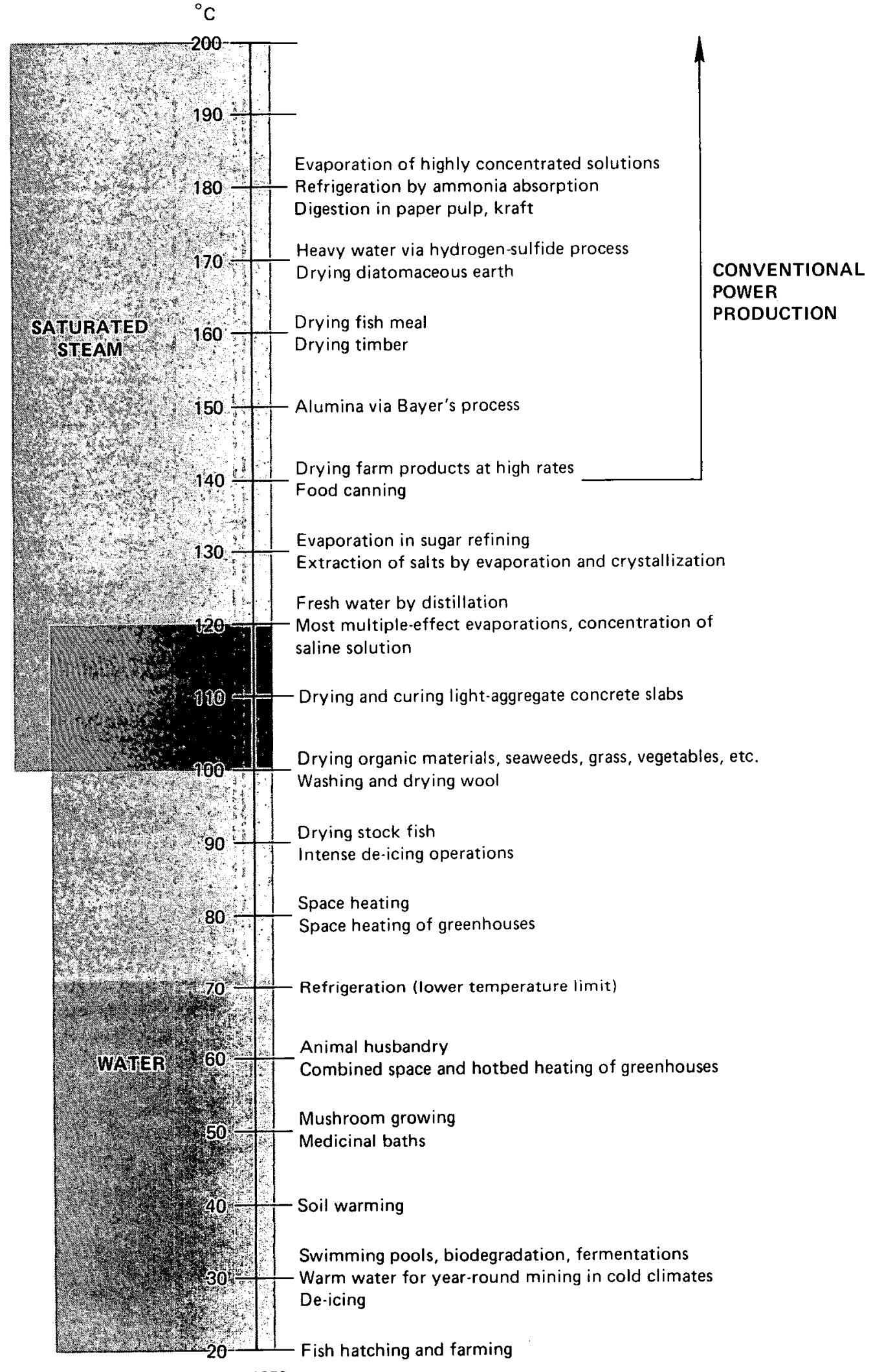

Source: The Unesco Press, 1973.

Figure 6 Approximate geothermal fluid temperatures for nonelectric applications 
Table 8

\section{ENERGY REQUIREMENTS IN RELATION TO PRODUCT VALUE FOR A WIDE VARIETY OF PROCESSES}

Product and Process

Heavy water by hydrogen sulfide process

Ascorbic acid

Viscose rayon

Lactose

Acetic acid from wood via Suida process

Ethyl alcohol from sulfite liquor

Ethyl alcohol from wood waste

Ethylene glycol via chlorohydrin

Casein

Ethylene oxide

Basic magnesium carbonate

$35 \%$ hydrogen peroxide

$85 \%$ hydrogen peroxide from $35 \% \mathrm{H}_{2} \mathrm{O}_{2}$

Solid caustic soda via diaphragm cells

Acetic acid from wood via solvent extraction

Alumina via Bayer process

Ethyl alcohol from molasses

Beet sugar

Sodium chlorate

Kraft pulp

Dissolving pulp

Sulfite pulp

Aluminum sulfate

Synthetic ethyl alcohol

Calcium hypochloride, high-test

Acetic acid from wood via Othmer process

Ammonium chloride

Boric acid

Soda ash via Solvay process

Cottonseed oil

Natural sodium sulfate

Cane sugar refining

Ammonium nitrate

Ammonium sulfate

Fresh water from seawater by distillation

\section{Steam \\ Product \\ Steam per Unit \\ Requirements Value Product Value \\ ( $\mathrm{kg}$ steam $/ \mathrm{kg}$ product) $(\not / \mathrm{kg}) \quad(\mathrm{kg}$ steam $/ \$$ value)}

$\begin{array}{ccr}10,000 & 6,614 & 151 \\ 250 & 551 & 45 \\ 70 & 165 & 42 \\ 40 & 31 & 130 \\ 35 & 22 & 159 \\ 22 & 15 & 142 \\ 19 & 15 & 123 \\ 13 & 29 & 45 \\ 13 & 123 & 10 \\ 11 & 33 & 33 \\ 9 & 24 & 37 \\ 9 & 40 & 23 \\ 4.75 & - & - \\ 8 & 7 & 121 \\ 7.5 & 22 & 34 \\ 7 & 7 & 106 \\ 7 & 15 & 45 \\ 5.75 & 22 & 26 \\ 5.5 & 20 & 28 \\ 4.2 & 13 & 32 \\ 4.2 & - & - \\ 3.5 & 13 & 26 \\ 3.5 & 4 & 79 \\ 3 & 15 & 20 \\ 3.5 & 7 & 50 \\ 2.75 & 22 & 13 \\ 2.75 & 13 & 21 \\ 2.25 & 11 & 20 \\ 2 & 3.3 & 60 \\ 2 & 22 & 9 \\ 1.8 & 3.3 & 54 \\ 1.67 & 22 & 8 \\ 1.5 & 8 & 20 \\ 0.17 & 3.3 & 5 \\ 0.08 & 0.04 & 227 \\ & & \end{array}$

Source: B. Lindal (1973). 
Table 9

POTENTIAL INDUSTRIAL USES OF GEOTHERMAL ENERGY

Application

\begin{abstract}
Production of heavy water
\end{abstract}

Production of fresh water

Recovery of chemicals
Description

Production of heavy water by the hydrogen sulfide-water isotope exchange process

Production of fresh water from either seawater or geothermal fluids

Recovery of salt from seawater using geothermal energy

Multiproduct recovery from seawater

Multiproduct recovery from seawater and/or geothermal brine

Multiproduct recovery from geothermal brine

Multiproduct recovery from geothermal brine

Comment

References

Good process for geothermal energy use since huge quantities of steam are required per dollar of product value; appears economical under proper conditions.

Promising process because of large quantities of energy required, but requires geographic coincidence of fresh water and geothermal sources. Use of geothermal fluid itself is interesting because of the already high enthalpy of the liquid.

Found uneconomical. Also, novel scheme using glacial ice.

Reference is largely a review of the possibilities and points out the more prominent candidates for recovery.

Reference discusses a sea-chemical complex and emphasizes extrac tion of common salt, calcium chloride, potassium chloride, and bromine from geothermal brine in the Reykanes peninsula of Iceland. Also considers magnesium chloride and soda ash production.

Production of minerals and fresh water from the geothermal brines in the Imperial Valley, U.S.A.

References discuss the possibilities of future chemical extraction from geothermal fluids in the USSR; bromine and iodine are emphasized but some reference is also given to alkaline metals, boron, lithium, and a few trace elements.
UNESCO (1970), Valfells et al. (1969), Valfells (1959)

Bodvarsson (1961), UNESCO (1970), Rex (1968, 1971), Barnea (1971), Guiza (1974)

Lindal (1961b, 1967)

Ludviksson and Lindal (1966)

UNESCO (1970)

UNESCO (1970)

UNESCO (1970) 


\begin{tabular}{|c|c|c|c|}
\hline Application & Description & Comment & References \\
\hline $\begin{array}{l}\text { Production of } \\
\text { alumina }\end{array}$ & $\begin{array}{l}\text { Production of alumina } \\
\text { from bauxite via } \\
\text { Bayer process }\end{array}$ & $\begin{array}{l}\text { Not in practice at time of study } \\
\text { due to unfavorable market and } \\
\text { raw material conditions. }\end{array}$ & Lindal (1961a) \\
\hline $\begin{array}{l}\text { Production of } \\
\text { sulfur }\end{array}$ & $\begin{array}{l}\text { Processing of sulfur } \\
\text { ore with geothermal } \\
\text { energy }\end{array}$ & $\begin{array}{l}\text { Investigation still under way as } \\
\text { of time of reference. }\end{array}$ & UNESCO (1970) \\
\hline Mining & $\begin{array}{l}\text { Use of geothermal } \\
\text { energy in mining } \\
\text { operations }\end{array}$ & $\begin{array}{l}\text { Energy is required to ease } \\
\text { mining operations and allow } \\
\text { year-round mining in permafrost } \\
\text { regions of USSR. }\end{array}$ & UNESCO (1970) \\
\hline \multirow[t]{2}{*}{ Refrigeration } & $\begin{array}{l}\text { Freeze-drying of } \\
\text { foodstuffs using } \\
\text { geothermal energy }\end{array}$ & $\begin{array}{l}\text { Good potential use since the cost } \\
\text { of conventional energy may be } \\
45 \% \text { of the processing cost in } \\
\text { freeze-drying operations. }\end{array}$ & Ludviksson. (1970) \\
\hline & $\begin{array}{l}\text { Cooling with } \\
\text { liquefied air }\end{array}$ & $\begin{array}{l}\text { Process has been proposed a } \\
\text { number of times, but no details } \\
\text { have been given. Presumably, } \\
\text { absorption refrigeration from geo- } \\
\text { thermal energy would be used to } \\
\text { decrease the power required in a } \\
\text { conventional air liquefaction } \\
\text { process. }\end{array}$ & \\
\hline
\end{tabular}

Source: Howard (1975).

In nonelectric applications a very significant factor, in addition to the size of the thermal energy demand and the distance between the resource and the market, is the annual load factor. Nonelectric geothermal systems are characterized by having substantially greater initial capital costs and lower operating costs than most conventional systems; consequently, when the annual load factor is low and the large capital investment is effectively used for only a small part of the year, the desirability of such a system markedly decreases. Space heating, one of the most potentially significant nonelectric uses, has quite low annual load factors in many of the heavily populated regions of the world. Iceland, which has enjoyed much success with geothermal space heating, requires space heating throughout the year and has a relatively high annual load factor of about 0.50 to 0.60. In comparison, a typical load factor for space heating systems operating in New York is about 0.2 to 0.3 . 
In addition, since geothermal energy requires large capital investments, it is very sensitive to interest-rate changes.

One technological problem may also substantially limit nonelectric applications at higher temperatures: as the geothermal fluid temperature increases, its tendency to cause corrosion and scaling also increases significantly. The usual surface heat exchangers that would normally be used in such applications are quite sensitive to corrosion and scaling, and an economical solution other than wasteful steam flashing has not yet been found.

Because nonelectric uses will almost exclusively utilize geothermal resources that are water-dominated and at the lower end of the temperature spectrum, the overall enthalpy drop per unit mass flow of geothermal fluid can be relatively small and the total flow rate of fluid can be very large. Often this fluid is not compatible with surface disposal and reinjection must be considered. Widespread experience with reinjecton of the magnitude required in such applications does not exist, and substantial study and experimentation are required before the design for such disposal systems will be routine.

\section{ECONOMICS}

The economic feasibility of a nonelectric geothermal system depends on a number of factors. Hypothetical economic evaluations are open to question until all factors have been examined and practical experience provides realistic data. Economic data in the literature are most prevalent for space heating systems and show that geothermal systems can be economical relative to conventional systems under the right circumstances. The following two examples illustrate the comparison. Zoega (1974) reports the unit prices for heating in Reykjavik with different fuels as presented here in Table 10. Purvine (1975) reports that the cost of heating a college campus at Klamath Falls, Oregon, with geothermal energy is about one-tenth the cost that it would be if conventional fuel were used: $0.46 \mathrm{U} . \mathrm{S} . \not / \mathrm{m}^{2}$ of floor space for the geothermal system compared with $4.6 \mathrm{U} . \mathrm{S} . \not / \mathrm{m}^{2}$ of floor space for the conventional system. These costs may be on the low side, since the cost of capital was not included. The apparent inconsistency of greater economic advantage of geothermal energy in $\mathrm{Klamath}$ Falls compared with Reykjavik is a result of the college campus being a single concentrated load with small distribution charges, while about $60 \%$ of the Reykjavik heating cost results from distribution. 
Table 10

\section{COST FOR SPACE HEATING WITH VARIOUS FUELS IN REYKJAVIK, ICELAND}

Source

Geothermal district heating

Light fuel oil

Heavy fuel oil

Electricity (hydro)

Surplus electricity (night)
Cost (U.S. $\not / k W h)$

0.53

2.18

1.04

1.44 to 2.91

0.91

Source: Zoega (1974).

OUTLOOK FOR THE FUTURE

The total amount of geothermal energy contained in the geothermal resource base of the world was shown to be large. How rapidly this large resource will be developed throughout the various countries is not really evident at this time. However, recent price increases of fossil fuels in world markets should stimulate such development.

Since many of the nonelectric applications can use low-temperature resources, the total resource base given in Table 11 may be used for such applications. A large fraction of the energy requirements of most of the world's present societies could conceivably be satisfied with thermal energy from geothermal resources. There are, however, many factors that must be evaluated to determine the feasibility of application at each resource site. Although space here does not permit a full discussion of these details, there are a number of factors that generally indicate the desirability of applications:

Space Heating: The area to be heated must be close to the resource site; the higher the annual load factor the better; the institutional barriers of having district heating systems must be removed.

Industry: The energy use and/or energy-intensiveness of the process must be high; the raw materials source and resource location must be compatible; if large amounts of electricity are required in addition to thermal energy, the geothermal resource should also be able to produce electricity. 
Table 11

\section{PROJECTED NONELECTRIC APPLICATIONS OF GEOTHERMAL ENERGY (calculated)}

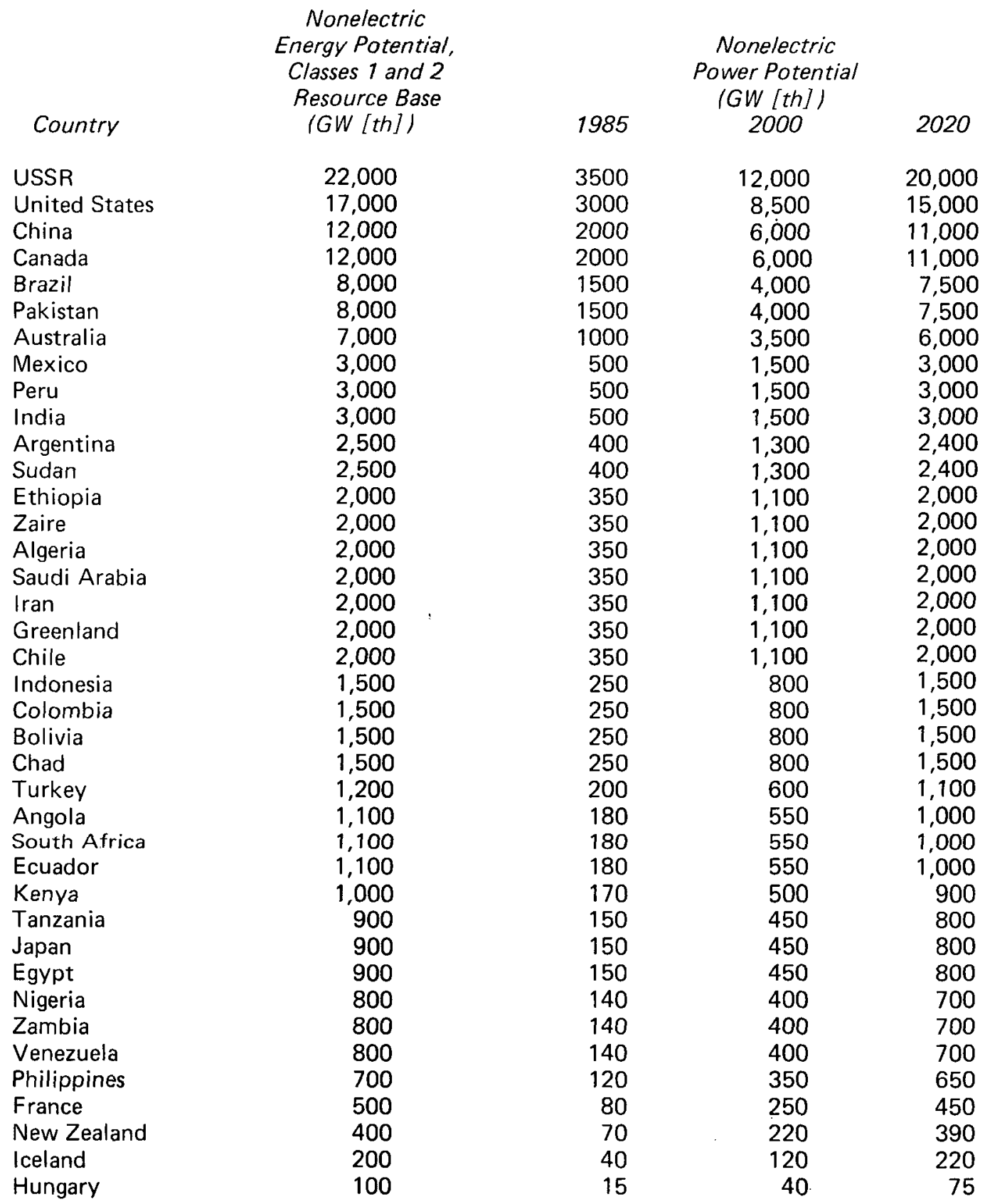


Agriculture: The main applications are greenhouse heating and aquaculture. Both of these appear to be growing in significance and have very good potential applications in countries at higher latitudes. The main limitation to such applications will come from competition with the huge quantities of waste heat available from large fossil- or nuclear-fueled electricity generating plants. The geothermal systems might have a location advantage, and in many small countries they would not have the power stations to compete with.

Drilling depth required to recover the resource is also a very important factor. The maximum economically allowable depth is dependent on many variables, one of which is the resource temperature. In general, the maximum economically allowable depth increases as the resource temperature increases, and al though the resource base for all classes was considered to extend to $3 \mathrm{~km}$, only classes 3 and 4 could be expected to be economically recoverable at depths approaching $3 \mathrm{~km}$.

An estimate of the worldwide nonelectric use potential that is limited by the resource can be made in a manner similar to that for electricity generation in Section 2. The estimate has an additional degree of uncertainty compared with that for electricity generation, however, because the overall conversion efficiency varies not only with the resource type and the other items considered for electricity generation but also with the particular type of process. For example, a specific process may extract a temperature drop of only $20 \mathrm{~K}$ from a geothermal fluid originally at $273 \mathrm{~K}\left(100^{\circ} \mathrm{C}\right)$, while an integrated process facility may extract 40-50 K. The estimate can be made by developing individual conversion factors similar to those developed in Section 3. However, since an estimate is to be made for the actual direct thermal use and not the thermodynamically maximum use, energy qualities rather than available energy quantities are of interest. With the nomenclature of Section 2, the factors are estimated as follows and denoted by 'to distinguish them from the values for electricity generation.

Available Energy Fraction, $F_{a}^{\prime}$ : The hot rock fraction is the energy obtained from cooling the resource from $T_{1}$ to $T_{2}$ relative to the resource base.

$$
F_{a}^{1}=\frac{E_{1-2}}{Q}=\frac{T_{1}-T_{2}}{T_{1}-T_{0}}
$$


Wellhead Fraction, $F_{W}^{\prime}$ : The wellhead fraction is estimated to be the same for both electric and nonelectric applications.

$$
F_{W}^{\prime} \cong F_{W}
$$

Heating Plant Input Fraction, $F_{h p i}^{\prime}$ : The pressure drops that occur in the piping and flashing represent very small losses for most direct thermal processes, and $F_{h p i}$ is estimated at 0.90 to 0.95 .

Heating Plant Conversion Fraction, $F_{h p c}$ : The heating plant conversion efficiency depends very much on the type of plant. For an extensive district heating system with a large amount of distribution piping, $F_{\text {hpc }}$ may be slightly less than 0.8 , while for a compact processing plant it might be 0.95 .

With these factors and the data presented in Table 3 , the geothermal nonelectric potential for the world is estimated at $4.2 \times 10^{23} \mathrm{~J}=1.45 \times 10^{8} \mathrm{MW} \operatorname{cen}(\mathrm{th})$. This estimate is based on the following:

- Only classes 1 and 2 of the resource base are considered for nonelectric uses (although some class 3 resources are now being used for such).

- Only $20 \%$ of the total resource base will be considered as being convertible by present technology.

- On the average, $T_{1}=340 \mathrm{~K}\left(67^{\circ} \mathrm{C}\right)$ and $T_{2}=330 \mathrm{~K}\left(57^{\circ} \mathrm{C}\right)$ for the $\mathrm{Class} 1$ resource; for the Class 2 resource, $T_{1}=400 \mathrm{~K}\left(127^{\circ} \mathrm{C}\right)$ and $T_{2}=360 \mathrm{~K}$ $\left(87^{\circ} \mathrm{C}\right.$ ). (The $T_{2}$ values are different for the two resources because of differences in the processes that would use the resources.) With $T_{0}=$ $288 \mathrm{~K}\left(15^{\circ} \mathrm{C}\right)$, these yield $F_{i c}^{\prime}=0.19$ and 0.36 for classes 1 and 2 respectively.

- Mean values of $\eta_{0}=(0.19)(0.4)(0.9)(0.9)=0.05$ and $(0.36)(0.4)(0.9)(0.9)=0.12$ will be used as averages for resource classes 1 and 2 , respectively. 
The estimate of worldwide potential for installed nonelectric capability for the years 1985,2000 , and 2020 becomes $25 \times 10^{6}, 80 \times 10^{6}$, and $120 \times 10^{6} \mathrm{MW}$ (th), respectively.

In comparison, Table 12 illustrates the questionnaire results for projections of nonelectric applications of geothermal energy in the years 1985, 2000, and 2020. Using the above methodology to estimate the potential for just the countries listed in Table 12 gives totals of $7 \times 10^{6}, 20 \times 10^{6}$, and $30 \times 10^{6} \mathrm{MW}(\mathrm{th})$ for 1985, 2000, and 2020, respectively. These values are two or three hundredfold larger than the estimates listed in Table 12 from the questionnaire, where the totals are about $2 \times 10^{4}, 6 \times 10^{4}$, and $14 \times 10^{4} \mathrm{MW}(\mathrm{th})$ for the same years. The large difference between the estimated potential and the estimated projected use is expected and reflects the following: (1) much of the $\mathrm{Class} 1$ and $\mathrm{Cl}$ ass 2 resource base may not be economically recoverable because of its occurrence at the greater depths $(2$ to $3 \mathrm{~km})$ considered in the resource base, which is particularly true of the Class 1 resource; (2) limits on the anticipated domestic market for thermal energy near the resource; (3) availability of inexpensive low-temperature thermal energy (e.g., waste thermal energy from electric power plants and solar energy; and (4) site-specific difficulties such as mountainous terrain, land-use restrictions, and recreational use of the resource.

The estimates of the potential and projected uses reveal that a number of countries are planning substantial contributions from geothermal energy through nonelectric applications, but these contributions represent less than $1 \%$ of the total potential. The use estimates indicate roughly a two- to fourfold increase by 1985 , a six- to tenfold increase by 2000 , and up to a twentyfold increase by 2020, compared with the present use as illustrated in Table 12 . It is evident that in the next several decades there will be significant progress, developments, and applications in this area. Countries that have promising geothermal resources but at present have not investigated nonelectric applications of geothermal energy would be well advised to consider this resource. 
- Only classes 1 and 2 of the resource base are considered for nonelectric uses (although some class 3 resources are now being used for such).

- Only $20 \%$ of the total resource base will be considered as being convertible by present technology.

- On the average, $T_{1}=340 \mathrm{~K}\left(67^{\circ} \mathrm{C}\right)$ and $T_{2}=330 \mathrm{~K}\left(57^{\circ} \mathrm{C}\right)$ for the class 1 resource; for the Class 2 resource, $T_{1}=400 \mathrm{~K}\left(127^{\circ} \mathrm{C}\right)$ and $T_{2}=360 \mathrm{~K}$ $\left(87^{\circ} \mathrm{C}\right)$. (The $T_{2}$ values are different for the two resources because of differences in the processes that would use the resources.) With $\mathrm{T}_{0}=$ $288 \mathrm{~K}\left(15^{\circ} \mathrm{C}\right)$, these yield $\mathrm{F}_{i \mathrm{c}}^{\prime}=0.19$ and 0.36 for $\mathrm{classes} 1$ and 2 respectively.

- Mean values of $0=(0.19)(0.4)(0.9)(0.9)=0.05$ and $(0.36)(0.4)(0.9)(0.9)=0.12$ will be used as averages for resource classes 1 and 2 , respectively.

The estimate of worldwide potential for installed nonelectric capability for the years 1985, 2000, and 2020 becomes $25 \times 10^{6}, 80 \times 10^{6}$, and $120 \times 10^{6} \mathrm{MW}(\mathrm{th})$, respectively.

In comparison, Table 12 illustrates the questionnaire results for projections of nonelectric applications of geothermal energy in the years 1985, 2000, and 2020. Using the above methodology to estimate the potential for just the countries listed in Table 12 gives totals of $7 \times 10^{6}, 20 \times 10^{6}$, and $30 \times 10^{6} \mathrm{MW}$ (th) for 1985,2000 , and 2020, respectively. These values are two or three hundredfold larger than the estimates listed in Table 12 from the questionnaire, where the totals are about $2 \times 10^{4}, 6 \times 10^{4}$, and $14 \times 10^{4} \mathrm{MW}(\mathrm{th})$ for the same years. The large difference between the estimated potential and the estimated projected use is expected and reflects the following: (1) much of the Class 1 and Class 2 resource base may not be economically recoverable because of its occurrence at the greater depths $(2$ to $3 \mathrm{~km}$ ) considered in the resource base, which is particularly true of the Class 1 resource; (2) limits on the anticipated domestic market for thermal energy near the resource; (3) availability of inexpensive low-temperature thermal energy (e.g., waste thermal energy from electric power plants and solar energy; and (4) site-specific difficulties such as mountainous terrain, land-use restrictions, and recreational use of the resource. 
The estimates of the potential and projected uses reveal that a number of countries are planning substantial contributions from geothermal energy through nonelectric applications, but these contributions represent less than $1 \%$ of the total potential. The use estimates indicate roughly a two- to fourfold increase by 1985 , a six- to tenfold increase by 2000 , and up to a twentyfold increase by 2020, compared with the present use as illustrated in Table 12 . It is evident that in the next several decades there will be significant progress, developments, and applications in this area. Countries that have promising geothermal resources but at present have not investigated nonelectric applications of geothermal energy would be well advised to consider this resource.

Table 12

PROJECTED NONELECTRIC APPLICATIONS OF GEOTHERMAL ENERGY IN THE YEARS 1985, 2000, AND 2020 (results from questionnaires)

\begin{tabular}{|c|c|c|c|c|}
\hline \multirow[b]{2}{*}{ Country } & \multirow{2}{*}{$\begin{array}{l}\text { Temperature Range } \\
\text { of Expected Use }\left({ }^{\circ} \mathrm{C}\right)\end{array}$} & \multicolumn{3}{|c|}{ Projected Nonelectric Use in Each Year $(\mathrm{J} / \mathrm{d})$} \\
\hline & & 1985 & 2000 & 2020 \\
\hline \multirow[t]{2}{*}{ Canada } & $50-100$ & $8.4 \times 10^{11}$ & - & - \\
\hline & $20-50$ & $4.2 \times 10^{10}$ & - & - \\
\hline \multirow{3}{*}{$\begin{array}{l}\text { England } \\
\text { France }\end{array}$} & Total & Small & $<2.9 \times 10^{14}$ & - \\
\hline & $50-100$ & $4.2 \times 10^{13}$ & $4.2 \times 10^{14}$ & - \\
\hline & $20-50$ & - & Small & - \\
\hline \multirow[t]{3}{*}{ Hungary } & $100-150$ & - & $0-4.2 \times 10^{13}$ & $0-8.4 \times 10^{13}$ \\
\hline & $50-100$ & $2.8-4.2 \times 10^{11}$ & $6.3-12.5 \times 10^{13}$ & $1.1-2.9 \times 10^{14}$ \\
\hline & $20-50$ & $1.5-2.5 \times 10^{13}$ & $3.1-5 \times 10^{13}$ & $5.9-8.4 \times 10^{13}$ \\
\hline \multirow[t]{4}{*}{ Iceland } & $150-200$ & $5.9 \times 10^{12}$ & $1.8 \times 10^{13}$ & $2.6 \times 10^{13}$ \\
\hline & $100-150$ & $1.3 \times 10^{13}$ & $2.9 \times 10^{13}$ & $5.0 \times 10^{13}$ \\
\hline & $50-100$ & $2.9 \times 10^{13}$ & $5.0 \times 10^{13}$ & $6.7 \times 10^{13}$ \\
\hline & $20-50$ & $1.0 \times 10^{12}$ & $2.0 \times 10^{12}$ & $4.0 \times 10^{12}$ \\
\hline Italy & Total & $3.3 \times 10^{12}$ & - & - \\
\hline Japan & Total & $2.7 \times 10^{14}$ & - & _ \\
\hline \multirow[t]{2}{*}{ Korea } & $50-100$ & $3.6 \times 10^{6}$ & - & - \\
\hline & $20-50$ & $2.1 \times 10^{6}$ & - & - \\
\hline Mexico & Total & $5.9 \times 10^{13}$ & - & - \\
\hline New Zealand & Total & $3.3 \times 10^{13}$ & $5.0 \times 10^{13}$ & - \\
\hline \multirow[t]{4}{*}{ Nicaragua } & $150-200$ & $<4.2 \times 10^{14}$ & $<4.2 \times 10^{14}$ & $4.2 \times 10^{14}$ \\
\hline & $100-150$ & $1.3 \times 10^{15}$ & $2.5 \times 10^{15}$ & $4.2 \times 10^{15}$ \\
\hline & $50-100$ & $<4.2 \times 10^{14}$ & $<4.2 \times 10^{14}$ & $4.2 \times 10^{14}$ \\
\hline & $20-50$ & - & - & - \\
\hline Spain & Total & $8.4 \times 10^{11}$ & $4.2 \times 10^{12}$ & - \\
\hline \multirow[t]{2}{*}{ Sweden } & $50-100$ & - & $2.1-4.2 \times 10^{13}$ & $6.3 \times 10^{13}$ \\
\hline & $20-50$ & - & $2.1 \times 10^{13}$ & $4.2 \times 10^{13}$ \\
\hline \multirow[t]{4}{*}{ Taiwan } & $150-200$ & $1.7 \times 10^{11}$ & $4.2 \times 10^{11}$ & $8.4 \times 10^{11}$ \\
\hline & $100-150$ & $8.4 \times 10^{10}$ & $2.1 \times 10^{11}$ & $8.4 \times 10^{11}$ \\
\hline & $50-100$ & $1.3 \times 10^{11}$ & $4.2 \times 10^{11}$ & $1.3 \times 10^{12}$ \\
\hline & $20-50$ & $4.2 \times 10^{10}$ & $2.1 \times 10^{11}$ & $4.2 \times 10^{11}$ \\
\hline Yugoslavia & Total & $5.0 \times 10^{12}$ & $2.1 \times 10^{13}$ & $4.2 \times 10^{13}$ \\
\hline United States & Total & $2.9 \times 10^{14}$ & $1.3-2.9 \times 10^{15}$ & $8.4-16.8 \times 10^{15}$ \\
\hline
\end{tabular}


Section 5

RECENT INTERNATIONAL DEVELOPMENTS

This section discusses the status of geothermal energy development in countries for which information is available from public documents or through responses to the questionnaire. It does not include estimates of the national geothermal resources calculated in Section 2, based on regional geology, volcanism, and other factors. Most of the data came from the responses to the questionnaire, al though much information was obtained from literature sources such as the Proceedings of the Second United Nations Symposium on the Development and Use of Geothermal Resources.

In keeping with the World Energy Conference classification, the countries have been grouped by major geographic region in the following order: North America, Central America, South America, Western Europe, Eastern Europe, Asia, East Africa, and Oceania.

NORTH AMER ICA

\section{Canada}

Geothermal development in Canada is in the preliminary stage and therefore does not provide sufficient information for a detailed assessment of the resource. Suffice it to say that the western part of Canada is in a geothermal region and it is therefore likely that intensive geothermal exploration will discover significant resources. At present, geothermal electric power capacity is estimated to reach $10 \mathrm{MW}$ by 1985 . Direct heat utilization would probably constitute the most important use of the resource in the near future, reaching perhaps $8.4 \times 10^{11} \mathrm{~J} / \mathrm{d}$ by 1985 . The estimated total resource base of geothermal energy to a depth of $3 \mathrm{~km}$ and above $15^{\circ} \mathrm{C}$ is $1.7 \times 10^{24} \mathrm{J.}^{*}$

\footnotetext{
${ }^{\star} \mathrm{All}$ estimates given in this section are based on the questionnaires and available reports as distinct from our own estimates. See Section 2, Assumption 5, for the definition of resource base.
} 
Mexico

A successful geothermal power plant of $75 \mathrm{MW}(\mathrm{e})$ capacity has been in operation at Cerro Prieto since November 1973. The plant is presently being expanded through additional drilling and construction work to achieve a capacity of $150 \mathrm{MW}$ in the near future. Informal estimates suggest that the Cerro Prieto field will support 500-1000 MW (e) capacity. Temperatures above $340^{\circ} \mathrm{C}$ nave been recorded in some of the holes drilled most recently.

Extensive exploration is taking place in many other areas of Mexico, especially at Ixtlan, Los Negritos, and Los Azufres. It is estimated by the Comisión Federal de Electricidad that 400-1400 MW of geothermal electricity would be on stream by 1985 and 1500-20,000 MW by the year 2000. The ultimate geothermal potential of Mexico is variously estimated at 4000-20,000 MW (e).

\section{United States}

The 1 argest geothermal power installations in the world at present are in the United States. By the end of 1976, 502 MW of installed electric capacity were in existence in the United States, all in The Geysers region of California. In that region a total geothermal power capacity of 2000-4000 MW is estimated to exist. The Geysers field is a high-quality vapor-dominated field that will increase in importance in years to come. The slow development of the field is primarily due to a variety of environmental and legal roadblocks.

Active exploration and drilling is presently going on in the United States in more than twenty separate areas (Figure 7). A major area of exploration is the Imperial Valley of California, just north of the successful geothermal power development at Cerro Prieto, Mexico. Four different geothermal fields have been discovered so far in the Imperial Valley: Niland, Brawley, Heber, and East Mesa. Estimates of the total geothermal capacity of the Imperial Valley for electric power production vary widely, ranging from 1500-20,000 MW (e) capacity. Severe salinity problems have been encountered in the Niland field near the Salton Sea, where dissolved solids concentrations of more than $25 \%$ have been encountered in a high-temperature field of large dimensions. The temperature range of the geothermal reservoirs encountered to date varies from $180^{\circ} \mathrm{C}$ in the Heber field up to $360^{\circ} \mathrm{C}$ in the $\mathrm{Nil}$ and field. 


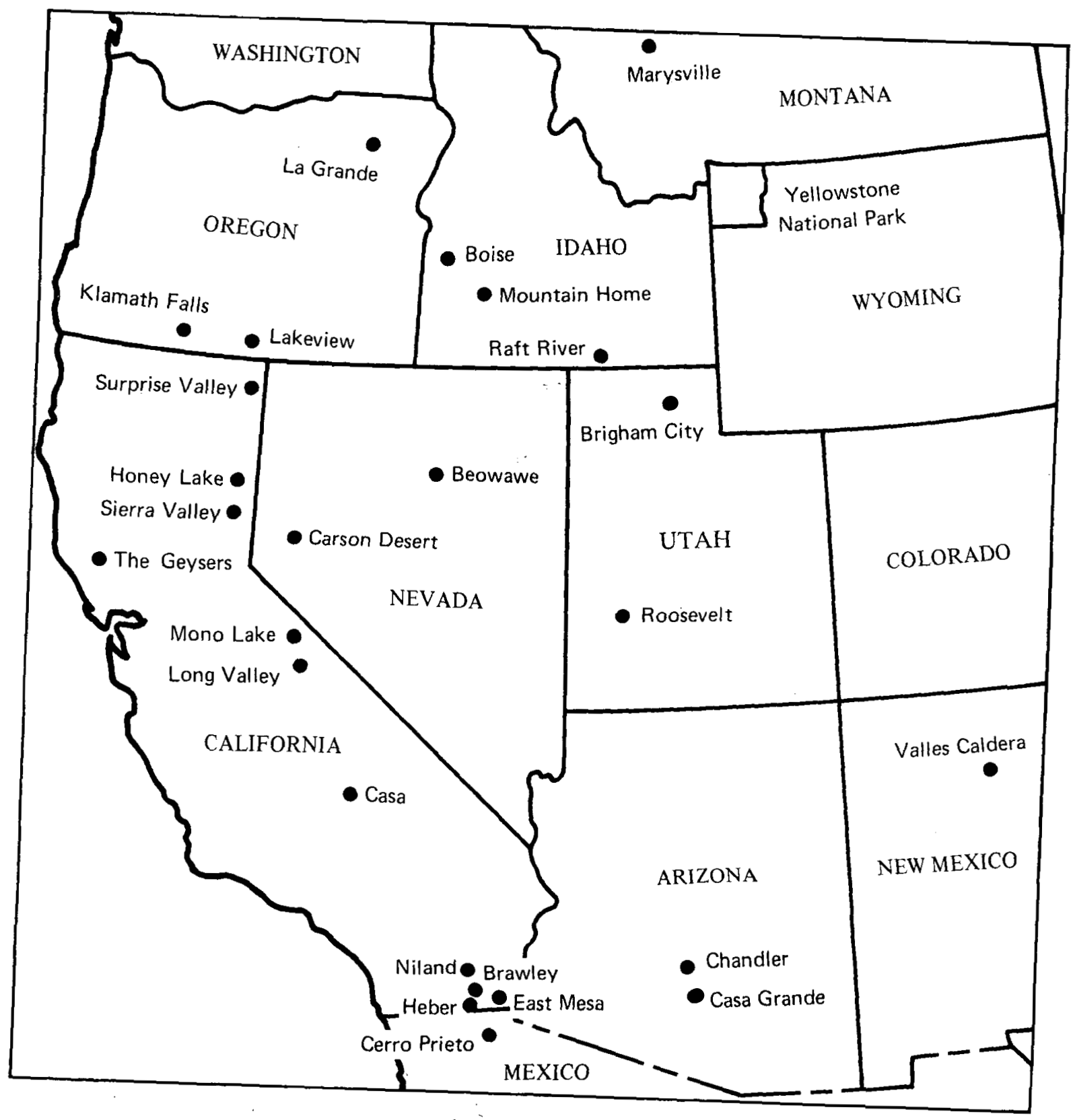

Figure 7 Locations of geothermal drilling in the United States and northern Mexico 
Successful discoveries have been reported in the Valles Caldera in New Mexico and the Roosevelt field in Utah. Both fields are reported to be nigh-temperature liquid-dominated geothermal reservoirs. It is informally estimated that the valles Caldera field will support at least $100 \mathrm{MW}$ (e) capacity. It is unknown as yet what the ultimate capacity of the Roosevelt field will be because only limited exploration has been completed. However, initial results have been encouraging inasmuch as one of the early exploration wells has produced a mass flow capable of supporting more than $15 \mathrm{MW}$ (e) capacity.

It is the goal of the Department of Energy (DOE) to achieve a minimum geothermal power capacity of $6000 \mathrm{MW}$ by 1985 and more than 20,000 MW of electricity by the year 2000. At the same time, considerable effort is being devoted to the study of direct heat uses since a large portion of the energy used in the United States is of the low-grade-heat type. The federal government, through DOE, will spend more than $\$ 50,000,000 / y r$ for the foreseeable future in an attempt to solve a variety of technical problems and stimulate private industry to explore and develop geothermal resources. As part of that effort, experiments are now being designed to exploit the geopressured resources of the Gulf coast for the production of mechanical-pressure energy, geothermal heat, and methane gas.

Space heating is being implemented successfully in Klamath Falls, Oregon, and in Boise, Idaho, as well as in many other localities. The growing shortage of natural gas in the United States will no doubt cause an increase in the use of low-grade geothermal heat for both space heating and other direct heat uses such as greenhouses. The U.S. Geological Survey has estimated the recoverable heat in the United States to be about $3.5 \times 10^{20} \mathrm{~J}$ of usable heat and up to $46,000 \mathrm{MW}$ cen of electric energy.

CENTRAL AMER ICA

\section{Costa Rica}

Active geothermal exploration is currently taking place in Costa Rica where the Las Pailas Hornillas area in the Guanacaste province is being investigated. Exploration drilling is scheduled to start by the end of 1977, and a geothermal power plant of $100 \mathrm{MW}$ capacity is to be installed in 1982-1984. 


\section{El Salvador}

Practically all of Central America is an intensely volcanic, highly active geothermal region. A 60-MW geothermal power plant has been in operation in the Ahuachapan field in El Salvador since 1976. That plant will soon be increased to $80 \mathrm{MW}$ capacity through the development of a secondary flash system. It is the intention of the national electric authority in EI Salvador (CEL) to develop at least $100 \mathrm{MW}$ additional capacity from geothermal resources by 1985 . Exploration efforts are currently proceeding at three promising geothermal fields:

Chinameca, Berlin, and San Vicente.

\section{Guatemala}

In Guatemala, the national electric company (INDE), with the assistance of some outside consultants, is currently proceeding with geothermal exploration at the Moyuta field. No success has been achieved to date in proving geothermal steam for commercial power production capacity. However, simultaneous exploration through outside technical assistance is presently taking place at the Zunil prospect, and it is also likely that the Amatitlan geothermal area will be subjected to a closer examination in 1977. The objective of the present exploration in Guatemala is to achieve a minimum $100 \mathrm{MW}$ capacity by the early $1980 \mathrm{~s}$.

\section{Honduras}

Honduras has just embarked on an aggressive geothermal exploration program. The national electric authority (ENEE) intends to explore two areas initially: the Pavana area near Choluteca in the southern part of the country and the San Ignacio area northwest of Tegucigalpa, the capital. The objective of that exploration program is to achieve a minimum of $50 \mathrm{MW}$ capacity by 1982 and $100 \mathrm{MW}$ by $1984-1985$.

\section{Nicaragua}

Geothermal exploration is currently proceeding in Nicaragua, where active drilling is taking place at the Volcan Momotombo field. Sixteen exploration and development holes have been drilled to date. At present, the productive capacity of the wells is uncertain because of conflicting reports about their success. The national electric authority (ENALUF) hopes to achieve a $100 \mathrm{MW}$ capacity from the Momotombo geothermal field by the early 1980s. It is estimated by ENALUF that 150-220 MW of geothermal power will be installed by $1985,300-400 \mathrm{MW}$ by 2000 , and up to $800 \mathrm{MW}$ by the year 2020. 


\section{Panama}

Only minimal geothermal exploration has been carried out in Panama. Some attractive possibilities seem to exist in the region of Cerro Pando and CalderaChiriqui province. It is not possible at present to make a judgment on the ultimate potential of geothermal energy development in Panama. However, because Panama is in a major geothermal belt, it is likely that economically attractive geothermal possibilities would materialize in the course of exploration. Some projections suggest a probable installed geothermal capacity of $60 \mathrm{MW}$ by 1985 .

\section{SOUTH AMERICA}

\section{Argentina}

Geothermal exploration in Argentina has just been started under the auspices of the National Secretariat of Energy in cooperation with the Argentina Commission on Geothermal Energy. Geothermal activity is concentrated along the boundaries of the Andes range in the vicinity of recent volcanic activity. The principal area of investigation at present is the Copahue area in the Neukuen province. Detailed exploration will indicate the nature and quality of the geothermal resources in that area. Other areas, such as the Bahia $B 1$ anca and Rosario de $1 \mathrm{a}$ Frontera, are known to have hot water systems. It is hoped that $20 \mathrm{MW}$ of geothermal power will be installed in the Copahue area by 1985. Only limited information about the ultimate potential of geothermal energy in Argentina is available.

Brazil

Geothermal exploration in Brazil has also just begun. At present there are at least 23 known hot springs, primarily in the state of Goias. There, two areas of not springs--the Serra das Caldas, a well-known not spring and resort area, and the Lagoa dos Peixes hot springs--indicate some potential and are presently being subjected to detailed investigation. Exploration is also planned for the regions of Bahia and Minas Gerais.

\section{Chile}

Exploration efforts in Chile, partially supported by the United Nations, have resulted in the discovery of the El Tatio geothermal field with a proven productive capacity of over $16 \mathrm{MW}$ at present. Other regions of Chile show similar potential, notably the Puchuldiza and Pollo Quere in northern Chile. 
Peru and Bolivia

No significant amount of geothermal exploration has been carried out as yet in Peru and Bolivia, but both countries are located in a region of active volcanism. Numerous hot springs and fumaroles are known to exist in these two countries. It is reported that discussions are under way between national authorities and some international organizations to assist in the exploration and development of geothermal resources.

\section{WESTERN EUROPE}

\section{France}

On the mainland, geothermal energy in France is likely to be used for direct heat purposes. In 1976 a geothermal heat installation near Paris provided heating for 10,000 apartments, resulting in an overall savings equivalent to 10,000 tons of petroleum. Other parts of France with the potential for geothermal heat applications include the Aquitaine Basin, Bresse, Limagne, and Al sace.

Extensive exloration of geothermal resources by the French government in Bouillante, Guadeloupe, have resulted in the discovery of a geothermal reservoir; it is expected that a small geothermal power plant of perhaps $10 \mathrm{MW}$ will be installed on that island in the near future. It is expected that by 1985 the geothermal power plant at Bouillante might reach a $25 \mathrm{MW}$ capacity. On the other hand, the direct heat utilization capacity in mainland France might reach $600-$ $1700 \mathrm{MW}(\mathrm{th})$ by 1985 .

\section{Greece}

Geothermal exploration has been conducted in different parts of Greece since 1970. The most promising areas are the Ionian Islands, with the most outstanding potential existing on the islands of Milos, Santorini, and Nisiros. Some potential appears to exist also on the island of Lesbos, and there are warm springs in the regions of the Sperchios graben, Sousaki, Methana, and others. Geothermal drilling began on the island of Milos in 1972, and deep test drilling was done there in 1975-1976. Two deep test holes encountered temperatures higher than $250^{\circ} \mathrm{C}$; however, both wells are reported to be characterized by relatively low flow rates. 
Iceland

The chief use of geothermal energy in Iceland at present is for direct heating of homes in Reykjavik, the capital of Iceland. More than $340 \mathrm{MW}(\mathrm{th})$ is presently being utilized for space heating in most of the homes in Reykjavik and neighboring towns. A small geothermal power plant is in operation at Namafjall, producing $2.5 \mathrm{MW}(\mathrm{e})$. A 50 -MW-capacity geothermal power plant is under construction at Krafla in an active volcanic zone. Subsequent to the start of construction the volcano became active, so the future of the power plant is somewhat uncertain at this moment.

It has been estimated that the high-temperature areas of Icel and have a production potential of $3200 \mathrm{MW}(\mathrm{th})$ for fifty years and that the heat content of recoverable low-temperature resources may amount to the equivalent of $4 \mathrm{Dillion}$ tons of petroleum. The estimated total capacity of geothermal electrical power in Iceland is expected to reach $150 \mathrm{MW}$ by $1985,500 \mathrm{MW}$ by 2000 , and perhaps as much as $800 \mathrm{MW}$ by the year 2020. The chief use of geothermal energy in Iceland, however, is currently in direct heating. At present the total installed nonelectric capacity is $3160 \mathrm{GWh} / \mathrm{yr}$. The level of use is expected to increase to $10,000 \mathrm{GWh} / \mathrm{yr}(\mathrm{th})$ by the year 2000 and to perhaps $15,000 \mathrm{GWh} / \mathrm{yr}$ by 2020 .

\section{$\underline{\text { Italy }}$}

As of the first quarter of 1975, the total installed geothermal electric capacity in Italy was about $420.6 \mathrm{MW}$, of which 380 was in the Larderello region, 15 at Travale, and 22 in the Monte Amiata region (Figure 8). Italy pioneered the development of geothermal energy in the world when the first electric power generator was established at Larderello early in the 1900s. It is likely that a considerably accelerated geothermal exploration and development program will be taking place in Italy within the next few years. The total direct neat utilization (nonelectric) in 1976 was estimated at $2.1 \times 10^{12} \mathrm{~J} / \mathrm{d}$. It has been estimated that the total geothermal power capacity in Italy might increase to perhaps 800 MW by 1985 and that direct heat utilization might increase by perhaps $60 \%$ over what it is at present. The total stored heat capacity in reservoirs of less than $100^{\circ} \mathrm{C}$ was estimated at $6.7 \times 10^{21} \mathrm{~J}$, and an approximately equivalent amount has been estimated for the reservoirs at a temperature range of $100-150^{\circ} \mathrm{C}$. 


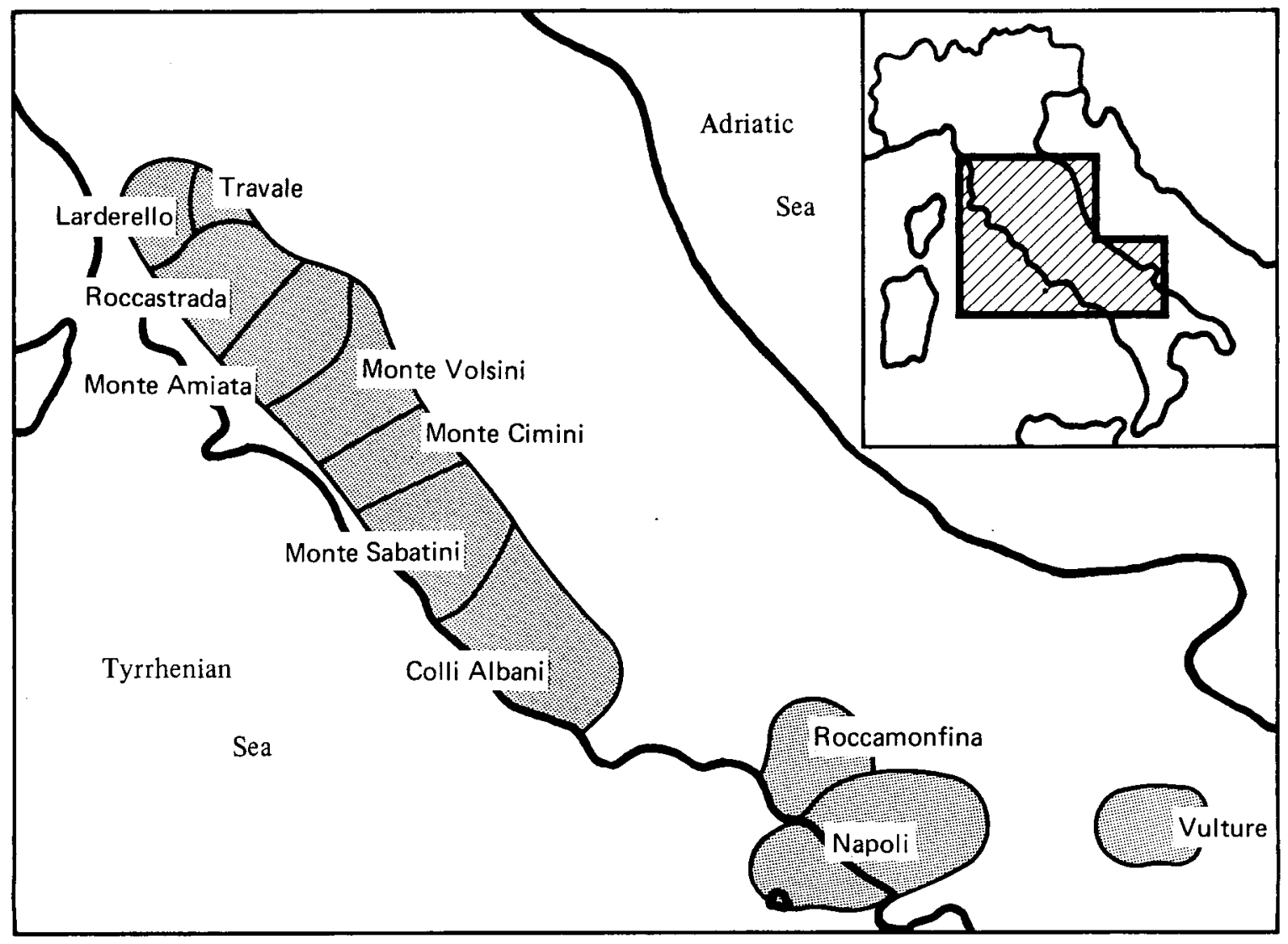

Figure 8 Geothermal regions of I taly 


\section{Portugal}

The chief exploration activity now taking place in Portugal is on the island of San Miguel in the Azores. There, geothermal exploration by the Institute of Geosciences, supported by an international contractor, is yielding initially promising results. Temperature gradients as high as $0.8^{\circ} \mathrm{C} / \mathrm{m}$ have been encountered in shallow test holes drilled in promising areas selected by prior geophysical investigations. The plans are to develop a 3-5 MW noncondensing geothermal power plant by 1978 . In case of success, the geothermal exploration and development activity would continue, with the ultimate objective of developing at least $30 \mathrm{MW}$ of geothermal electricity by the mid-1980s. Should a large geothermal reservoir be discovered, larger-scale development for industrial and other purposes might follow, with an ultimate objective of $100 \mathrm{Mw}$ or more by the year 2000.

Exploration in San Miguel is due to be followed in short order by exploration in the other islands, especially Terceira and Fayal. Exploration on the mainland of Portugal is under way, with the objective of developing hot water resources for nonelectric uses, mainly in the northern part of the country.

\section{Spain}

The main geothermal regions of Spain are located in the Canary Islands, especially at Lanzarote, where very high temperatures have been encountered at shallow depths. Intensive exploration is currentiy taking place at Lanzarote, with the objective of replacing the existing diesel power. Exploration in the mainland regions will revolve around the development of lower-grade geothermal resources for direct heating purposes. The objective of electric power development in Spain is to achieve a capacity of at least 25 MW (e) by 1985 and perhaps $200 \mathrm{MW}$ by the year 2000. While it is difficult to estimate the nonelectric demand, it may range from $10 \mathrm{MW}$ by 1985 up to $50 \mathrm{MW}$ by the year 2000.

\section{Sweden}

At present there is no utilization of geothermal energy in Sweden. However, ongoing geothermal resource investigations suggest that some use will be made of hot water for direct heat purposes. It is estimated that by the year $2000 \mathrm{a}$ total of $4.2-8.4 \times 10^{13} \mathrm{~J} / \mathrm{d}$ will be yielded from geothermal water for nonelectric purposes. The estimated total stored heat to a depth of $3 \mathrm{~km}$ in Sweden is $4.2 \times 10^{22} \mathrm{~J}$. 


\section{West Germany}

At present the only utilization of geothermal energy in West Germany is for nonelectric purposes. At Urach and Wiesbaden the total installed capacity for nonelectric purposes is approximately $4.5 \times 10^{13} \mathrm{~J} / \mathrm{d}$. The estimated total energy resource base of west Germany appears to be approximately $1.4 \times 10^{23} \mathrm{~J}$ to a depth of $3 \mathrm{~km}$. The known hot water reservoirs in West Germany occur in the Rhine graben basin, the northern Germany basin, and the southern Germany (Molasse) basin.

\section{United Kingdom}

The United Kingdom appears to be a region of normal temperature gradient (25$\left.30^{\circ} \mathrm{C} / \mathrm{km}\right)$, with a few anomalous regions where temperature gradients reach $40-$ $45^{\circ} \mathrm{C} / \mathrm{km}$ (in southwest England). In the North Sea Basin, thermal gradients appear to be higher, at times exceeding $40^{\circ} \mathrm{C} / \mathrm{km}$. Electric power production from geothermal resources appears to be practicable only if technology for extracting geothermal heat from hot dry rock becomes successful (i.e., at the turn of the century or later). It is further estimated that direct heat utilization of geothermal energy may reach as much as $2.9 \times 10^{14} \mathrm{~J} / \mathrm{d}$. The total resource base of geothermal energy to a depth of $3 \mathrm{~km}$ is estimated to be $5.4 \times 10^{22} \mathrm{~J}$ on 1 and and approximately $2.9 \times 10^{22} \mathrm{~J}$ in the North Sea Basin.

\section{EASTERN EUROPE}

\section{Hungary}

Geothermal energy harnessed for direct heat uses is probably at its most advanced stage in Hungary. Extensive utilization is presently being made of low and intermediate geothermal heat for space heating, greenhouse heating, and industrial uses. It is estimated that present total utilization capacity of geothermal heat in Hungary is approximately $3.9 \times 10^{13} \mathrm{~J} / \mathrm{d}$. Plans for further development suggest that the geotherinal heat utilization will increase to 4.2 $6.7 \times 10^{13} \mathrm{~J} / \mathrm{d}$ by $1985,9.2-25 \times 10^{13} \mathrm{~J} / \mathrm{d}$ by 2000 , and will ultimately reach as much as $1.7-4.6 \times 10^{14} \mathrm{~J} / \mathrm{d}$ by 2020 .

In 1975 more than 430 wells were drilled in Hungary, which produced water at temperatures greater than $35^{\circ} \mathrm{C}$ at the well head and were utilized for direct heat. These wells produced over $460 \mathrm{~m}^{3} / \mathrm{min}$ of geothermal fluid, yielding over $1000 \mathrm{MW}$ of thermal energy. The total usable heat in the recoverable water from the main reservoir in Hungary has Deen estimated to be $5 \times 10^{19} \mathrm{~J}$. 


\section{Soviet Union}

Electric power is being produced on a small scale in the Soviet Union, mainly in the Kamchatka Peninsula. Two small power plants, one in Pauzhetska (producing $5 \mathrm{MW}$ ) and another at Paratunka (0.7 MW) have been operating for several years. At present geothermal energy in the USSR is primarily used as direct heat, including space heating, greenhouse operation, and industrial uses. More than 28 geothermal fields are now in use. Soviet scientists have estimated the potential yield of thermal water in the temperature range of $40-250^{\circ} \mathrm{C}$ to be $22 \times 10^{6} \mathrm{~m}^{3} / \mathrm{d}$. The chief regions of geothermal exploration and development in the Soviet Union are in the Kuril Islands, Kamchatka, and the Caucasus belt. Some geothermal deposits appear to occur also in Siberia, Kazakhstan, and Middle Asia. It has been estimated that the hydrothermal deposits of Kamchatka alone have the capacity to support more than 350-500 MW (e) at present, although no specific plans for such utilization have been announced.

\section{Yugoslavia}

It is unknown whether any geothermal energy in Yugoslavia will be utilized for electric power production. However, it is assumed that geothermal heat will be used. The estimated utilization will be of the order of $5.0 \times 10^{12} \mathrm{~J} / \mathrm{d}$ by 1985 , about four times as much by 2000, and about eight times as much by 2020 . Not enough information is currently available in Yugoslavia on the potential of geothermal energy; however, reasonably steep temperature gradients of the order of $60^{\circ} \mathrm{C} / \mathrm{km}$ are known to exist. The estimated reserve of geothermal energy below $100^{\circ} \mathrm{C}$ is $6.6 \times 10^{20} \mathrm{~J}$.

\section{Otner Eastern European Countries}

Limited exploration and use have been made of geothermal resources for nonelectric uses in the rest of Eastern Europe. Geologic evidence suggests that the geothermal region of Hungary extends to Czechoslovakia and Rumania and that economically attractive temperatures may exist in regions of Austria as well. Some exploration in southwestern Poland suggests that temperatures up to $60^{\circ} \mathrm{C}$ may exist in depths of less than $1 \mathrm{~km}$. 
China

Exploration in China is under way in the Hinalayas, where 10 geothermal fields have been discovered to date. One of these, in the Ch'iang-T'ang region in the Tibetan highlands, will be developed to generate electric power in the near future. The recently discovered Ku-Tul geothermal well near the Bhutan border has led investigators to conclude that the magma is very close to the surface along the Himalaya Range and that the geothermal potential is likely to be very great.

India

Geothermal exploration has been concentrated primarily in the northern regions of India. Exploration in the Puga Valley in the upper Himalayas close to the northern border of the country has found temperatures as high as $135^{\circ} \mathrm{C}$ at a depth of less than $100 \mathrm{~m}$. Geochemical thermometry suggests that temperatures higher than $250^{\circ} \mathrm{C}$ may be encountered in deeper drilling in that region. Preliminary exploration in the Manikaran area suggests that reservoir temperatures of $200^{\circ} \mathrm{C}$ or higher may be encountered in this region. A series of intriguing hot springs runs along the entire northern and southern range of volcanic deposits in western India. At the northern end of that region, in the Cambay area, geopressured geothermal energy is likely to occur. There, in oil exploration wells, abnormally high wellhead pressures in excess of $100 \mathrm{~kg} / \mathrm{cm}^{2}$ have been encountered. A joint geothermal exploration program with the United Nations is now under way. It is likely to result in a rapid assessment of India's geothermal potential.

\section{$\underline{\text { Israel }}$}

Exploration for geothermal resources in Israel was started in 1974. The Geological Survey of Israel conducted numerous field mapping and geochemical studies to identify geothermal resources in the Jordan rift valley and to compile a general heat flow map of the country. The hot springs in the Sea of Galilee region reach a temperature of $72^{\circ} \mathrm{C}$. Chemical thermometry suggests that reservoir temperatures of at least $140^{\circ} \mathrm{C}$ may occur at depth in that region. Electrical resistivity surveys in the Jordan rift valley have detected a number of anomalously low resistivity areas that will be investigated more closely in the near future. Hydrogeological investigations of the central Negev region show that a warmer aquifer (approximately $40^{\circ} \mathrm{C}$ ) underlies much of that region. Plans are now afoot to tap those aquifers for direct heat uses (greenhouse operations). A geo- 
pressured system has been discovered in the Ashkelon region, but its pressure and temperature characteristics are not yet fully known. Hot springs in the Dead Sea region (Zohar and Ein Yesha) have been tapped for balneological purposes, and a thriving tourist industry is being developed around the springs. The Tiberius hot springs have been used since biblical times for therapeutic purposes and still have the remains of elaborate Roman spas.

Jordan

The outstanding geotherinal springs in Jordan are the Zerka Ma' in Springs on the east side of the Jordan rift valley near the Dead Sea. The surface temperature of the Zerka Ma'in thermal springs is of the order of $64^{\circ} \mathrm{C}$, and chemical thermometry suggests that reservoir temperatures may be higher than $180^{\circ} \mathrm{C}$. At present, a preliminary evaluation of the Jordan geothermal potential is being conducted by a United Nations expert.

\section{Turkey}

Exploration drilling in the kizildere field has resulted in the discovery of geothermal potential with a maximum temperature of approximately $207^{\circ} \mathrm{C}$. However, because of serious calcium carbonate scaling problems, the field has not yet been used for commercial production. Instead, the geothermal fluid is presently being used for a pilot greenhouse operation. Extensive exploration activity by the Mineral Research and Exploration Institute of Turkey (MTA) has identified many other geothermal regions in the country. The MTA has estimated that geothermal energy is likely to supply $10 \%$ of the total Turkish electric energy requirements by the year 2000. Exploration activities in the Seferinisar and Tuzla regions of western Turkey have discovered areas of promising potential for the production of electricity from geothermal energy. Exploration activities el sewhere have suggested that in the regions near Kizildere and Ankara, significant geothermal energy potential does exist. At present the geothermal electric capacity in Turkey is only $0.5 \mathrm{MW}$. However, the exploration plans are to achieve a production capacity of $400 \mathrm{MW}$ by 1985, $1000 \mathrm{MW}$ by 2000, and perhaps $1500 \mathrm{MW}$ by 2020 . These are maximal estimates; other estimates are somewhat more conservative. 


\section{EAST AFRICA}

\section{Etniopia}

An active geothermal belt runs through the rift valley of eastern Africa, starting from the Red Sea to the north and continuing southward through the length of Ethiopia, Kenya, and Tanzania. Active volcanisin is currently taking place in the Afar rift valley of northern Ethiopia, where the Erta-'Ale volcano has been boiling at $1000^{\circ} \mathrm{C}$ or more for over a century. It has been estimated that the amount of continuous heat flow necessary to keep the Erta-'Ale lava pool at its current temperature is equivalent to that of a $100-M W$ power plant at full capacity.

Three separate regions have been identified as potentially promising. The most attractive region for geothermal development appears to be the Danakil depression. In that region the Tendaho area seems to be particularly attractive, with geotechnical evidence suggesting the occurrence of nigh-temperature, lowsalinity geothermal fields.

A number of favorable locations have been identified in the northern Afars area. At Dallol, geothermal springs with temperatures as high as $114^{\circ} \mathrm{C}$ at the surface have been measured. However, the problem confronting geothermal energy development in the Dallol area (other than the political instability of the area) is the very high salinity of the geothermal fluids. At present most of the geothermal exploration is centered on the lakes district north of Addis Ababa. Through a United Nations survey, a number of favorable geothermal prospects have been identified near Lake Langano and farther south.

The overall potential of geothermal energy in Ethiopia has been estimated from several thousand to perhaps as much as $20 \mathrm{GW}$. However, because of the small power demand in the country, the problem of developing high-quality geothermal resources, such as those at Tendaho, is associated with the cost of transinission from the remote prospect locations to the main grid of the country, sometimes more than $300 \mathrm{~km}$ away. Political factors have al so caused a slowdown in developing the outstanding geothermal resources of the country. Therefore geothermal energy utilization has been restricted to minor balneological uses. However, there is no doubt that geothermal energy will eventually provide an important source of electricity in Ethiopia. 


\section{French Territory of the Afars and the Issas}

Geothermal exploration in the region near $\mathrm{Dj}$ ibouti has encountered high geothermal reservoir temperatures (over $250^{\circ} \mathrm{C}$ at $1050 \mathrm{~m}$ ); but because of the high salinity of the fluids, their utilization is fraught with problems.

\section{Kenya}

The geothermal exploration and development in Kenya is farther ahead than Ethiopia's. A successful exploration program at the 01 karia field about $50 \mathrm{~km}$ north of Nairobi has demonstrated the existence of a high-quality, low-salinity geothermal reservoir. Temperatures of up to $287^{\circ} \mathrm{C}$ have been encountered in drill holes less than $1.5 \mathrm{~km}$ deep. Further development drilling is due to take place at 0lkaria, and exploration drilling is likely to take place in the near future in the Lake Hannington area to the north. Geophysical measurements of a third prospect, the Eburu Crater, have shown promising results.

The minimum installed capacity estimated by the East African Power and Lighting Company is $30 \mathrm{MW}$ of electric power by $1985,60-90 \mathrm{MW}$ by 2000 , and $90-150 \mathrm{MW}$ by 2020. The stored energy in the 0lkaria field has been estimated at 84 GW yr (gigawatt-years), of which $5 \%$ could be converted into electric energy.

\section{Other East African Countries}

Moderate exploration of the geothermal resources of Tanzania and Uganda has been carried out. On the basis of the limited exploration to date, it is too early to determine the ultimate potential of geothermal energy in those countries. Similarly, several geothermal indicators exist in Malawi and Burundi, but very little useful data are available to assess their commercial viability.

\section{OCEANIA}

\section{Fiji}

A number of hot springs, some at boiling point, suggest that geothermal potential may exist on Vanua Levu, the north island of Fiji. However, chemical thermometry indicates the base temperature of the reservoir to be quite $10 \mathrm{w}$, of the order of $140^{\circ} \mathrm{C}$. There are no immediate plans for development. 


\section{Indonesia}

Indonesia is located along a major geothermal belt and is characterized by extensive volcanism and earthquake activity, common indicators of geothermal resources in the area. Extensive investigations of geothermal energy have been carried out at Java, Bali, and some other islands by the Geological Survey of Indonesia, by the PLN (the national electric authority), and by Petromina (the national oil company). In addition, technical assistance for the exploraton of geothermal energy has been given by the governments of the United States and New Zealand. A 1927 exploration in the Kawah Kamojang near Bandung discovered that geothermal steam may be encountered at a very shallow depth. Renewed interest in the area spurred further exploration in 1973, with the assistance of the New Zeal and government. As of May 1975, four holes had been drilled to depths of 500-800 $\mathrm{m}$, and at least two have indicated the occurrence of dry steam underground. A small geothermal power plant is now being considered for the area, probably $15 \mathrm{MW}$ initially.

The Dieng Plateau of central Java was investigated in the early 1970 s by the Indonesia Power Research Institute with the assistance of the United States. Geophysical, geochemical, and drilling activities indicated the existence of a large, shallow geothermal system of the liquid-dominated type. Technical assistance missions by the United Nations and UNESCO have shown that many other geothermal areas in Java, such as Kawah Cibureum and Cisolok, are likely to be of interest. Informal estimates suggest that perhaps 20,000 MW of electric energy capacity occur in Java and as much as $60,000 \mathrm{MW}$ in all of Indonesia.

The estimated minimum installed geothermal energy capacity in Indonesia will be 30-100 MW in 1985 and 500-6000 MW by the year 2000 .

Japan

Japan witnessed a relatively slow growth of geothermal energy utilization for electric power production until the 1973 energy crisis. Prior to that only two electric generating plants using geothermal energy were in operation, in Matsukawa (22 MW) and 0take (13 MW). In 1976 the total installed geothermal power capacity in Japan was $68 \mathrm{MW}$. The energy crisis has stimulated the expansion of geothermal energy exploration. As a result it is anticipated that by the end of 1977 the installed geothermal power capacity will approach $150 \mathrm{MW}$ (based upon the completion of a 50-MW power plant at Takinoue and the completion of a 50-MW plant at Hatchobaru). The current objective is to achieve an 
installed geothermal electric capacity of $1000 \mathrm{MW}$ or more by 1982 and about $2000 \mathrm{MW}$ by 1985 . In addition, ambitious geothermal investigations are currently taking place in Japan, with the goal of establishing as much as 50,000 MW electric capacity by the turn of the century.

More than 10,000 hot springs are known to exist in Japan. In the past they nave been used primarily for balneological and religious purposes, with some minor uses such as fish breeding. Figure 9 shows the major regions of geothermal exploration in Japan at present. Approximately $2.5 \times 10^{14} \mathrm{~J} / \mathrm{d}$ are now being used for direct heat (nonelectric). The total geothermal energy resource of Japan, to a depth of $3 \mathrm{~km}$, is estimated at $1.2 \times 10^{21} \mathrm{~J}$.

\section{New Zealand}

The presently installed geothermal plant at Wairakei has a capacity of about $190 \mathrm{MW}$ (e). At Kawerau, geothermal energy is being used for the combined power production and direct heat needs of the Tasman Pulp and Paper Mi11. In addition, geothermal energy is extensively used at Rotorua for space heating and, in one case, for air conditioning. A second geothermal field at Broadlands, to be cormissioned in the early 1980s, is likely to be developed for power production, with an estimated capacity of approximately $150 \mathrm{MW}$. The total estimated geothermal power capacity of New Zeal and is rated at approximately $2000 \mathrm{MW}$ (e). It is estimated that $400 \mathrm{MW}$ of geothermal electricity will be on stream by 1985 , $1400 \mathrm{MW}$ by the year 2000, and $2000 \mathrm{MW}$ by the year 2020. The extent of direct heat utilization in New Zealand is expected to rise from $3.3 \times 10^{13} \mathrm{~J} / \mathrm{d}$ in 1985 to about $5.0 \times 10^{13} \mathrm{~J}$ by the year 2000 . The total resource base of geothermal energy in the explored areas of New Zealand is estimated to be $1.3 \times 10^{20} \mathrm{~J}$.

\section{The Philippines}

Extensive geothermal exploration has been taking place in the Philippines at the Tiwi, Leyte, and Los Banos areas. Successful exploration at Tiwi in southeastern Luzon has proved that sufficient geothermal steam exists for generating $100 \mathrm{MW}$ electric power. The first 100-MW electric plant will be installed in 1977, to de followed shortly by another 100-MW plant in the same area. Promising exploration in the Los Banos area suggests that geothermal power may be developed there in a relatively short time. Plans in 1976 called for the installation of $300 \mathrm{MW}$ of geothermal electricity by 1985 . These plans are presently under review with the intent of increasing the number. 


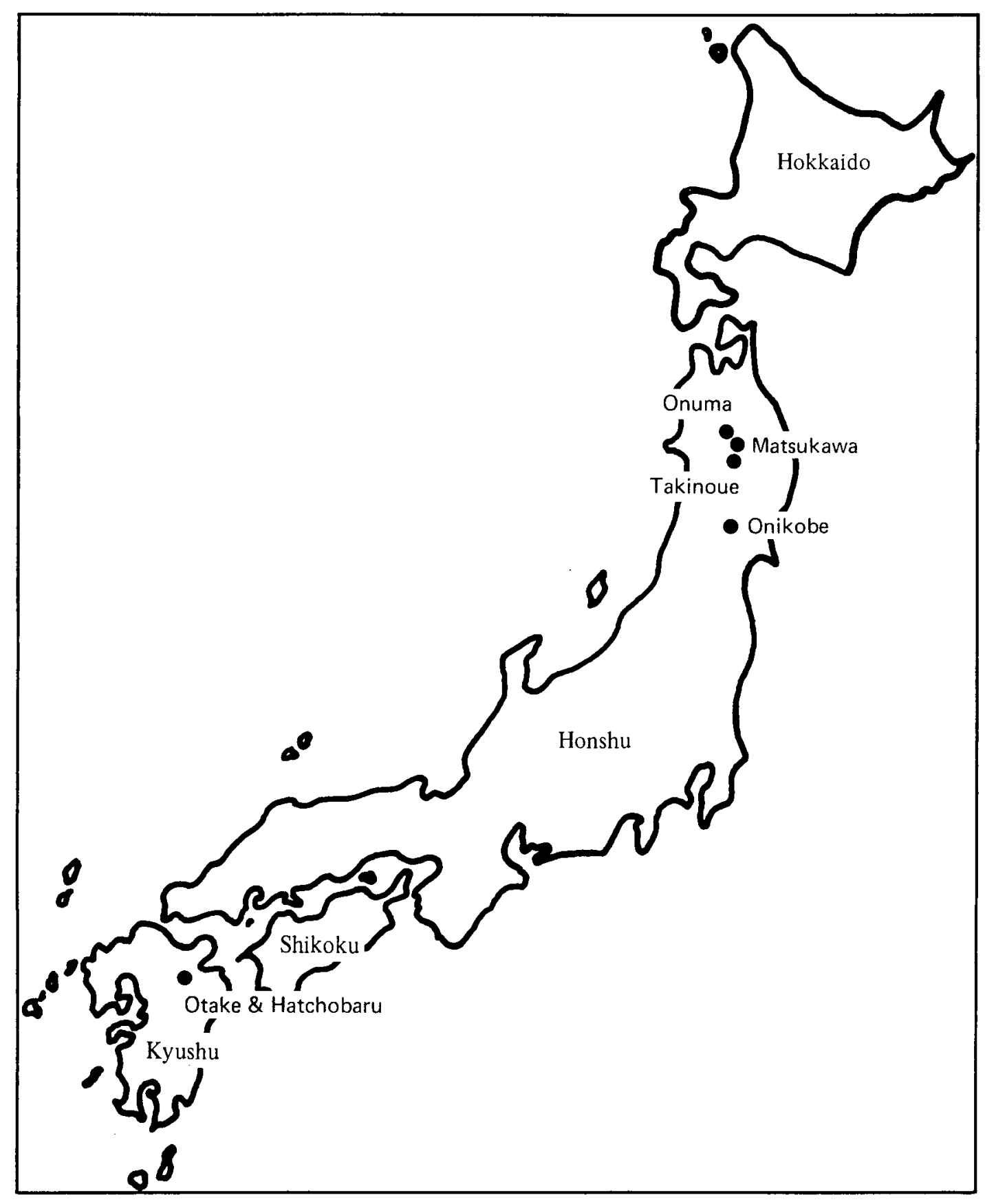

Figure 9 Major geothermal areas of Japan

5-19 


\section{Taiwan}

No geothermal power plants are in operation in Taiwan, though significant geothermal potential does exist in the country. High-temperature reservoirs have been encountered in both the Tatun and Tuchang areas. In the Tatun area, temperatures are as high as $293^{\circ} \mathrm{C}$, but because of the exceptionally high acidity of the water, no development was considered to be possible in that field. Current plans call for the development of $50 \mathrm{MW}$ geothermal capacity by $1985,200 \mathrm{MW}$ by 2000 , and perhaps $500 \mathrm{MW}$ by 2020 . The expected total capacity of direct heat utilization in Taiwan is $4.2 \times 10^{11} \mathrm{~J} / \mathrm{d}$ by 1985 , three times as much by 2000 , and five times as much by 2020 . 
Section 6

ENVIRONMENTAL CONSIDERATIONS

Geothermal energy promises to be less detrimental to the environment than energy derived from other sources; however, it is not environmentaliy benign and special consideration must be given to certain unique sets of possible problems. The amount of environimental control necessary will vary from country to country and region to region, depending on local air and water quality standards, on the characteristics of each geothermal reservoir, and to some extent on the power conversion process, whether it be flashed steam or some form of closed loop with reinjection.

Currently producing geothermal fields were developed with only the most rudimentary environmental controls, and several areas of concern have been identified as society has grown more environmentally aware. Not all fields will pose the same problems. A few of the more important considerations are as follows:

Waste brine disposal: If the geothermal fluid is partially or totally brine, the waste brine must be disposed of in a manner that will protect groundwater supplies needed for agricultural, domestic, or industrial uses. The methods of disposal thus far have consisted of surface streams, ponding and evaporation, and reinjection of the brine back into the reservoir. In some cases reinjection may be the preferred method, if there is a need to minimize ground subsidence or to replace the water in the reservoir to enhance production.

Noncondensible gases: Hydrogen sulfide and other noncondensible gases may affect air quality if the concentrations are sufficiently high and if they are vented to the atmosphere. Hydrogen sulfide appears to be the major offender, and present research is focusing on a solution to this problem. In some cases, the hydrogen sulfide concentration is so low that special controls may not be necessary. In others, stack disposal may suffice; and in some, sophisticated technology may be needed, depending on local factors. 
Waste heat rejection: Geothermal power plants are less efficient than fossil fuel plants; roughly two to three times more heat must be rejected per unit of power. Where fresh water is in abundant supply, this may not be a problem, but in arid regions cooling water may be at a premium and could slow geothermal development unless suitable alternatives are available. One solution, if the plant is operated as a flashed steam facility, is simply to use the geothermal steam condensate as makeup water in the cooling tower. This approach could pose problems if the temperature of the resource is low and if binary cycles are used in which no steam is produced. It could also pose a problem where reinjection of all the fluids is desired. Some combination of alternative approaches may prove to be the best solution in the long run.

Subsidence: Withdrawal of fluids may result in subsidence if measures are not taken to minimize the effect. Some areas, such as low coastal zones, populated areas, and agricultural irrigation systems, may be especially sensitive to subsidence.

Noise: Vented wells or steam lines can create excessive noise. Muffler systems may be needed in noise-sensitive areas.

Other considerations: Toxic trace elements (such as arsenic and mercury), land use, cooling tower effluents, and seismicity may require consideration when assessing the environmental impact. However, these aspects appear to pose only minor problems.

Present environmental control technology will probably serve the geothermal industry's needs in the near term, and work is progressing on improved technology, particularly for the control of hydrogen sulfide emissions. 


\section{Section 7 \\ B IBLIOGRAPHY}

Armstead, H. C., ed. Geothermal Energy: Review of Research and Development. Earth Science Series No. 12. Paris: UNESCO, 1973.

Barnea, J. "Multipurpose Exploration and Development of Geothermal Resources." Natural Resources Forum 1. New York: United Nations, 1971.

Bodvarsson, G. "Utilization of Geothermal Energy for Heating Purposes and Combined Schemes Involving Power Generation, Heating and/ or By-Products." In Proceedings, United Nations Conference on New Sources of Energy, Rome, 1961. Paper GR/5(G). New York: United Nations, 1964.

Boldizsar, T. "Geothermal Energy Use in Hungary." In Proceedings, International Conference on Geothermal Energy for Industrial, Agricultural and Commercial-Residential Uses. Klamath Falls, Oreg.: Oregon Institute of Technology, 1974.

Burrows, W. "Utilization of Geothermal Energy in Rotorua, New Zealand." In Proceedings, International Conference on Geothermal Energy for Industrial, Agricultural and Commercial-Residential Uses. Klamath Falls, Oreg.: Oregon Institute of Technology, 1974.

Einarsson, S. S. "Geothermal District Heating." Geothermal Energy: Review of Research and Development. United Nations Education, Scientific and Cultural office. Paris: UNESCO, 1973.

Gogue1, J. Geothermics. New York: McGraw-Hi11, 1976.

Head, J. "Geothermal Energy for Greenhouse Heating." Ore Bin, Vo1. 32, No. 9 (1970), pp. 182-183. 
Howard, J. H., ed. "Present Status and Future Prospects for Nonelectrical Uses of Geothermal Resources." UCRL 61926. Lawrence Livermore Laboratory, 1975.

Index to the Geothermal Fields of Japan. Agency of Natural Resources and Energy and Geological Survey of Japan, Ministry of International Trade and Industry, 1976.

Kerr, R. N., R. Bangma, W. L. Cooke, F. G. Furness, and G. Vamos. "Recent Developments in New Zealand in the Utilization of Geothermal Energy for Heating Purposes." In Proceedings, United Nations Conference on New Sources of Energy, Rome, 1961. New York: United Nations, 1964.

Kruger, P., and C. Otte, eds. Geothermal Energy: Resources, Production, Stimulation. Stanford, Calif.: Stanford University Press, 1973.

Lenzi, D. "Utilization de l'energie geothermique pour la production de l'acide boriquet et des sous-produits contenus dans les 'souffione'." In Proceedings, United Nations Conference on New Sources of Energy, Rome, 1961. Paper G/59. New York: United Nations, 1964.

Lindal, B. (1961a) "Geothermal Heating for Industrial Purposes in Iceland." In Proceedings, United Nations Conference on New Sources of Energy, Rome, 1961. New York: United Nations, 1964.

Lindal, B. (1961b) "The Extraction of Salt from Seawater by Multiple Effect Evaporators Using Natural Steam." In Proceedings, United Nations Conference on New Sources of Energy, Rome, 1961. New York: United Nations, 1964.

Lindal, B. "Industrial and Other Applications of Geothermal Energy." Geothermal Energy: Review of Research and Development. LC No. 72-97138. Paris: UNESCO, 1973.

Ludviksson, v. The Application of Natural Heat. The National Research Council of Iceland, Report 70-3. Reykjavik, 1970. (In Icelandic) 
Lund, J., G. Culver, and L. Svanevik. "Utilization of Geothermal Energy in Klamath Falls." In Proceedings, International Conference on Geothermal Energy for Industrial, Agricultural and CommercialResidential Uses. Klamath Falls, Oreg.: Oregon Institute of Technology, 1974.

Matthiasson, M. "Beneficial Uses of Heat In Iceland." In Proceedings, Conference on Beneficial Uses of Thermal Discharges. Albany, N.Y.: New York State Department of Environmental Conservation, 1970.

Mazzoni, A. "The Steam Vents of Tuscany and the Lardere110 Plant." Amonina Arts Grafiche, Bologna, 1948. (In English)

Milora, S. L., and J.W. Tester. Geothermal Energy As a Source of Electric Power. Cambridge, Mass.: M.I.T. Press, 1976.

Muffler, L. J. P. "Geothermal Resources." U.S. Mineral Resources. USGS Paper No. 820. 1973.

Rex, R. W. "Investigation of the Geothermal Potential of the Lower Colorado River Basin, Phase 1--The Imperial Valley Project." Institute of Geophysical Planetary Physics. University of California, Riverside, 1968.

Rex, R. W. "Geothermal Resources in the Imperial Valley." In California Water--A Study in Resource Management, edited by

D. Seckler. Berkeley: University of California Press, 1971.

The Times Atlas of the World. Comprehensive Edition. Edinburgh: The Times of London and John Bartholemew \& Son, Ltd., 1974.

UNESCO. Geothermics. United Nations Symposium on the Development and Utilization of Geothermal Resources, Pisa, 1970. Special Issue No. 2, Vol. 2 .

U.S. Energy Research and Development Administration. "A National Plan for Energy Research, Development and Demonstration: Creating Energy Choices for the Future." Vols. 1-2, ERDA 76-1, 1976. 
Valfells, A., B. Lindal, and V. Ludviksson. An Estimate of Heavy Water Manufacturing Costs in Iceland. Reykjavik: Iceland National Research Council, 1969.

Wahl, E. F. Geothermal Energy Utilization. New York: J. Wiley, 1977.

Wells, M. "Early Development of Western Geothermal Resources." Journal of the West. Vol. X, No. 1 (1971), pp. 53-71.

Zoega, J. "The Reykjavik Municipal Heating System." In Proceedings, International Conference on Geothermal Energy for Industrial, Agricultural and Commercial-Residential Uses. Klamath Falls, Oreg.: Oregon Institute of Technology, 1974. 